Cite this: Dalton Trans., 2014, 43, 7868

Received 19th December 2013, Accepted 7th March 2014

DOI: $10.1039 / \mathrm{c} 3 \mathrm{dt} 53535 \mathrm{e}$ www.rsc.org/dalton

\section{Porphyrins with a carbosilane dendrimer periphery as synthetic components for supramolecular self- assembly $\dagger$}

\author{
Zakariyya Ishtaiwi, ${ }^{a}$ Tobias Rüffer, ${ }^{a}$ Sami Klaib, ${ }^{b}$ Roy Buschbeck, ${ }^{a}$ Bernhard Walfort ${ }^{a}$ \\ and Heinrich Lang*a
}

The preparation of the shape-persistent carbosilane-functionalized porphyrins $\mathrm{H}_{2} \mathrm{TPP}\left(4-\mathrm{SiRR}^{\prime} \mathrm{Me}\right)_{4}, \mathrm{Zn}\left({ }^{\prime \prime}\right)$ $\operatorname{TPP}\left(4-\mathrm{SiRR}^{\prime} \mathrm{Me}\right)_{4} \quad\left(\mathrm{R}=\mathrm{R}^{\prime}=\mathrm{Me}, \mathrm{CH}_{2} \mathrm{CH}=\mathrm{CH}_{2}, \mathrm{CH}_{2} \mathrm{CH}_{2} \mathrm{CH}_{2} \mathrm{OH} ; \mathrm{R}=\mathrm{Me}, \mathrm{R}^{\prime}=\mathrm{CH}_{2} \mathrm{CH}=\mathrm{CH}_{2}\right.$, $\mathrm{CH}_{2} \mathrm{CH}_{2} \mathrm{CH}_{2} \mathrm{OH}$; TPP = tetraphenyl porphyrin), $\mathrm{H}_{2} \mathrm{TPP}\left(4-\mathrm{Si}_{(}\left(\mathrm{C}_{6} \mathrm{H}_{4}-1,4-\mathrm{SiRR}^{\prime} \mathrm{Me}\right)_{3}\right)_{4}$, and $\mathrm{Zn}(I I)-\mathrm{TPP}(4-\mathrm{Si}-$ $\left.\left(\mathrm{C}_{6} \mathrm{H}_{4}-1,4-\mathrm{SiRR}^{\prime} \mathrm{Me}\right)_{3}\right)_{4}\left(\mathrm{R}=\mathrm{R}^{\prime}=\mathrm{Me}, \mathrm{CH}_{2} \mathrm{CH}=\mathrm{CH}_{2} ; \mathrm{R}=\mathrm{Me}, \mathrm{R}^{\prime}=\mathrm{CH}_{2} \mathrm{CH}=\mathrm{CH}_{2}\right)$ using the Lindsey condensation methodology is described. For a series of five samples their structures in the solid state were determined by single crystal $X$-ray structure analysis. The appropriate $0^{\text {th }}$ and $1^{\text {st }}$ generation porphyrin-based 1,4-phenylene carbosilanes form 2D and 3D supramolecular network structures, primarily controlled by either $\pi-\pi$ interactions (between pyrrole units and neighboring phenylene rings) or directional molecular hydrogen recognition and zinc-oxygen bond formation in the appropriate hydroxyl-functionalized molecules. UV-Vis spectroscopic studies were carried out in order to analyze the effect of the dendritic branches on the optical properties of the porphyrin ring.

\section{Introduction}

Highly branched macromolecular architectures as well as selfassembly processes have become very popular and represent fascinating research areas both in natural sciences and engineering. ${ }^{1}$ In this respect, dendrimers and metallo-dendrimers, repetitive branched molecules of structural perfection, have attracted considerable attention as nanoscale molecular materials due to their novel properties. ${ }^{2}$ Dendrimers possess a three-dimensional and well-designed highly symmetric spherical arrangement with flexible structures employing isotropic

\footnotetext{
${ }^{a}$ Technische Universität Chemnitz, Faculty of Natural Sciences,

Institute of Chemistry, Inorganic Chemistry, D-09107 Chemnitz, Germany.

E-mail: heinrich.lang@chemie.tu-chemnitz.de; Fax: +49-(0)371-531-21219;

Tel: +49-(0)371-531-21210

${ }^{b}$ Tafila Technical University, Faculty of Science, Department of Chemistry and Chemical Technology, Tafila, Jordan

$\dagger$ Electronic supplementary information (ESI) available: X-ray crystal structure data. Fig. S1/S2 and Fig. S3 display the crystal structure of 3c and 6a, respectively, with respect to the orientation of the unit cell. Table $\mathrm{S} 1$ gives crystal and intensity collection data of $\mathbf{3 b} \cdot \mathbf{1} / \mathbf{4} \mathrm{CH}_{2} \mathrm{Cl}_{2}, 3 \mathbf{c}, \mathbf{4 a}, \mathbf{6 a} \cdot \mathbf{2 t h f}$ and $\mathbf{9 b} \cdot \mathbf{3 . 5 E t O H}$. Fig. S4-S6 illustrate T-shaped $\pi-\pi$ interactions in the crystal structure of $9 \mathbf{b} \cdot \mathbf{3 . 5 E t O H}$. Table S2 gives selected geometric features of intermolecular hydrogen bonds of 6a. Table S3 gives structural parameters of the porphyrin cores of $3 \mathbf{b}, 3 \mathbf{c}, \mathbf{4 a}, \mathbf{6 a}$ and 9b. Fig. S7 illustrates geometrical features of saddling distorted porphyrins. Fig. S8 shows the atom labelling for the NMR data. CCDC 976300-976304. For ESI and crystallographic data in CIF or other electronic format see DOI: 10.1039/ c3dt53535e
}

assembling processes. $^{3}$ In the past, also snowflake-shaped dendrimers containing rigid backbones within the dendrimer side chains were prepared. ${ }^{4}$ Such systems were used, for example, as mediators in electron-transfer and energy-transfer processes, ${ }^{5}$ as dendritic boxes ${ }^{6}$ or as drug carrier systems. ${ }^{7}$

Porphyrins can successfully be used as core molecules, as branching units, or, for example, in the stepwise synthesis of cross-shaped covalent assemblies. ${ }^{8}$ The micro-environments set-up by such molecules can be used among others to tune and control both optical and electrochemical properties of the appropriate porphyrin building block. ${ }^{8,9}$ Out of this, porphyrins are very useful molecules to probe and hence to characterize dendritic local environments. Recently, metallo-porphyrins tailored at a dendrimer core have been developed as synthetic models to mimic naturally occurring systems including lightharvesting and electron transfer processes (i.e., chlorophyll $),{ }^{8 b, 10}$ molecular oxygen storage and transport phenomena (i.e., hemoglobin) as well as oxidation enzymes (i.e., cytochrome $c) .{ }^{11,12}$ In such systems, the porphyrin building blocks have site isolation effects imposed by the dendritic shell. This makes it possible to utilize such species in diverse applications including homogeneous catalysis, ${ }^{13}$ drug delivery ${ }^{14}$ and singlet oxygen generation. ${ }^{11 a, 14 b, 15}$ In addition, these compounds can be applied as non-linear optical, ${ }^{16}$ and light-emitting ${ }^{17}$ materials, as molecular sensors ${ }^{18}$ or photo-active systems which can be considered as artificial antennae devoted to solar energy conversion. ${ }^{19}$ 
Recently, we got interested in the synthesis of $\mathrm{SiCH}_{2} \mathrm{CH}=\mathrm{CH}_{2^{-}}$and $\mathrm{Si}\left(\mathrm{CH}_{2}\right)_{3} \mathrm{OH}$-functionalized tetraphenyl porphyrins and to use them as supramolecular tectons in the formation of ordered network arrays, since this family of compounds provides a relatively unexplored class of molecules due to their large size, ease of preparation and, for example, excellent coordination ability. Out of these reasons, we here report the Lindsey condensation methodology for the preparation of novel $0^{\text {th }}$ and $1^{\text {st }}$ generation 1,4-phenylene-based carbosilane dendrimer-functionalized porphyrins and zinc(II)-porphyrins. The single-crystal X-ray structure determination of five samples is reported as well showing different interporphyrin interactions.

\section{Results and discussion}

\section{Synthesis}

For the preparation of the carbosilane dendrimer-based porphyrins 3a-c (Scheme 1) the synthetic methodology developed by Lindsey was used. ${ }^{20}$ In this respect, the carbosilane aldehydes $\mathrm{H}(\mathrm{O}) \mathrm{C}-1-\mathrm{C}_{6} \mathrm{H}_{4}-4-\mathrm{SiRR}^{\prime} \mathrm{Me}\left(\mathbf{2 a}, \mathrm{R}=\mathrm{R}^{\prime}=\mathrm{Me} ; \mathbf{2 b}, \mathrm{R}=\mathrm{Me}\right.$, $\mathrm{R}^{\prime}=\mathrm{CH}_{2} \mathrm{CH}=\mathrm{CH}_{2} ; 2 \mathrm{c}, \mathrm{R}=\mathrm{R}^{\prime}=\mathrm{CH}_{2} \mathrm{CH}=\mathrm{CH}_{2}$ ), accessible by the consecutive treatment of $1-\mathrm{Br}-\mathrm{C}_{6} \mathrm{H}_{4}-4-\operatorname{SiRR}^{\prime} \mathrm{Me}\left(1 \mathrm{a}, \mathrm{R}=\mathrm{R}^{\prime}=\right.$ Me; 1b, R = Me, $\mathrm{R}^{\prime}=\mathrm{CH}_{2} \mathrm{CH}=\mathrm{CH}_{2} ; \mathbf{1 c}, \mathrm{R}=\mathrm{R}^{\prime}=\mathrm{CH}_{2} \mathrm{CH}=\mathrm{CH}_{2}$ ) with ${ }^{t} \mathrm{BuLi}$ and dimethylformamide, were reacted with pyrrole in the presence of catalytic amounts of $\left[\mathrm{BF}_{3} \cdot \mathrm{OEt}_{2}\right]$ followed by addition of 2,3-dichloro-5,6-dicyanobenzoquinone (= DDQ) in $\mathrm{CH}_{2} \mathrm{Cl}_{2}$ solutions at ambient temperature (Scheme 1, Experimental section). The appropriate porphyrins $\mathrm{H}_{2} \mathrm{TPP}\left(4-\mathrm{SiRR}^{\prime}-\right.$ $\mathrm{Me})_{4}\left(3 \mathbf{a}, \mathrm{R}=\mathrm{R}^{\prime}=\mathrm{Me} ; 3 \mathbf{b}, \mathrm{R}=\mathrm{Me}, \mathrm{R}^{\prime}=\mathrm{CH}_{2} \mathrm{CH}=\mathrm{CH}_{2} ; \mathbf{3 c}, \mathrm{R}=\right.$ $\mathrm{R}^{\prime}=\mathrm{CH}_{2} \mathrm{CH}=\mathrm{CH}_{2}$; TPP = tetraphenyl porphyrin) were isolated as dark red solids with yields of between 25 and 30\% (see the Experimental section). The corresponding zinc(II)-porphyrins $\mathrm{Zn}-\mathrm{TPP}\left(4-\mathrm{SiRR}^{\prime} \mathrm{Me}\right)_{4}\left(\mathbf{4 a}, \mathrm{R}=\mathrm{Me}, \mathrm{R}^{\prime}=\mathrm{CH}_{2} \mathrm{CH}=\mathrm{CH}_{2} ; \mathbf{4 b}, \mathrm{R}=\right.$ $\mathrm{R}^{\prime}=\mathrm{CH}_{2} \mathrm{CH}=\mathrm{CH}_{2}$ ) were obtained in virtually quantitative yields upon treatment of $\mathbf{3 b}$ or $\mathbf{3} \mathbf{c}$ with zinc(II) acetate in a mixture of $\mathrm{CHCl}_{3}-\mathrm{MeOH}$ (ratio $5: 1, \mathrm{v} / \mathrm{v}$ ) (Scheme 1, see the Experimental section).
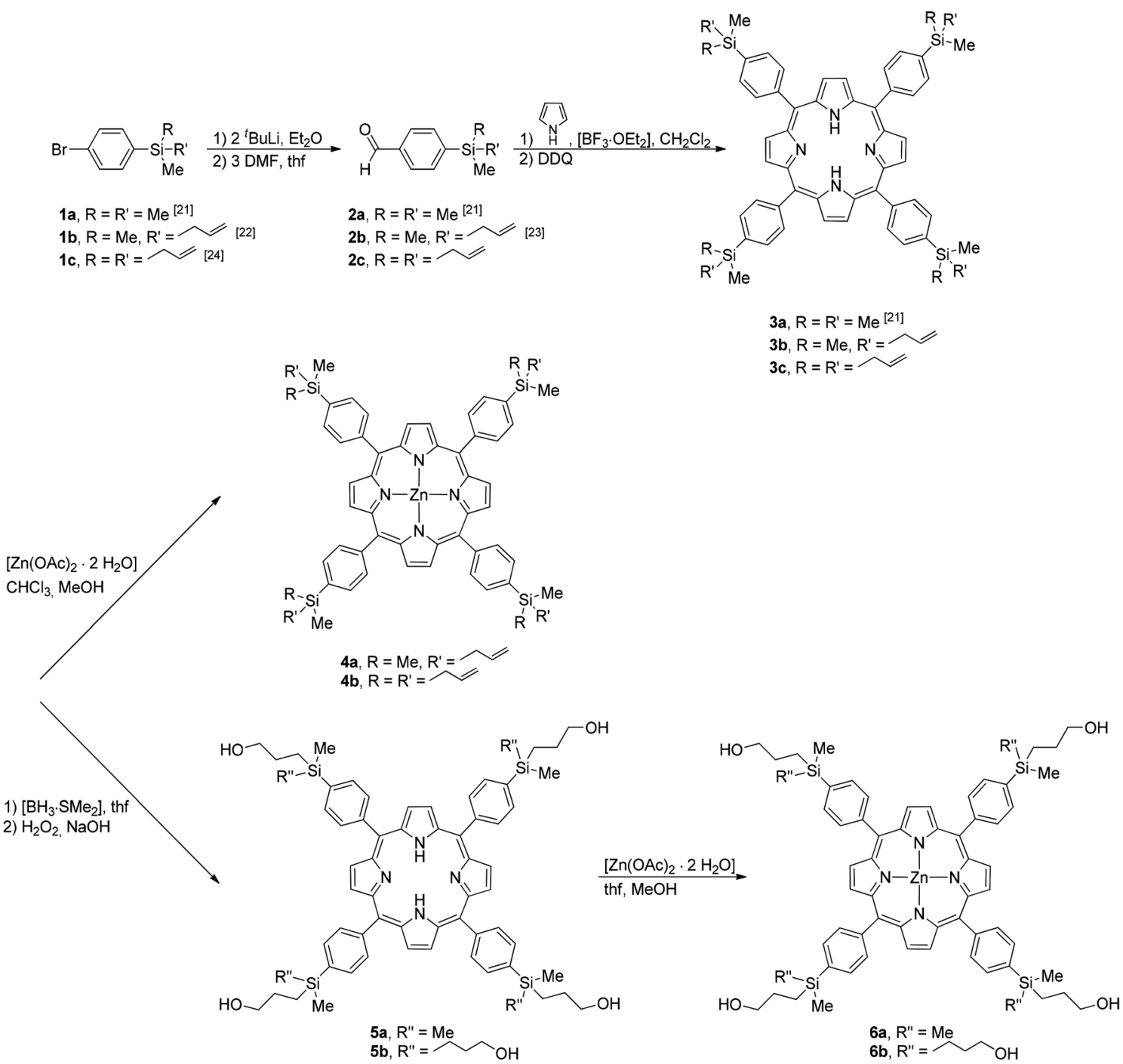

Scheme 1 Synthesis of 2-6..$^{21-24}$ 
Porphyrins $\mathbf{3} \mathbf{b}$ and $\mathbf{3 c}$, respectively, with their terminal $\mathrm{SiCH}_{2} \mathrm{CH}=\mathrm{CH}_{2}$ units could successfully be converted to the corresponding Si-propanolic-functionalized porphyrins 5a and 5b by a consecutive hydroboration-oxidation procedure (Scheme 1, see the Experimental section). Hydroboration of the appropriate end-grafted allyl groups with $\left[\mathrm{BH}_{3} \cdot \mathrm{dms}\right]$ (dms = dimethyl sulfoxide $)$ in thf gave the corresponding $\mathrm{BH}_{2}$-functionalized systems, which on addition of hydrogen peroxide were oxidized to the respective alcohols $\mathrm{H}_{2}$ TPP(4-SiRR"Me) ${ }_{4}\left(5 \mathbf{a}, \mathrm{R}=\mathrm{Me}, \mathrm{R}^{\prime \prime}=\mathrm{CH}_{2} \mathrm{CH}_{2} \mathrm{CH}_{2} \mathrm{OH} ; \mathbf{5 b}, \mathrm{R}=\mathrm{R}^{\prime \prime}=\right.$ $\mathrm{CH}_{2} \mathrm{CH}_{2} \mathrm{CH}_{2} \mathrm{OH}$ ) (Scheme 1). These porphyrins produce, when reacted with the transition metal salt $\left[\mathrm{Zn}(\mathrm{OAc})_{2} \cdot 2 \mathrm{H}_{2} \mathrm{O}\right]$, the expected zinc(II) species $\mathrm{Zn}(\mathrm{II})-\mathrm{TPP}\left(4-\mathrm{SiRR}^{\prime \prime} \mathrm{Me}\right)_{4}$ (6a, R = Me, $\mathrm{R}^{\prime \prime}=\mathrm{CH}_{2} \mathrm{CH}_{2} \mathrm{CH}_{2} \mathrm{OH} ; \mathbf{6 b}, \mathrm{R}=\mathrm{R}^{\prime \prime}=\mathrm{CH}_{2} \mathrm{CH}_{2} \mathrm{CH}_{2} \mathrm{OH}$ ) in virtually quantitative yield (Scheme 1, see the Experimental section). Zinc porphyrins $\mathbf{6 a}$ and $\mathbf{6 b}$ dissolve in most common organic solvents.

The synthesis procedure used in the preparation of 3-6 (Scheme 1) could successfully be transferred to the synthesis of the $1^{\text {st }}$ generation carbosilane-based porphyrins $9 \mathbf{a}-\mathbf{c}$ and $10 a-c$
(Scheme 2). The therefore necessary key aldehyde starting materials 1- $\mathrm{H}(\mathrm{O}) \mathrm{C}-\mathrm{C}_{6} \mathrm{H}_{4}-4-\mathrm{Si}\left(\mathrm{C}_{6} \mathrm{H}_{4}-1,4-\mathrm{SiRR}^{\prime} \mathrm{Me}\right)_{3}\left(\mathbf{8 a}, \mathrm{R}=\mathrm{R}^{\prime}=\right.$ Me; 8b, R = Me, $\mathrm{R}^{\prime}=\mathrm{CH}_{2} \mathrm{CH}=\mathrm{CH}_{2} ; \mathbf{8 c}, \mathrm{R}=\mathrm{R}^{\prime}=\mathrm{CH}_{2} \mathrm{CH}=\mathrm{CH}_{2}$ ) were obtained with a two-step synthesis procedure from 1-Br$\mathrm{C}_{6} \mathrm{H}_{4}-4-\mathrm{Si}\left(\mathrm{C}_{6} \mathrm{H}_{4}-1,4-\mathrm{SiRR}^{\prime} \mathrm{Me}\right)_{3}\left(7 \mathrm{a}, \mathrm{R}=\mathrm{R}^{\prime}=\mathrm{CH}_{3} ; 7 \mathbf{b}, \mathrm{R}=\mathrm{CH}_{3}\right.$, $\left.\mathrm{R}^{\prime}=\mathrm{CH}_{2} \mathrm{CH}=\mathrm{CH}_{2} ; 7 \mathrm{c}, \mathrm{R}=\mathrm{R}^{\prime}=\mathrm{CH}_{2} \mathrm{CH}=\mathrm{CH}_{2}\right)$.

After appropriate work-up, aldehydes 8a-c were obtained in excellent yield, and porphyrins 3, 5 and 9 in yields between 25 and $40 \%$, while the formation of the respective zinc(II)-porphyrins 4, 6 and 10 was quantitative (see the Experimental section). All carbosilane-functionalized (metallo)porphyrins are, as the aldehyde starting materials, dark red colored solids soluble in most common polar organic solvents. They are airand moisture-stable with decomposition or melting points between 200 and $350^{\circ} \mathrm{C}$ (see the Experimental section). Aldehydes $\mathbf{8}$ and porphyrins 3-6 and 9-10 were characterized by elemental analysis, IR, UV-Vis and NMR spectroscopy $\left({ }^{1} \mathrm{H}\right.$, ${ }^{13} \mathrm{C}\left\{{ }^{1} \mathrm{H}\right\},{ }^{29} \mathrm{Si}\left\{{ }^{1} \mathrm{H}\right\}$ ) (see the Experimental section). ESI-TOF mass spectrometric measurements were additionally carried out with selected metal-free and zinc(II) metallated samples

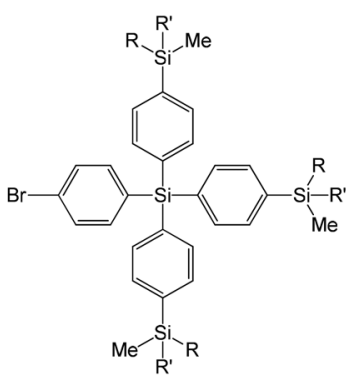

7a, $R=\mathrm{R}^{\prime}=\mathrm{Me}{ }^{[24]}$

$\left.7 b, R=M e, R^{\prime}=>{ }^{[18 a}\right]$

7c, $R=R^{\prime}=$

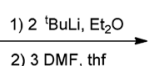

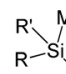<smiles>C[Si](C)(C)C1CCCC1</smiles><smiles>CCC(C)=S(C)(N)=O</smiles>

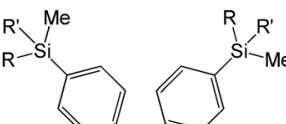

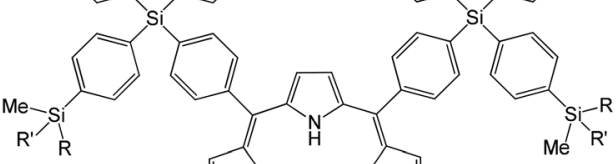

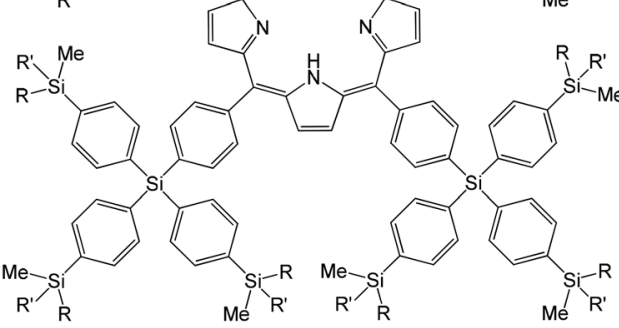

$9 a, R=R^{\prime}=M e$

$\left.9 b, R=M e, R^{\prime}={ }^{[18 a}\right]$

$9 c, R=R^{\prime}=$
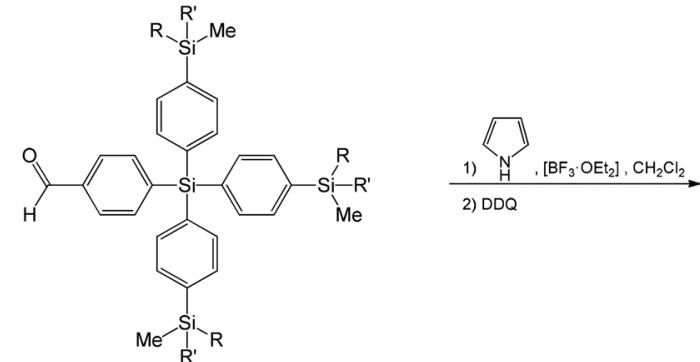

$8 \mathrm{a}, \mathrm{R}=\mathrm{R}^{\prime}=\mathrm{Me}$

$8 b, R=M e, R^{\prime}=$

$8 c, R=R^{\prime}=$
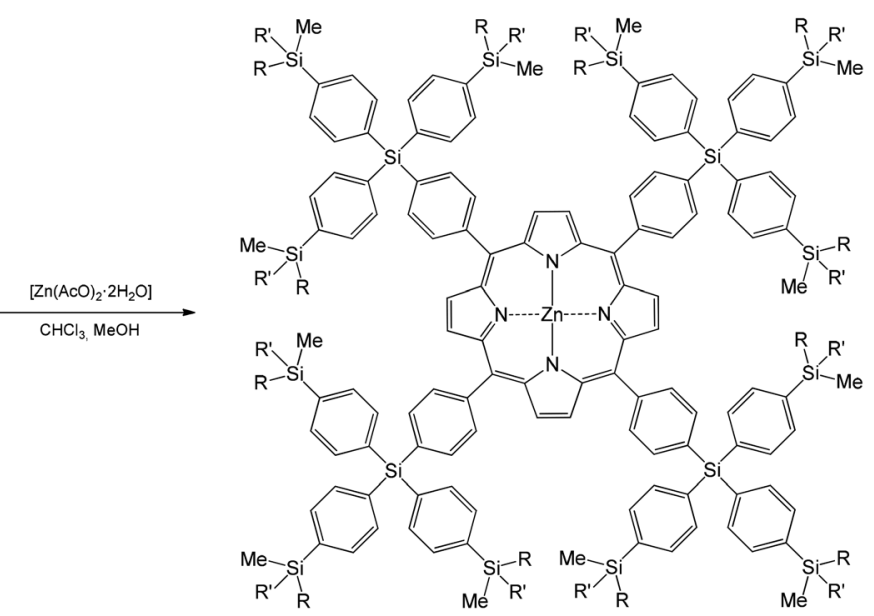

10a, $R=R^{\prime}=M e$

$10 \mathrm{~b}, \mathrm{R}=\mathrm{Me}, \mathrm{R}^{\prime}=$

10c, $R=R^{\prime}=$

Scheme 2 Synthesis of 8-10. ${ }^{18 a, 24}$ 
(2c, 3b,c, 4a,b, 5a,b, 6a,b and 8a,c). The identity of 3b,c, 4a, $6 \mathbf{a}$ and $\mathbf{9 b}$ in the solid state was confirmed by single X-ray diffraction studies (vide infra).

The IR spectra of the newly synthesized allyl carbosilanebased porphyrins (Schemes 1 and 2) show a characteristic $\nu_{\mathrm{C}=\mathrm{C}}$ vibration at $c a .1630 \mathrm{~cm}^{-1}$ together with one or two typical absorptions in the range of $800-840 \mathrm{~cm}^{-1}$ for the $\mathrm{Si}-\mathrm{C}$ stretching vibrations (see the Experimental section). The $\mathrm{CH}_{3}$ bending vibration of the $\operatorname{SiMe}_{n}$ entities $(n=1,2,3)$ is observed at $c a .1250 \mathrm{~cm}^{-1}$. These findings are in agreement with allylfunctionalized carbosilanes, i.e. $\mathrm{Si}\left(\mathrm{CH}_{2} \mathrm{CH}=\mathrm{CH}_{2}\right)_{4}$ (ref. 25). Further characteristic broad absorptions are observed at ca. 3315 and $3400 \mathrm{~cm}^{-1}$, which can be assigned to the $\mathrm{NH}$ as well as $\mathrm{OH}$ groups. The aldehyde functionalities present in $\mathbf{2}$ and $\mathbf{8}$ gave characteristic bands at 2732 and $2820 \mathrm{~cm}^{-1}$ for the $\mathrm{CH}$ and at $1705 \mathrm{~cm}^{-1}$ for the CO moieties. In addition, IR spectroscopy can be applied to monitor the progress of the hydroboration of 3 with $\left[\mathrm{BH}_{3} \cdot \mathrm{SMe}_{2}\right]$, since the $\nu_{\mathrm{C}=\mathrm{C}}$ vibration of the allylic units in the respective starting compounds (ca. $1630 \mathrm{~cm}^{-1}$ ) disappears in the course of the reaction. After $\mathrm{H}_{2} \mathrm{O}_{2}$ treatment new bands for the terminal hydroxyl functionalities in $\mathbf{5 a}$ and $\mathbf{5 b}$ are found at $c a .3400 \mathrm{~cm}^{-1}$, which is typical for primary alcohols. ${ }^{26}$ Solely broad absorptions are observed in the IR spectra; hydrogen-bridge formation and hence formation of molecular networks are the most obvious. $^{27}$

The ${ }^{1} \mathrm{H}$ and ${ }^{13} \mathrm{C}\left\{{ }^{1} \mathrm{H}\right\}$ NMR spectra of all compounds are characterized by well-resolved resonance signals for the organic groups present (see the Experimental section). Most typical for aldehydes $\mathbf{2 b , \mathbf { c }}$ and $\mathbf{8 a - c}$ is the resonance signal at $10.07 \mathrm{ppm}$. This functionality allows the monitoring of the progress of the appropriate porphyrin formation because this signal disappears during the course of the reaction. Further evidence for the successful formation of the porphyrins is the appearance of a singlet at $8.92 \mathrm{ppm}$, which can be assigned to the pyrrole hydrogen atoms. ${ }^{28}$ Also very distinctive is the resonance signal of the $\mathrm{NH}$ units at $-2.8 \mathrm{ppm}$, while zincation leads to the disappearance of this signal and hence this unit can also be used to monitor the formation of the appropriate zinc porphyrins. Further indicative groups are the SiMe, $\mathrm{Si}\left(\mathrm{CH}_{2}\right)_{3} \mathrm{Me}$, and $\mathrm{SiCH}_{2} \mathrm{CH}=\mathrm{CH}_{2}$ entities (see the Experimental section). Particularly the latter group is best suited to study the progress of the consecutive hydroboration-oxidation processes since new resonances for the $\mathrm{Si}\left(\mathrm{CH}_{2}\right)_{3} \mathrm{OH}$ building blocks are found (see the Experimental section). Similar to the IR spectra, the representative resonance signals for the $\mathrm{SiCH}_{2} \mathrm{CH}=\mathrm{CH}_{2}$ groups in $3 \mathbf{b}$ and $3 \mathbf{c}$ at ca. $2.0\left(\mathrm{SiCH}_{2}\right)$, $5.0\left(\mathrm{H}_{2} \mathrm{C}=\right)$ and $6.0 \mathrm{ppm}(\mathrm{CH}=)$ (in $\left.\mathrm{CDCl}_{3}\right)$ disappear on hydroboration and after oxidation with $\mathrm{H}_{2} \mathrm{O}_{2}$ new signals can be found at $0.9\left(\mathrm{SiCH}_{2} \mathrm{CH}_{2} \mathrm{CH}_{2} \mathrm{OH}\right), 1.7\left(\mathrm{SiCH}_{2} \mathrm{CH}_{2} \mathrm{CH}_{2} \mathrm{OH}\right)$, $3.5\left(\mathrm{SiCH}_{2} \mathrm{CH}_{2} \mathrm{CH}_{2} \mathrm{OH}\right)$ and $4.5 \mathrm{ppm}\left(\mathrm{SiCH}_{2} \mathrm{CH}_{2} \mathrm{CH}_{2} \mathrm{OH}\right)$ for alcohols $\mathbf{5 a}$ and $\mathbf{5 b}$ (in dmso- $d_{6}$ ), respectively. Similar observations were made in the ${ }^{13} \mathrm{C}\left\{{ }^{1} \mathrm{H}\right\}$ NMR spectroscopic studies (see the Experimental section).

Additionally, the ${ }^{29} \mathrm{Si}\left\{{ }^{1} \mathrm{H}\right\}$ spectra of the carbosilane-based porphyrins $\mathbf{3 b}, \mathbf{c}, \mathbf{4 a}, \mathbf{b}, \mathbf{9 b}, \mathbf{c}$ and $\mathbf{1 0 a}, \mathbf{b}$ and the aldehydes $\mathbf{2 b , \mathbf { c }}$ and $\mathbf{8 b}, \mathbf{c}$ were measured. For example, the ${ }^{29} \mathrm{Si}\left\{{ }^{1} \mathrm{H}\right\}$ NMR spectra of 9 and 10 (in $\mathrm{CDCl}_{3}$ ) show, as expected, two resonance signals at $c a$. $-14.5 \mathrm{ppm}$ and between -3.9 and $-5.7 \mathrm{ppm}$, which can be assigned to the core and terminal silicon atoms (see the Experimental section). ${ }^{24}$ The values for the inner silicon atoms are in good agreement with tetraphenyl silane $(-14.98 \mathrm{ppm}){ }^{29}$

ESI-TOF mass spectrometric studies were carried out for all aldehyde derivatives and the $0^{\text {th }}$ generation porphyrins. Compounds 2c, 3b,c and 5a show the protonated molecular ion peak $[\mathrm{M}+\mathrm{H}]^{+}$, while for $\mathbf{4 a}, \mathbf{b}[\mathrm{M}]^{+}$is characteristic. Compounds 5b, 6a,b and 8a,c could successfully be ionized by doping with $\mathrm{KSCN}$ and hence the ion $[\mathrm{M}+\mathrm{K}]^{+}$could be detected (see the Experimental section).

UV-Vis absorption spectra were additionally recorded for porphyrins $\mathbf{3} \mathbf{b}, \mathbf{c}, \mathbf{4} \mathbf{a}, \mathbf{b}, \mathbf{5 a}, \mathbf{b}, \mathbf{6 a}, \mathbf{b}, \mathbf{9 a}-\mathbf{c}$ and $\mathbf{1 0 a - c}$, in order to analyze the effect of the dendritic branches on the optical properties of the porphyrin ring. The spectra were measured in $\mathrm{CH}_{2} \mathrm{Cl}_{2}$ and thf as solvents (Table 1 ). The porphyrin core of $\mathbf{3} \mathbf{b}$ shows one Soret band at $420 \mathrm{~nm}$ in $\mathrm{CH}_{2} \mathrm{Cl}_{2}$ and four $Q$ bands at 517, 552, 592 and $648 \mathrm{~nm}$ (Fig. 1a). ${ }^{30}$ Metallation of $3 \mathbf{b}$ with zinc(II) did not influence the position of the soret band (4a, $421 \mathrm{~nm}$, in $\mathrm{CH}_{2} \mathrm{Cl}_{2}$ ) (Fig. 1b) but has a significant impact on the shape of the $Q$ band pattern. Two characteristic bands at 549 and $588 \mathrm{~nm}$ are observed in $\mathrm{CH}_{2} \mathrm{Cl}_{2}$, which is typical for metallo-porphyrins. ${ }^{31}$ Fig. 1 also shows the difference between the UV-Vis spectra of the corresponding $0^{\text {th }}$ and $1^{\text {st }}$ generation dendritic porphyrins. Conspicuous is that the transitions typical for the $1^{\text {st }}$ generation dendritic porphyrins, for example, $\mathbf{9 b}$, are nearly meeting the shape of the bands of the appropriate $0^{\text {th }}$ generation systems, as, for example $\mathbf{3 b}$, with just little enhancement of the band intensities and a very small red shift in the Soret band (Fig. 1a). Similar observations were made for zinc porphyrins $\mathbf{4 a}$ and $\mathbf{1 0 b}$ (Fig. 1b). The increasing shielding effect of growing dendrons around the porphyrin core as, for example, described by Aida and coworkers for an aryl ether scaffold ${ }^{30 b, c}$ does not appear in the case of our systems. The reason therefore is apparent when looking at the molecular structure of the $1^{\text {st }}$ generation $9 \mathbf{b}$ (Fig. 10/11). Compared to aryl ether dendrons, the here reported aryl silyl dendrons (e.g. 9b) are more rigid. A backfolding, as observed for the aryl ether dendrons, is impossible and that implies that the porphyrin core plane is even in the $1^{\text {st }}$ generation type compounds easily accessible from above and below by solvents. A dendritic effect is therefore not observed by comparing the UV-Vis data of the $0^{\text {th }}$ and $1^{\text {st }}$ generation molecules. The data correlate well with reported literature spectra for silyl-functionalized porphyrins. ${ }^{32}$

\section{X-ray investigations}

Single crystals of $\mathbf{3 b}$ (as $\mathbf{3 b} \cdot \mathbf{1} / \mathbf{4} \mathbf{C H}_{\mathbf{2}} \mathbf{C l}_{\mathbf{2}}$ ), 3c, $\mathbf{4 a}$ and $\mathbf{9 b}$ (as 9b·3.5EtOH) were grown by slow diffusion of $\mathrm{CH}_{2} \mathrm{Cl}_{2}$ into EtOH solutions containing the respective compounds, while single crystals of $6 \mathbf{a}$ (as $\mathbf{6 a} \cdot \mathbf{2 t h f}$ ) were obtained by layering a thf solution containing $\mathbf{6 a}$ with ${ }^{n}$ pentane at ambient temperature. The molecular structures of $\mathbf{3 b}, \mathbf{c}, \mathbf{4 a}$ and $\mathbf{6 a}$ are displayed in Fig. 2, 
Table 1 UV-Vis absorptions of porphyrins 3-6, 9 and 10

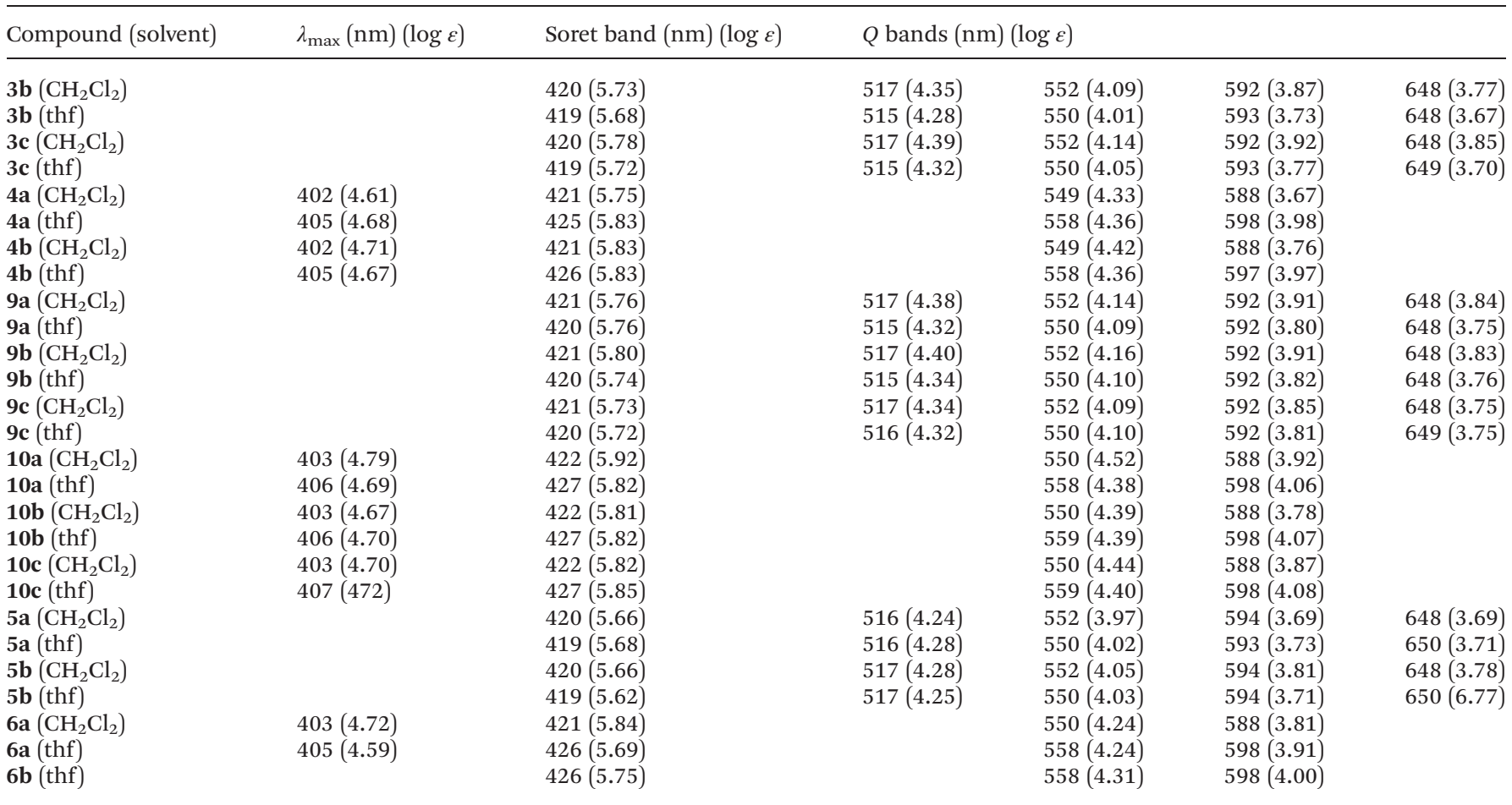
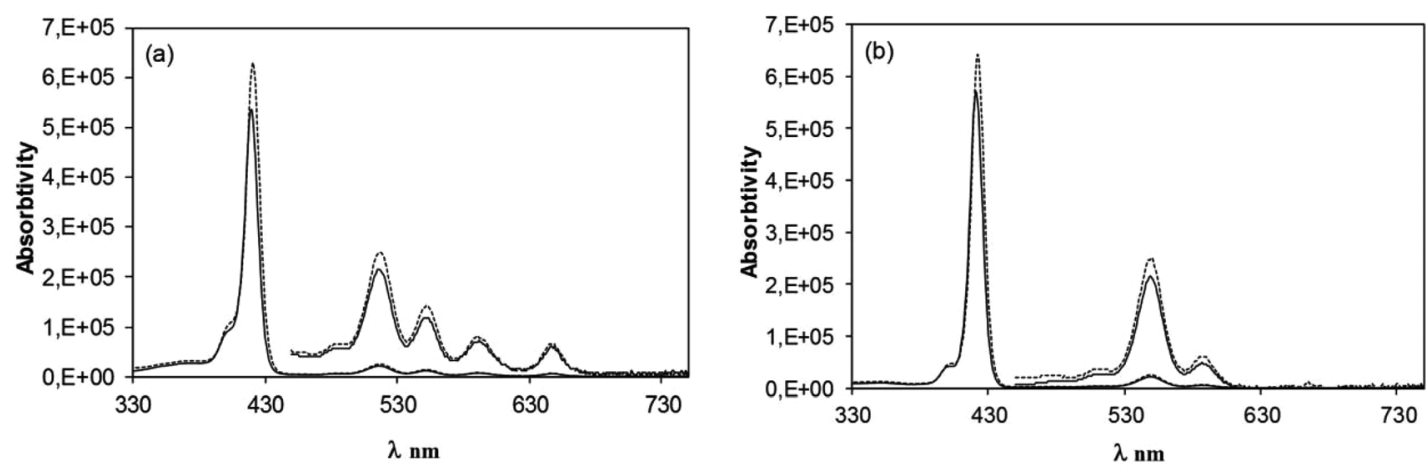

Fig. 1 Absorption spectra of $3 b(-)$ vs. $9 b(\ldots)$ (a) and $4 a(-)$ vs. $10 b(\ldots)$ (b) in $\mathrm{CH}_{2} \mathrm{Cl}_{2}$.

6, 3 and 8. In the case of $9 \mathbf{b}$ the asymmetric unit comprises two crystallographically independent centrosymmetric halves of $\mathbf{9 b}$, denoted as $\mathbf{9 b A}$ and $\mathbf{9 b B}$. Their molecular structures are depicted in Fig. 10 and 11. Crystal and intensity collection data of $3 \mathbf{b} \cdot \mathbf{1} / \mathbf{4} \mathrm{CH}_{2} \mathrm{Cl}_{2}, 3 \mathbf{c}, \mathbf{4 a}, \mathbf{6 a} \cdot \mathbf{2 t h f}$ and $\mathbf{9 b} \cdot \mathbf{3 . 5 E t O H}$ are summarized in Table $\mathrm{S} 1, \dagger$ while selected bond lengths and angles are given in Tables 2 and 3, respectively.

As already mentioned for $\mathbf{9 b}$, even $\mathbf{3 c}$ possesses in the solid state crystallographically imposed inversion symmetry, whereby the inversion centres are located in the middle of the atoms N2/N2A (3c, Fig. 6), N1/N1A (9bA, Fig. 10) and N4/N4A (9bB, Fig. 11). For all other crystallographically characterized porphyrins no crystallographically implied symmetry is observed, thus $\mathbf{3 b} \cdot \mathbf{1} / \mathbf{4} \mathbf{C H}_{2} \mathbf{C l}_{2}, \mathbf{4 a}$, and $\mathbf{6 a} \cdot \mathbf{2 t h f}$ are $C_{1}$ symmetric in the solid state.
It should be emphasised that meso-tetraphenylporphyrins carrying at the para position any kind of Si-containing groups have been sparingly characterised by single crystal X-ray diffraction studies so far. The solid state structures of 5,10,15,20tetrakis(4-pentamethyldisilanyl)phenyl)porphyrin ${ }^{32 a}$ and of 5,10,15,20-tetrakis[4-(diethoxymethylsilyl)phenyl]porphyrin ${ }^{32 b}$ are already described in the literature.

However, experimentally observed bond lengths and angles for the end-grafted carbosilane branches of all functionalized meso-tetraphenylporphyrins described here are in agreement with parameters typically found for phenylene-based carbosilanes. ${ }^{24,33}$

The molecular structures of $\mathrm{H}_{2} \mathrm{TPP}\left(4-\mathrm{SiMe}_{2}\left(\mathrm{CH}_{2} \mathrm{CH}=\mathrm{CH}_{2}\right)\right)_{4}$ (3b) and its related zinc(II) species $\mathrm{Zn}(\mathrm{II})-\mathrm{TPP}(4-$ $\left.\mathrm{SiMe}_{2}\left(\mathrm{CH}_{2} \mathrm{CH}=\mathrm{CH}_{2}\right)\right)_{4}(\mathbf{4 a})$ in the solid state are depicted in 


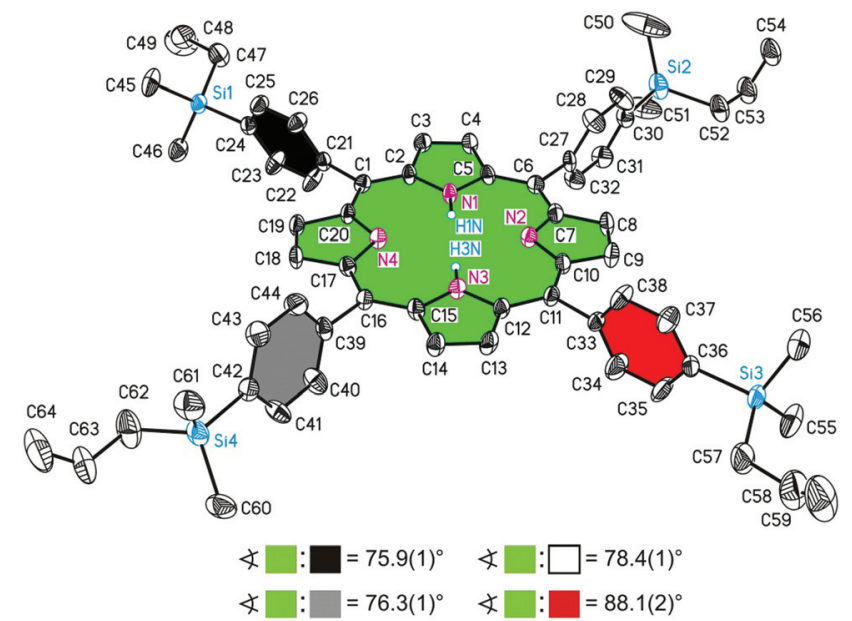

Fig. 2 ORTEP diagram ( $50 \%$ ellipsoid probability) of the molecular structure of $3 \mathrm{~b}$. All C-bonded hydrogen atoms are omitted for clarity. Of disordered atoms only one atomic position is displayed. The sign $\varangle$ refers to calculated interplanar angles between terminal $\mathrm{C}_{6} \mathrm{H}_{4}$ groups and the central $\mathrm{C}_{20} \mathrm{~N}_{4} \mathrm{H}_{2}$ core.

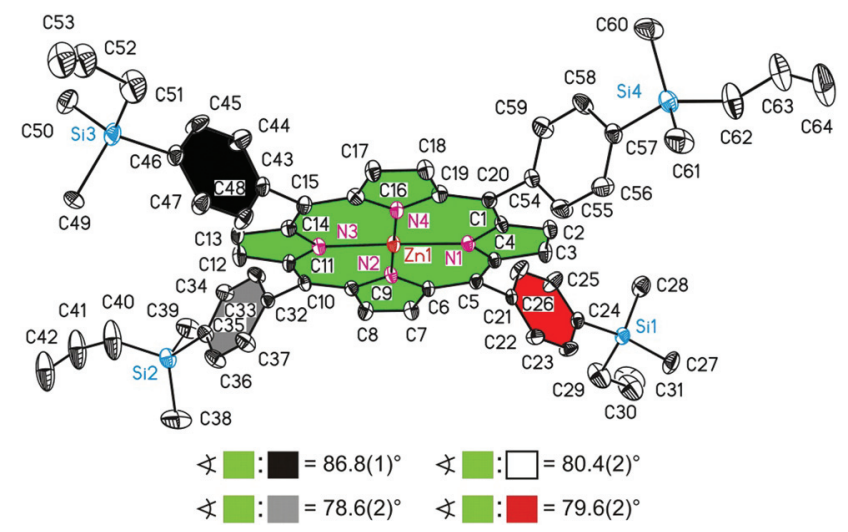

Fig. 3 ORTEP diagram (50\% ellipsoid probability) of the molecular structure of $4 \mathrm{a}$. All hydrogen atoms are omitted for clarity. Of disordered atoms only one atomic position is displayed. The sign $\varangle$ refers to calculated interplanar angles between terminal $\mathrm{C}_{6} \mathrm{H}_{4}$ groups and the central $\mathrm{C}_{20} \mathrm{~N}_{4} \mathrm{Zn}$ core.

Fig. 2 and 3. Both porphyrins crystallize in the tetragonal space group $P 4_{3}$ with similar dimensions of their respective unit cells (Table $\mathrm{S} 1 \dagger$ ). For $\mathbf{3 b}$ a partially occupied packing solvent molecule of $\mathrm{CH}_{2} \mathrm{Cl}_{2}$ is observed in the crystal structure, which should be found for $\mathbf{4 a}$ as well. However, no electron density peaks of $\mathbf{4 a}$ could be used for the refinement of an analogous packing solvent molecule. Despite this, $\mathbf{3 b}$ and $\mathbf{4 a}$ can be regarded as structurally isomorphic to each other.

The asymmetric unit of both $\mathbf{3 b}$ and $\mathbf{4 a}$ possesses one crystallographically independent porphyrin molecule. Related bond lengths and angles of the $\mathrm{C}_{20} \mathrm{~N}_{4}$ cores of $\mathbf{3 b}$ and $\mathbf{4 a}$ can be considered as identical to each other within standard deviations (Tables 2 and 3). Not surprisingly, the $\mathrm{N} \cdots \mathrm{N}$ distances of opposite nitrogen atoms of $\mathbf{3} \mathbf{b}$ are significantly longer, when compared with $4 \mathrm{a}(3 \mathrm{~B}, \mathrm{~N} 1 \cdots \mathrm{N} 3 / \mathrm{N} 2 \cdots \mathrm{N} 4=4.160(5) / 4.113(5) \AA$

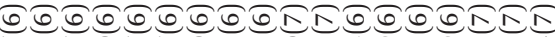

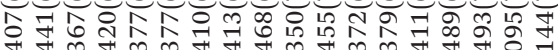

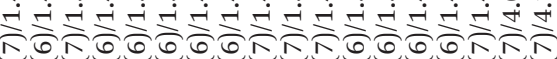

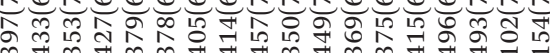

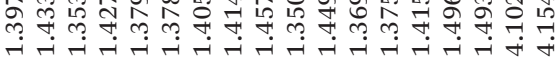

ఫิ बి

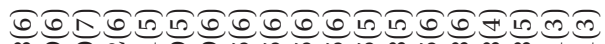

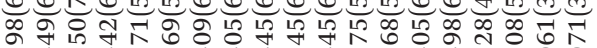

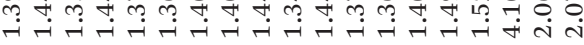

అే ปี

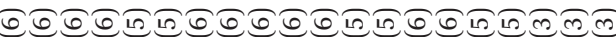

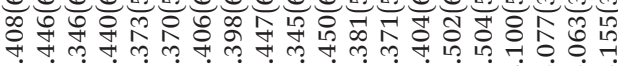

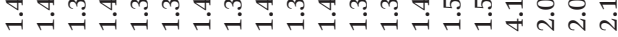

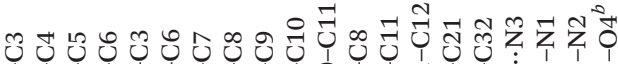
ป̂

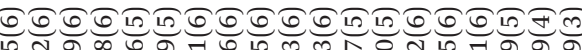

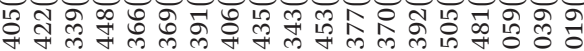

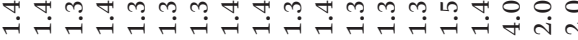

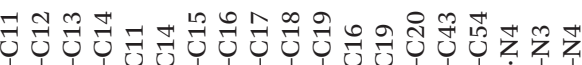

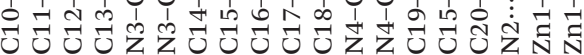

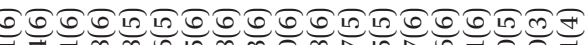

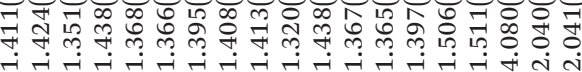

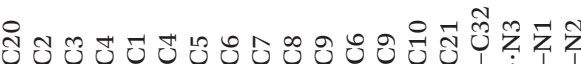

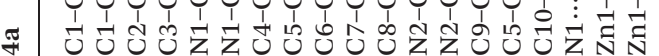

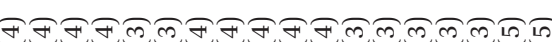

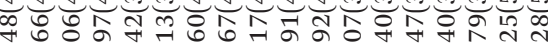

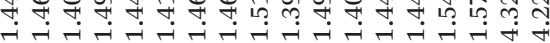

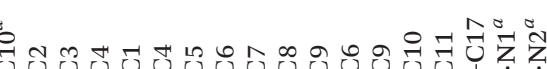

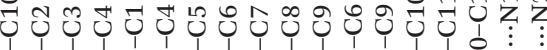
ઇ

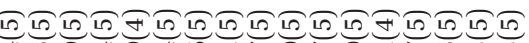
象

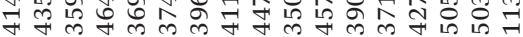

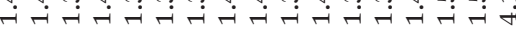

ปૈ

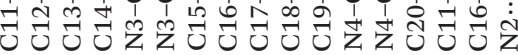

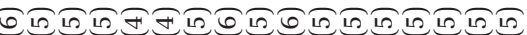

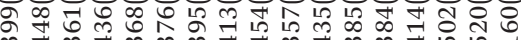

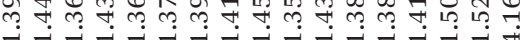




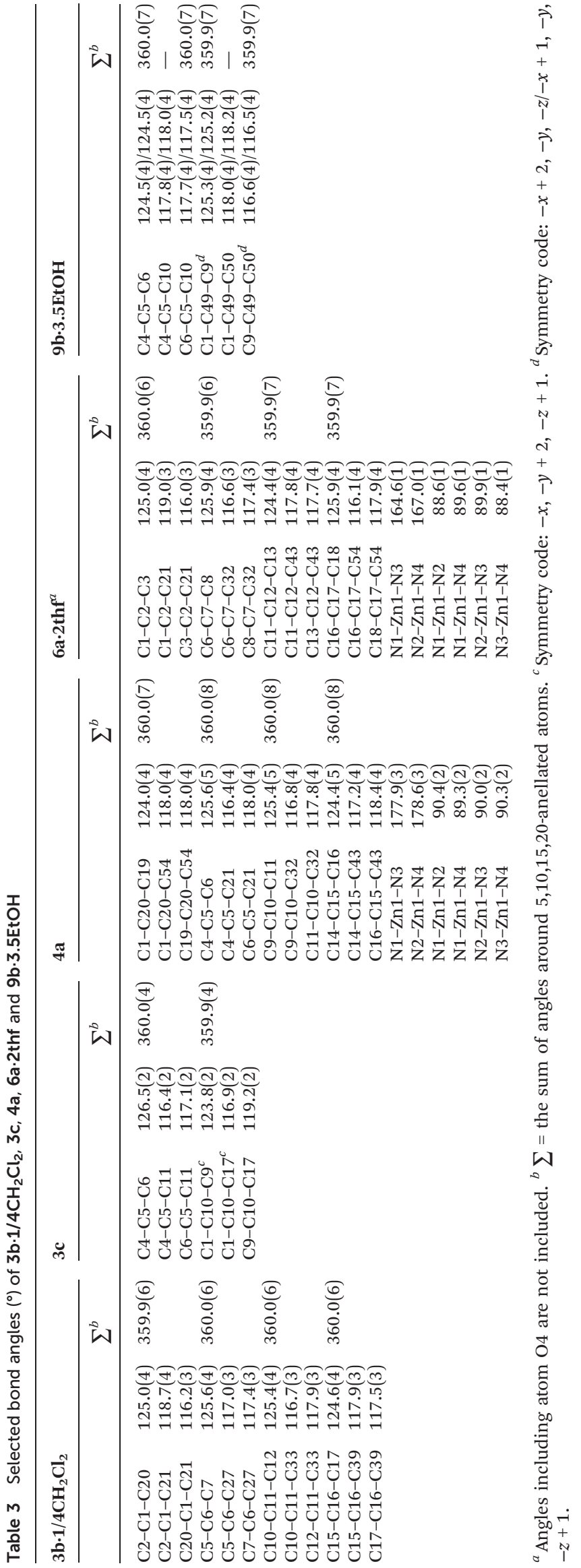

vs. $4 \mathrm{a}, \mathrm{N} 1 \cdots \mathrm{N} 3 / \mathrm{N} 2 \cdots \mathrm{N} 4=4.080(5) / 4.059(5) \AA)$, which nicely reflects the modification of the central $\mathrm{C}_{20} \mathrm{~N}_{4}$ core upon complexation. The Zn(II) ion of $\mathbf{4 a}$ can be furthermore considered as being involved in an ideal quadratic planar $\mathrm{ZnN}_{4}$ coordination environment. $\mathrm{Zn}-\mathrm{N}$ bond lengths of $4 \mathrm{a}$ cover a very narrow range $(\mathrm{Zn} 1-\mathrm{N} 4=2.019(3)$ to $\mathrm{Zn} 1-\mathrm{N} 2=2.041(4) \AA)$ and $\mathrm{N}-\mathrm{Zn}-\mathrm{N}$ bond angles are very close to the ideal values of trans-/ cis-ligated $\mathrm{N}$ donor atoms (trans: N1-Zn1-N3/N2-Zn1-N4 = 177.9(3)/178.6(3) ; cis: N1-Zn1-N4 = 89.3(2) to N1-Zn1-N2 = $\left.90.4(2)^{\circ}\right)$. Furthermore, the $\mathrm{Zn} 1$ atom is located practically in plane with respect to its $\mathrm{N}_{4}$ environment as it deviates by just $0.007(4) \AA$ of the calculated mean plane of the atoms N1 to N4 (root-mean-square deviation from planarity $(\mathrm{rmsd})=0.030 \AA$, highest deviation from planarity (hdp) observed for $\mathrm{N} 4$ with 0.031(2) ̊̊).

Porphyrins $\mathbf{3 b}$ and $\mathbf{4 a}$ are structurally isomorphic to each other (vide supra) and consequently their crystal structures are identical. For both porphyrins a 3D network structure is observed in the solid state of which a selected part has been illustrated in Fig. 4 (3b) and Fig. 5 (4a). Thereby it is observed that all four crystallographically different $\mathrm{C}_{6} \mathrm{H}_{4}$ rings are involved in T-shaped $\pi-\pi$ contacts ${ }^{34}$ with the respective $\mathrm{C}_{20} \mathrm{~N}_{4}$ cores (Fig. 4 and 5). Geometrical features of these $\pi-\pi$ contacts of $\mathbf{3 b}$ and $\mathbf{4 a}$ (Fig. 4 and 5) are in good agreement with each other, when comparing both molecules.

The molecular structure of $\mathrm{H}_{2} \mathrm{TPP}\left(4-\mathrm{SiMe}\left(\mathrm{CH}_{2} \mathrm{CH}=\mathrm{CH}_{2}\right)_{2}\right)$ (3c) in the solid state is depicted in Fig. 6. The replacement of one methyl group of the carbosilane $\mathrm{SiMe}_{2}\left(\mathrm{CH}_{2} \mathrm{CH}=\mathrm{CH}_{2}\right)$ moiety in $\mathbf{3} \mathbf{b}$ by an allyl unit, as characteristic for $\mathbf{3} \mathbf{c}$, induces considerable changes. In contrast to $\mathbf{3} \mathbf{b}$, porphyrin $\mathbf{3} \mathbf{c}$ crystallizes in the triclinic space group $P \overline{1}$ with crystallographically imposed inversion symmetry. Thus, the asymmetric unit of $\mathbf{3 c}$ comprises just half of the molecule, while the $2^{\text {nd }}$ half is generated by an inversion center which is located at the crossing point of the atoms N1/N1A and N2/N2A (Fig. 3). Furthermore, it is astonishing to notice that related bond lengths of the $\mathrm{C}_{20} \mathrm{~N}_{4}$ core of $3 \mathbf{c}$, when compared with those of $3 \mathbf{b}$ and $4 \mathbf{a}$ and those of $\mathbf{6 a}$ and $\mathbf{9 b}$ as well, are significantly elongated (Table 2). As a wrongly determined space group may cause such deviations the structural refinement of $3 \mathbf{c}$ was checked with the utmost precision; however, there are no indications that the unit cell dimensions and space group of $3 \mathbf{c}$ are not accurate (Table $\mathrm{S} 1 \dagger$ ). For example, the $\mathrm{N} \cdots \mathrm{N}$ distances of opposite $\mathrm{N}$ atoms of $3 \mathrm{c}(\mathrm{N} 1 \cdots \mathrm{N} 1 \mathrm{~A} / \mathrm{N} 2 \cdots \mathrm{N} 2 \mathrm{~A}=4.325(5) / 4.228(5) \AA)$ are by far the longest ones of the here described porphyrins (Table 2). A possible explanation of this unexpected observation for $3 \mathbf{c}$ might be drawn from the crystal structure of $3 \mathbf{c}$, which is illustrated in Fig. 7. In contrast to the observation of 3D network structures for $\mathbf{3 b}$ and $\mathbf{4 a}$ (Fig. 4 and 6) which are induced by T-shaped $\pi-\pi$ interactions, for $3 \mathbf{c}$ the formation of 2D layers has been noted. The 2D layers are formed along the crystallographic $a$ - and $b$-axes, but not along the crystallographic $c$-axes as depicted in Fig. S1 and S2. $\dagger$ Moreover, only the $\mathrm{C}_{6} \mathrm{H}_{4}$ aromatic group comprising the atoms $\mathrm{C} 11$ to $\mathrm{C} 16$ and symmetry generated analogues is involved in T-shaped $\pi-\pi$ interactions with the $\mathrm{C}_{20} \mathrm{~N}_{4}$ core of adjacent molecules. 


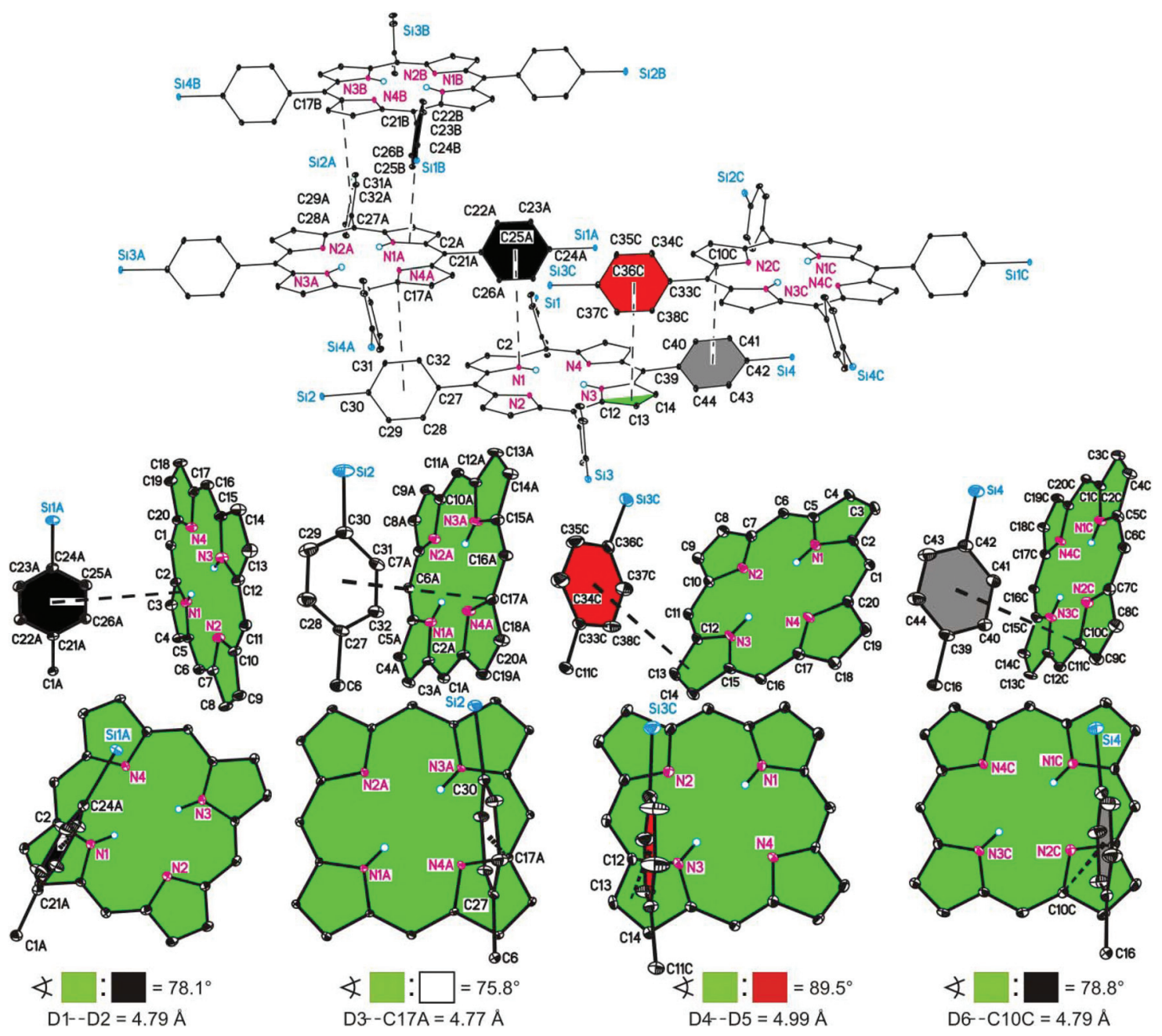

Fig. 4 Above: Graphical illustration of a selected part of the 3D network formed by $3 b$ due to intermolecular $\pi-\pi$ interactions. Labels A-C refer to a $1^{\text {st }}-3^{\text {rd }}$ symmetry generated molecule of $3 \mathrm{~b}$. All hydrogen atoms and terminal substituents at the silicon atoms are omitted for clarity. Below: graphical illustration of the four different types of intermolecular $\pi-\pi$ interactions between the aromatic $\mathrm{C}_{6} \mathrm{H}_{4}$ groups with respective parts of the porphyrin core. The sign $\varangle$ refers to calculated interplanar angles between differently colored functionalities. Dotted lines indicate the shortest observed distances between the geometrical centroids of the $\mathrm{C}_{6} \mathrm{H}_{4}$ groups and the respective centroids/atoms of the porphyrin core with $\mathrm{D} 1=$ centroid of C21-C26, D3 = centroid of C27-C32, D4 = centroid of C33-C38, D6 = centroid of C39-C44, D2 = centroid of N1 and C2, D5 = centroid of C12-C14 and symmetry generated related atoms/fragments.

Thereby, comparatively large centroid-to-centroid distances are observed (Fig. 7). To deduce that the different crystal structure of $\mathbf{3 c}$ is responsible for the observation of significantly different bond lengths of $\mathbf{3} \mathbf{c}$, when compared to those of $\mathbf{3 b}$ and $\mathbf{4 a}$, is certainly a more qualitative description. Hence, further work, e.g. quantum chemical calculations, is required to figure out the origin of this remarkable phenomenon.

The molecular structure of $\mathrm{Zn}(\mathrm{II})-\mathrm{TPP}\left(4-\mathrm{SiMe}_{2}\left(\left(\mathrm{CH}_{2}\right)_{3} \mathrm{OH}\right)\right)_{4}$ (6a) is depicted in Fig. 8. Porphyrin 6a crystallizes in the triclinic system $P \overline{1}$ with one molecule of $\mathbf{6 a}$ in the asymmetric unit cell. As indicated before, bond lengths and angles of the central $\mathrm{C}_{20} \mathrm{~N}_{4}$ core of $\mathbf{6 a}$ compare well with those of $\mathbf{3 b}, \mathbf{4} \mathbf{a}$ and 9b (Tables 2 and 3). Due to formation of an intermolecular $\mathrm{O}(\mathrm{H})-\mathrm{Zn}$ bond $(\mathrm{Zn} 1-\mathrm{O} 1=2.155(3) \AA)$, the $\mathrm{Zn}(\mathrm{II})$ ion of $\mathbf{6 a}$ is involved in an approximate square-based pyramidal $\mathrm{ZnN}_{4} \mathrm{O}$ coordination environment. Not surprisingly, as a consequence of the intermolecular $\mathrm{O}(\mathrm{H})-\mathrm{Zn}$ bond formation the $\mathrm{Zn} 1$ atom of $\mathbf{6 a}$ is significantly moved out of the basal plane into the direction of the coordinated $\mathrm{O}$ donor atom. Thus, the $\mathrm{Zn} 1$ atom is located $0.255(2) \AA$ above the calculated mean plane of the atoms N1 to N4 (rmsd $=0.022 \AA$, hdp observed for N3 with $0.022(2) \AA)$.

The exchange of the terminal allyl groups of $\mathbf{4 a}$ by 3-propyloxy functionalities, as present in $\mathbf{6 a}$, resulted in a completely different packing mode. There are no $\pi-\pi$ interactions of any kind observed for $\mathbf{6 a}$ in the solid state. Instead, the crystal structure is exclusively governed by reciprocal formation of intermolecular $\mathrm{O}(\mathrm{H})-\mathrm{Zn}$ contacts along the crystallographic $a$-axes together with formation of intermolecular $\mathrm{O}(\mathrm{H}) \cdots \mathrm{O}$ hydrogen bonds along the crystallographic $b$-axes. Fig. S3 and Table $\mathrm{S} 2 \dagger$ show bond lengths and angles for the characteristic intermolecular hydrogen bonds. A part of the thus formed 2D 


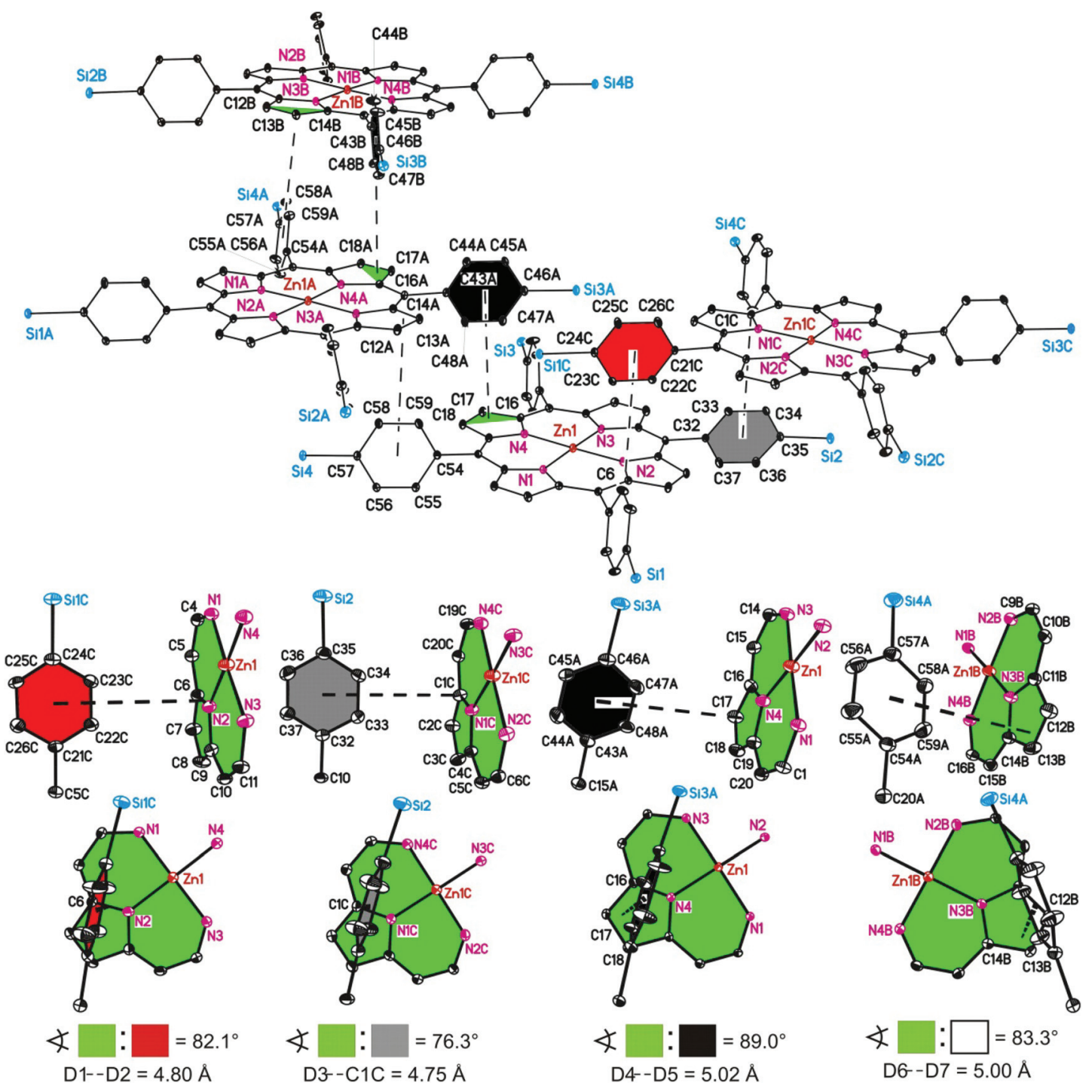

Fig. 5 Above: graphical illustration of a selected part of the 3D network formed by 4 a due to intermolecular $\pi-\pi$ interactions. Labels A-C refer to a $1^{\text {st }}$ to the $3^{\text {rd }}$ symmetry generated molecule of 4 a. All hydrogen atoms and terminal substituents at the silicon atoms are omitted for clarity. Below: graphical illustration of the four different types of intermolecular $\pi-\pi$ interactions between the aromatic $\mathrm{C}_{6} \mathrm{H}_{4}$ groups with the respective parts of the porphyrin core. The sign $\varangle$ refers to the calculated interplanar angles between differently colored functionalities. Dotted lines indicate the shortest observed distances between the geometrical centroids of the $\mathrm{C}_{6} \mathrm{H}_{4}$ groups and the respective centroids/atoms of the porphyrin core with D1 = centroid of C21-C26, D3 = centroid of C32-C37, D4 = centroid of C43-C48, D6 = centroid of C54-C59, D2 = centroid of N2 and C6, D5 = centroid of $\mathrm{C} 16-\mathrm{C} 18, \mathrm{D} 7$ = centroid of $\mathrm{C} 12-\mathrm{C} 14$ and symmetry generated related atoms/fragments.

layers is furthermore graphically illustrated in Fig. 9. It is surprising to note that the formation of $1 \mathrm{D}$ chains, as a part of the 2D network structure, due to mutual intermolecular $\mathrm{O}(\mathrm{H})-$ Zn contacts as observed for $\mathbf{6 a}$, has not been observed so far for any kind of O-functionalised metalloporphyrins possessing 3d transition metal ions. Related metalloporphyrins functionalised by any kind of O-donor atoms, with the oxygen atoms belonging to alcohol, ether, carbonic acid and/or carbonyl functionalities, form either dimers, ${ }^{35}$ trimers $^{36}$ or polymeric $2 \mathrm{D}^{37}$ and $3 \mathrm{D}^{38}$ networks, respectively.

Porphyrin $\mathrm{H}_{2} \mathrm{TPP}\left(4-\mathrm{Si}\left(\mathrm{C}_{6} \mathrm{H}_{4}-4-\mathrm{Si}\left(\mathrm{CH}_{2} \mathrm{CH}=\mathrm{CH}_{2}\right) \mathrm{Me}_{2}\right)_{3}\right)_{4}(\mathbf{9 b})$ crystallises in the triclinic space group $P \overline{1}$. The asymmetric unit contains half of two crystallographically independent molecules of $\mathbf{9 b}$, denoted as $\mathbf{9 b A}$ and $\mathbf{9 b B}$. Both $\mathbf{9 b A}$ and $\mathbf{9 b B}$ possess in the solid state crystallographically imposed inversion symmetry, whereby the molecular structures of both individual molecules are depicted in Fig. 10 and 11. The bond distances and angles of the $\mathrm{C}_{20} \mathrm{~N}_{4}$ cores of $\mathbf{9 b A}$ and $\mathbf{9 b B}$ do not only compare well with each other, they can be even considered as closely related to analogous data reported here for $\mathbf{3 b}, \mathbf{4 a}$ and $\mathbf{6 a}$ but not $\mathbf{3 c}$ (see above and Tables 2 and 3).

Due to the presence of sixteen crystallographically independent $\mathrm{C}_{6} \mathrm{H}_{4}$ aromatic rings of both $\mathbf{9 b A}$ and $\mathbf{9 b B}$, determination of the crystal structure of $\mathbf{9 b}$ with respect to possible $\pi-\pi$ interactions is rather complicated. ${ }^{39}$ However, it was found that a $3 \mathrm{D}$ network is formed by $\mathbf{9 b}$ in the solid state due to T-shaped 


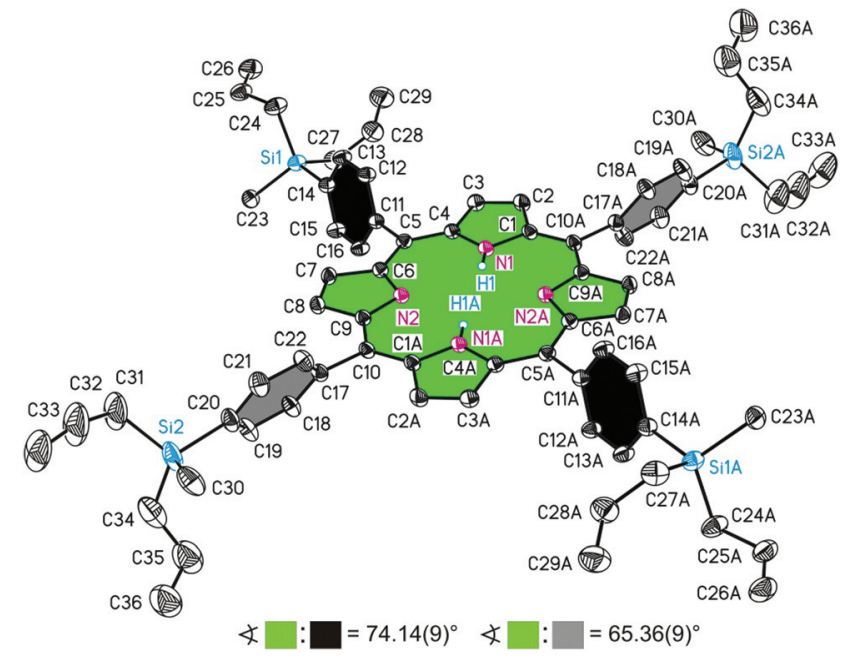

Fig. 6 ORTEP diagram (25\% ellipsoid probability) of the molecular structure of 3c. All C-bonded hydrogen atoms are omitted for clarity. Of disordered atoms only one atomic position is displayed. The sign $\varangle$ refers to the calculated interplanar angles between terminal $\mathrm{C}_{6} \mathrm{H}_{4}$ groups and the central $\mathrm{C}_{20} \mathrm{~N}_{4} \mathrm{H}_{2}$ core. Symmetry code for $\mathrm{A}:-x,-y+2,-z+1$. $\pi-\pi$ interactions. This 3D network can be understood as being formed of $2 \mathrm{D}$ layers of molecules of $\mathbf{9 b A}$ and $\mathbf{9 b B}$ of which a part is illustrated in Fig. 12. Further descriptions of the individual interactions are given in Fig. 14 and S4-S6. $\dagger$ The 2D layers interact then with each other by means of T-shaped $\pi-\pi$ interactions exclusively between molecules of either $\mathbf{9 b A}$ or 9bB (Fig. 13). The respective $\pi-\pi$ interactions being responsible for the formation of the $2 \mathrm{D}$ layers and of the $3 \mathrm{D}$ network are then separately illustrated in Fig. 14. The inter-layer distance between 2D layers corresponds to $25.1408 \AA$ (=b), (Fig. 13).

Different types of non-planar distortions commonly observed for porphyrins have been already explicitly discussed. ${ }^{41}$ In the case of here structurally described porphyrins it can be determined that the central $\mathrm{C}_{20} \mathrm{~N}_{4}$ porphyrin cores can be regarded as planar which can be concluded from, for example, the sum of angles around the 5,10,15,20-anellated atoms of the $\mathrm{C}_{20} \mathrm{~N}_{4}$ cores (Table 3) and further data are given in Table S3 and Fig. S7, $\uparrow$ including accompanying remarks.

In summary, the observation of the formation of $3 \mathrm{D}(\mathbf{3 b}, \mathbf{4 a}$ and $9 \mathbf{b}$ ) or $2 \mathrm{D}$ networks (3c) resulting from intermolecular

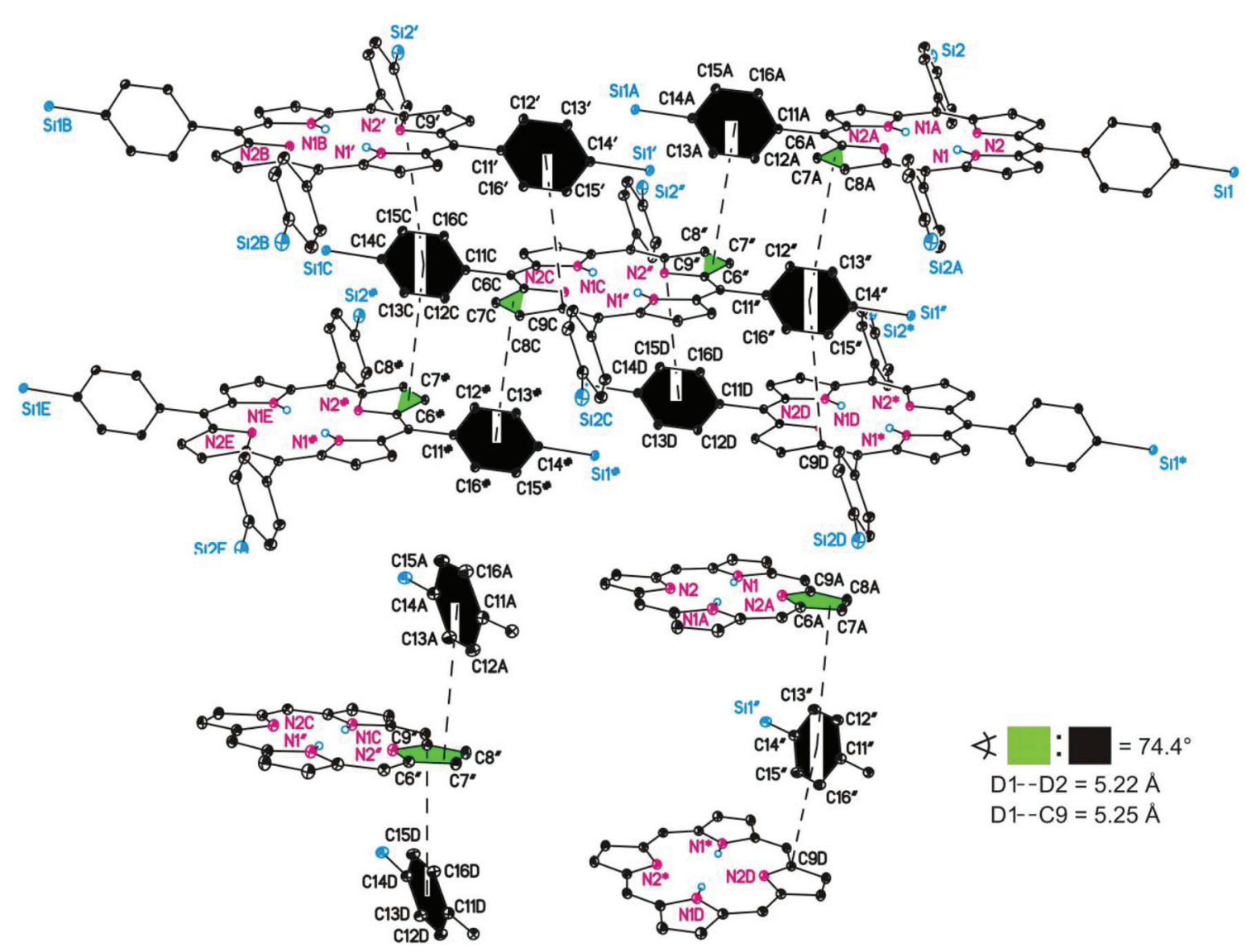

Fig. 7 Above: graphical illustration of a selected part of one 2D layer formed by $3 c$ due to intermolecular $\pi-\pi$ interactions. Labels ', ", * and \# refer to symmetry generated atoms of crystallographically independent molecules of the asymmetric unit of $3 c$, label A to symmetry generated atoms of the asymmetric unit of $3 \mathrm{c}$ and labels B-E to symmetry generated atoms of A labelled atoms. All C-bonded hydrogen atoms and terminal substituents at the silicon atoms are omitted for clarity. Below: graphical illustration of the intermolecular $\pi-\pi$ interactions between the aromatic $\mathrm{C}_{6} \mathrm{H}_{4}$ groups with the respective parts of the porphyrin core. The sign $\varangle$ refers to the calculated interplanar angles between differently coloured functionalities. Dotted lines indicate the shortest observed distances between the geometrical centroids of the $\mathrm{C}_{6} \mathrm{H}_{4}$ groups and the respective centroids/atoms of the porphyrin core with $\mathrm{D} 1=$ centroid of $\mathrm{C} 11-\mathrm{C} 16$ and $\mathrm{D} 2=$ centroid of $\mathrm{C} 6-\mathrm{C} 8$, respectively, and symmetry generated related atoms/fragments. 


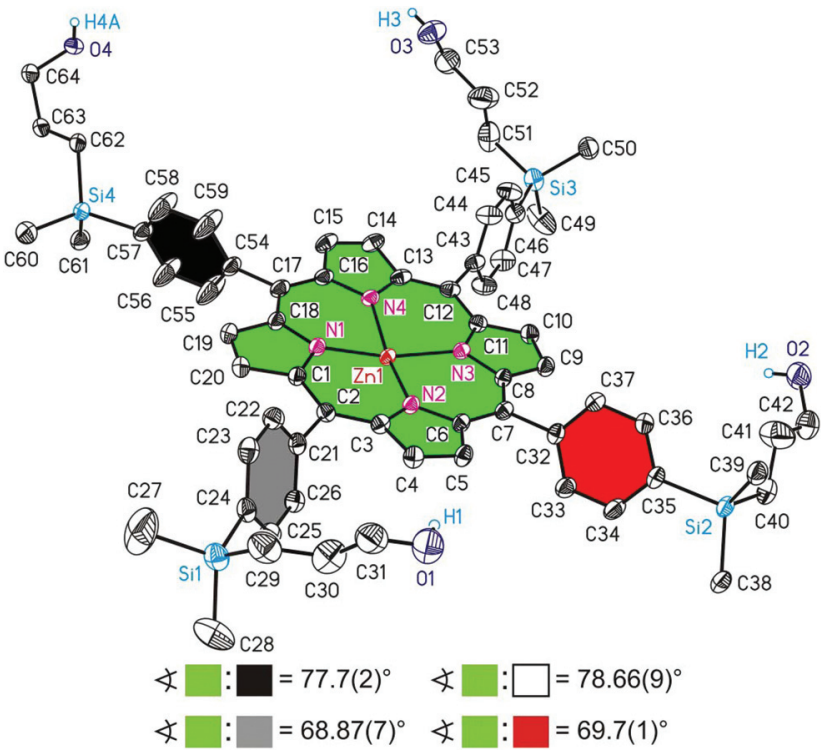

Fig. 8 ORTEP diagram (50\% ellipsoid probability) of the molecular structure of 6 a. All C-bonded hydrogen atoms are omitted for clarity. Of disordered atoms only one atomic position is displayed. The sign $\varangle$ refers to the calculated interplanar angles between terminal $\mathrm{C}_{6} \mathrm{H}_{4}$ groups and the central $\mathrm{C}_{20} \mathrm{~N}_{4} \mathrm{Zn}$ core.

T-shaped $\pi-\pi$ interactions is not a specific feature of the here reported porphyrins. There are already two crystallographically described meso-tetraphenylporphyrins known bearing terminal Si-functionalities at the para-position of the phenyl rings, namely 5,10,15,20-tetrakis(4-pentamethyldisilanyl)phenyl)porphyrin $^{32 a}$ and 5,10,15,20-tetrakis[4-(diethoxymethylsilyl)phenyl]porphyrin, ${ }^{32 b}$ which can be regarded as closely related to the here reported porphyrins. Bond lengths and angles of the $\mathrm{C}_{20} \mathrm{~N}_{4}$ porphyrin cores of these two reported samples are in very good agreement with the corresponding data observed for $\mathbf{3 b}, \mathbf{4 a}, \mathbf{6 a}$ and $\mathbf{9 b}$, respectively.

Especially for 5,10,15,20-tetrakis[4-(diethoxymethylsilyl)phenyl]porphyrin it is indicated that "no significant short contacts such as $\pi$-stacking" could be observed, which is attributed to the steric hindrance of the terminal silyl functionalities. ${ }^{32 b}$ It seems, however, likely, that only sandwich type $\pi-\pi$ interactions have been ruled out.

In the discussion of the crystal structures of $\mathrm{Zn}(\mathrm{TPP})$ and $\mathrm{Ag}$ (TPP) ${ }^{42}$ which are isomorphous to $\mathrm{H}_{2} \mathrm{TPP}$, T-shaped $\pi-\pi$ interactions have been explicitly mentioned. Interplanar angles between interacting aromatic units are given, although no centroid-to-centroid distances and the final type of assemblies formed have been mentioned. ${ }^{42}$ In the case of a report on the crystallographic characterisation of $\mathrm{Fe}(\mathrm{TPP})$ as a toluene solvate, the formation of $1 \mathrm{D}$ chains, due to sandwich type $\pi-\pi$ interactions, is observed. ${ }^{43}$ One can thus assume that for nonfunctionalised $\mathrm{M}(\mathrm{TPP})$ ( $\mathrm{M}=3 \mathrm{~d}$ metal ion) type porphyrins, especially for those in which the central metal ion is not coordinated by one and/or two donor molecules, $\pi-\pi$ interactions play a significant role in the crystal structures. Indeed, for

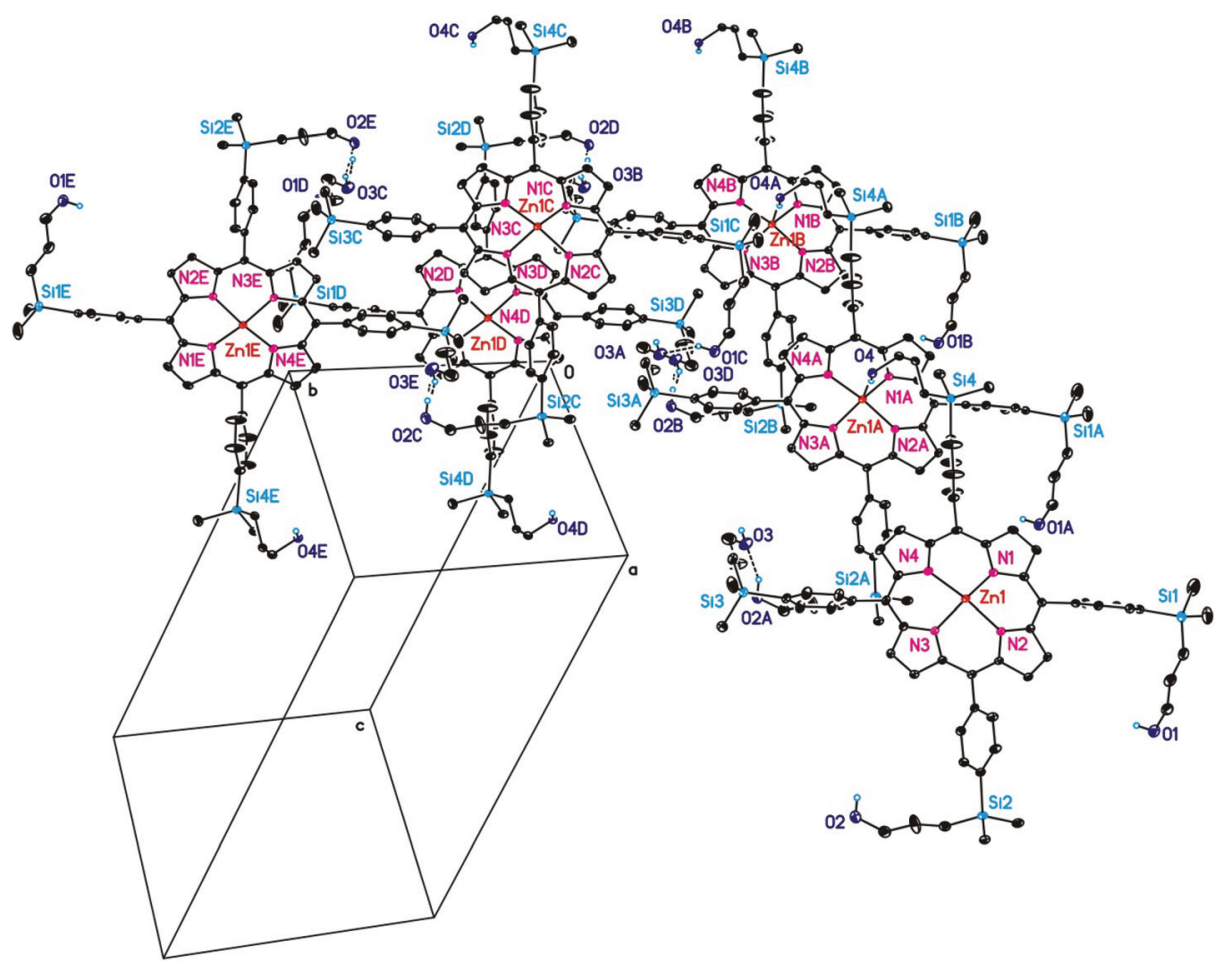

Fig. 9 Graphical representation of a part of one of the 2D layers formed by $6 \mathrm{a}$ in the solid state due to formation of intermolecular $\mathrm{O}-\mathrm{H} \cdots \mathrm{O}$ hydrogen bonds and $\mathrm{O}(\mathrm{H})-\mathrm{Zn}$ bonds. All C-bonded hydrogen atoms and packing solvent molecules are omitted for clarity. Of disordered atoms only one atomic position is displayed. Labels A-E refer to a $1^{\text {st }}-5^{\text {th }}$ symmetry generated molecule of $6 a$. 


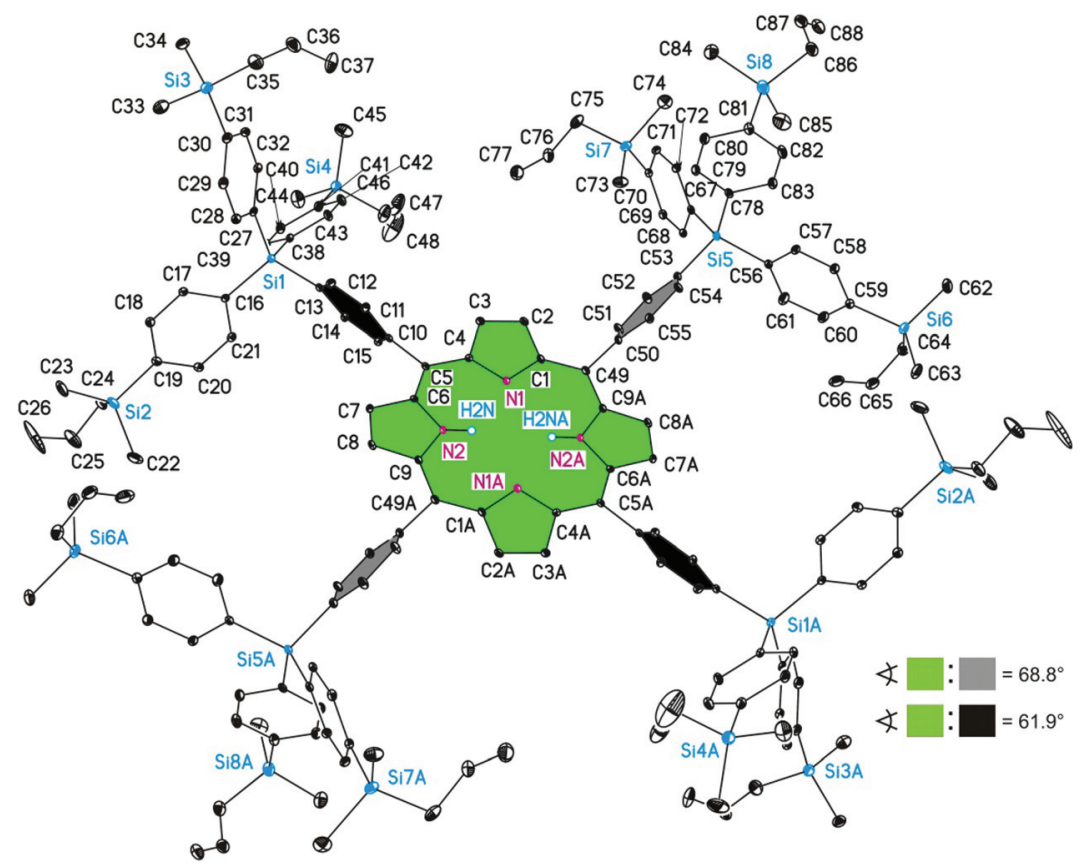

Fig. 10 ORTEP diagram (20\% ellipsoid probability) of the molecular structure of $9 \mathrm{bA}$. All carbon-bonded hydrogen atoms are omitted for clarity. Of disordered atoms only one atomic position is displayed. The sign $\Varangle$ refers to the calculated interplanar angles between the directly porphyrin bonded $\mathrm{C}_{6} \mathrm{H}_{4}$ groups and the central $\mathrm{C}_{20} \mathrm{~N}_{4} \mathrm{H}_{2}$ core. Symmetry code for $\mathrm{A}:-x+2,-y,-z$.

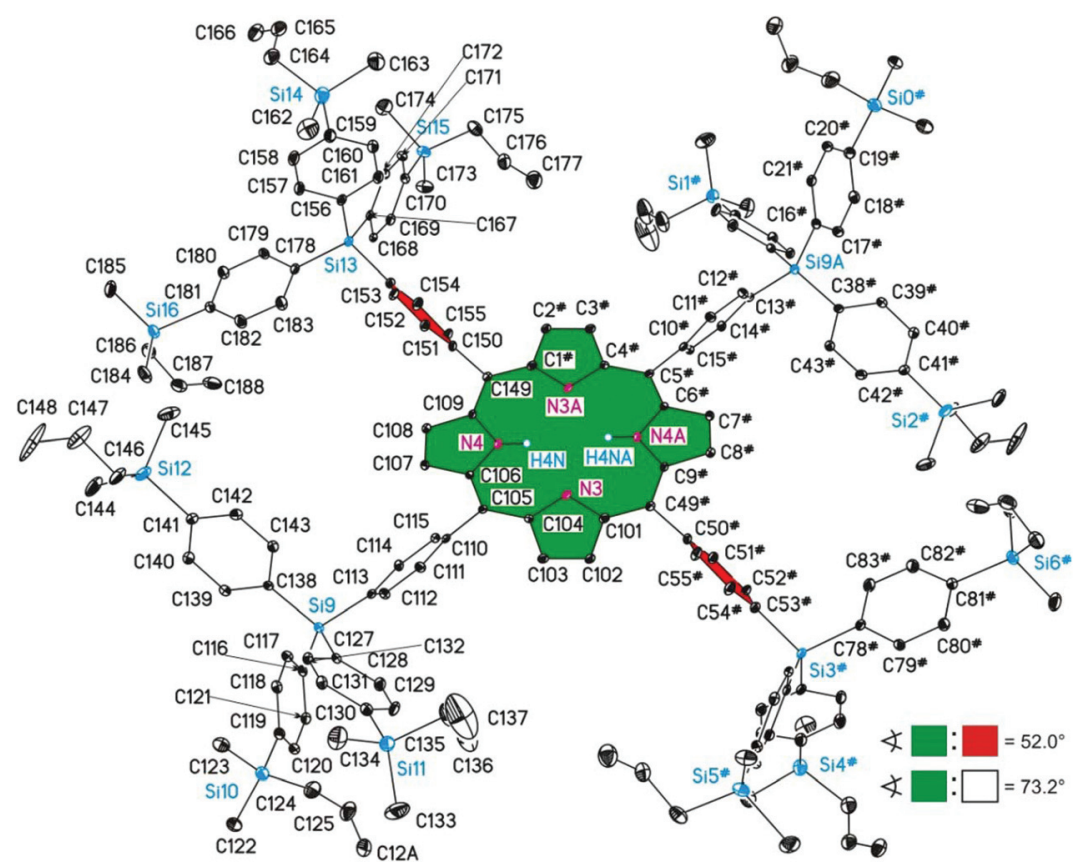

Fig. 11 ORTEP diagram ( $20 \%$ ellipsoid probability) of the molecular structure of $9 \mathrm{bB}$. All carbon-bonded hydrogen atoms are omitted for clarity. Of disordered atoms only one atomic position is displayed. The sign $\varangle$ refers to the calculated interplanar angles between the directly porphyrin bonded $\mathrm{C}_{6} \mathrm{H}_{4}$ groups and the central $\mathrm{C}_{20} \mathrm{~N}_{4} \mathrm{H}_{2}$ core. Symmetry code for $\mathrm{A}:-x+1,-y$ and for $\#:,-z+1 .{ }^{40 a}$

$\mathrm{Zn}$ (TPP), being co-crystallized with different guest molecules, a review by Byrn et al. $^{44}$ for over 200 different cases mentions explicitly the observation of intermolecular T-shaped $\pi-\pi$ interactions, although no geometrical features or types of assemblies were given.

\section{Conclusions}

The preparation of a series of $0^{\text {th }}$ and $1^{\text {st }}$ generation carbosilane dendrimer-based porphyrins of types $\mathrm{H}_{2} \mathrm{TPP}\left(4-\mathrm{SiRR}^{\prime} \mathrm{Me}\right)_{4}$, $\mathrm{Zn}(\mathrm{II})-\mathrm{TPP}\left(4-\mathrm{SiRR}^{\prime} \mathrm{Me}\right)_{4} \quad\left(\mathrm{R}=\mathrm{R}^{\prime}=\mathrm{Me}, \quad \mathrm{CH}_{2} \mathrm{CH}=\mathrm{CH}_{2}\right.$, 


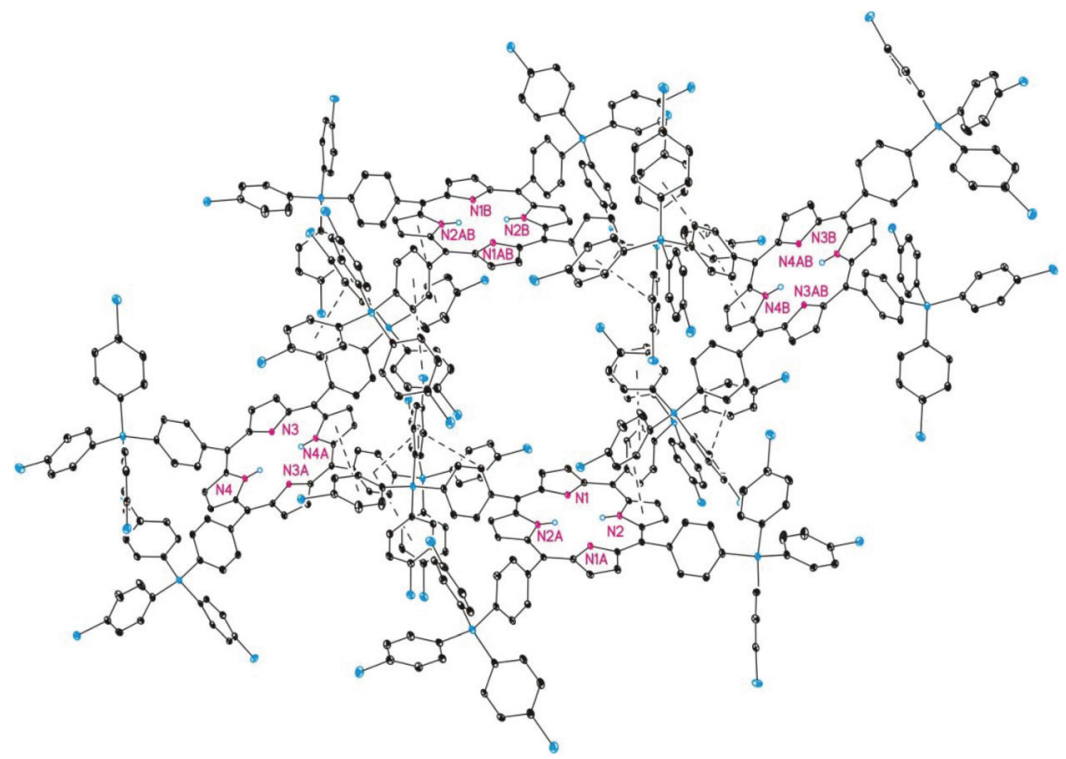

Fig. 12 Selected part of one $2 \mathrm{D}$ layer formed by $9 \mathrm{~b}$ in the solid state due to T-shaped $\pi-\pi$ interactions between molecules of $9 \mathrm{bA}$ and $9 \mathrm{bB}{ }^{40 b}$

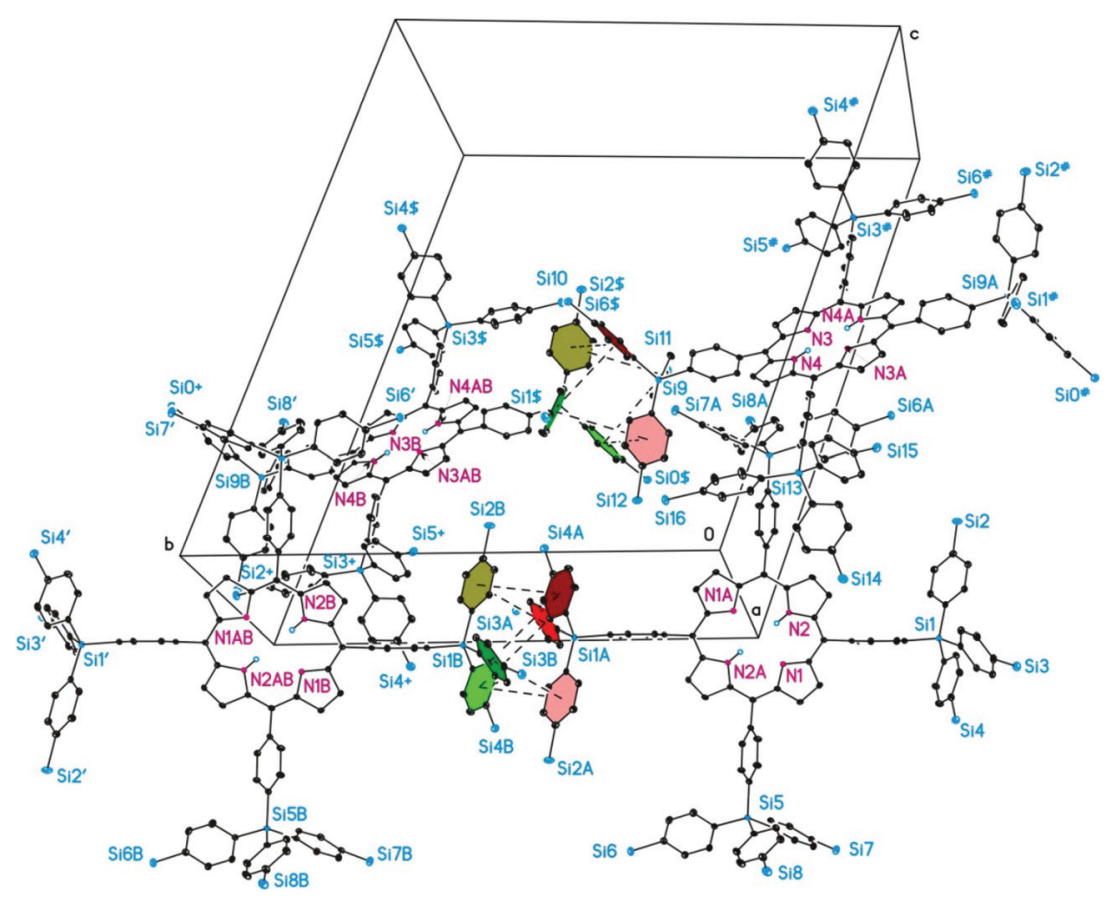

Fig. 13 Graphical illustration of the mutual T-shaped $\pi-\pi$ interactions between molecules of $9 b A$ and $9 b B$, being responsible for the connection of the $2 \mathrm{D}$ layers of $9 \mathrm{~b}$ to give a 3D network structure. ${ }^{40 b}$

$\mathrm{CH}_{2} \mathrm{CH}_{2} \mathrm{CH}_{2} \mathrm{OH} ; \mathrm{R}=\mathrm{Me}, \mathrm{R}^{\prime}=\mathrm{CH}_{2} \mathrm{CH}=\mathrm{CH}_{2}, \mathrm{CH}_{2} \mathrm{CH}_{2} \mathrm{CH}_{2} \mathrm{OH}$; $\mathrm{TPP}=$ tetraphenyl porphyrin $), \mathrm{H}_{2} \mathrm{TPP}\left(4-\mathrm{Si}\left(\mathrm{C}_{6} \mathrm{H}_{4}-1,4-\mathrm{SiRR}^{\prime}\right.\right.$ $\left.\mathrm{Me})_{3}\right)_{4}$, and $\mathrm{Zn}(\mathrm{II})-\mathrm{TPP}\left(4-\mathrm{Si}\left(\mathrm{C}_{6} \mathrm{H}_{4}-1,4-\mathrm{SiRR}^{\prime} \mathrm{Me}\right)_{3}\right)_{4}\left(\mathrm{R}=\mathrm{R}^{\prime}=\mathrm{Me}\right.$, $\mathrm{CH}_{2} \mathrm{CH}=\mathrm{CH}_{2} ; \mathrm{R}=\mathrm{Me}, \mathrm{R}^{\prime}=\mathrm{CH}_{2} \mathrm{CH}=\mathrm{CH}_{2}$ ) using the Lindsey condensation methodology is described. Functionalization of TPP with the carbosilane dendrons leads to a slight bathochromic shift of the Soret and $Q$ bands in the UV-Vis spectra, which is in agreement with the literature. ${ }^{30}$ The structures of five samples (3b,c, $\mathbf{4 a}, \mathbf{6 a}, \mathbf{9 b})$ in the solid state have been determined by single X-ray structure determination. The supramolecular structures of the allyl $0^{\text {th }}$ generation species $3 \mathbf{b}, \mathbf{c}, \mathbf{4 a}$ and the $1^{\text {st }}$ generation carbosilane-containing porphyrin $9 \mathrm{~b}$ are primarily controlled by $\pi-\pi$ interactions, while in the hydroxylfunctionalized porphyrin $\mathbf{6 a}$ the network formation is exclusively set by zinc-oxygen coordination and hydrogen bonding intermolecular interactions. Conspicuously, porphyrin $\mathbf{3 b}$ and its analogous zinc-metallated system $\mathbf{4 a}$ possess an identical 3D supramolecular structure as both compounds 


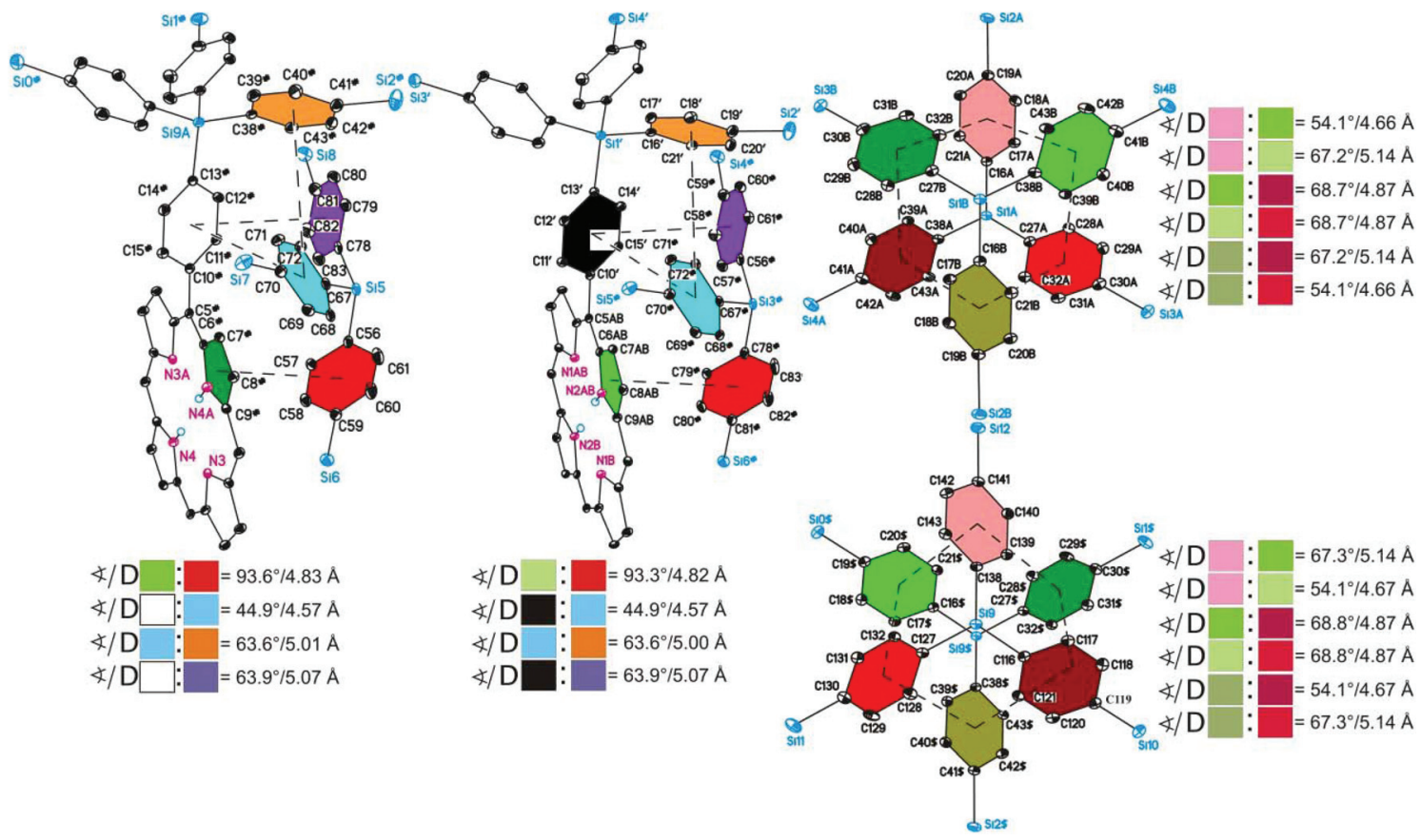

Fig. 14 Graphical illustration of the respective T-shaped $\pi-\pi$ interactions observed in the solid state structure of $9 \mathrm{~b}$ being responsible for the formation of 2D layers (left and middle) and for the interaction of 2D layers to give a 3D network. ${ }^{40 b}$

can be regarded as isomorphic in the solid state. On the other hand, the eight allyl groups in $\mathbf{3 c}$, instead of the four allyl units present in $\mathbf{3 b}$, modify the $3 \mathrm{D}$ network into a $2 \mathrm{D}$ network which might be responsible for the observation of significantly larger bond lengths of its $\mathrm{C}_{20} \mathrm{~N}_{4}$ core in comparison with the related bond lengths of the other here described porphyrins.

For meso-tetraphenylporphyrins bearing any kind of substituent at the phenyl rings it seems less likely that intermolecular sandwich type $\pi-\pi$ interactions can be observed, although T-shaped $\pi-\pi$ interactions might be found. For such cases we do not find, to the best of our knowledge, precise comments for crystallographically described representatives. We assume, however, that especially T-shaped $\pi-\pi$ interactions should be observed, as reported here for $\mathbf{3 b}, \mathbf{3} \mathbf{c}, \mathbf{4 a}$ and $\mathbf{9 b}$, at least in such cases where the central metal ions are not coordinated by additional donor solvents or the two $\mathrm{N}(H)$-protons of the central porphyrin rings are not involved in hydrogen bridges with protic donor solvents.

\section{Experimental section}

\section{General data}

All reactions were carried out under an atmosphere of nitrogen using standard Schlenk techniques. Tetrahydrofuran, toluene and ${ }^{n}$ pentane were purified by distillation from sodium-benzophenone ketyl; $\mathrm{CH}_{2} \mathrm{Cl}_{2}$ and $\mathrm{CHCl}_{3}$ were purified by distillation from calcium hydride. Diethylamine and diisopropylamine were distilled from $\mathrm{KOH}$; absolute $\mathrm{MeOH}$ was obtained by distillation from magnesium.

\section{Instrumentation}

Infrared spectra were recorded with a Perkin Elmer FT-IR spectrometer Spectrum $1000\left(\tilde{v}\right.$ in $\left.\mathrm{cm}^{-1}\right)$. UV-Vis spectra were measured with a Thermo Electron Corporation Genesys 6 spectrometer. NMR spectra were recorded with a Bruker Avance 250 spectrometer $\left({ }^{1} \mathrm{H}\right.$ NMR at $250.12 \mathrm{MHz}$ and ${ }^{13} \mathrm{C}\left\{{ }^{1} \mathrm{H}\right\}$ NMR at $62.86 \mathrm{MHz}$ ) in the Fourier transform mode. Chemical shifts are reported in $\delta$ units (parts per million) downfield from tetramethylsilane $(\delta=0.00 \mathrm{ppm})$ with the solvent as the reference signal $\left(\mathrm{CDCl}_{3}:{ }^{1} \mathrm{H} \mathrm{NMR}, \delta=7.26 ;{ }^{13} \mathrm{C}\left\{{ }^{1} \mathrm{H}\right\} \mathrm{NMR}, \delta=\right.$ 77.16; DMSO- $d_{6}$ : ${ }^{1} \mathrm{H}$ NMR, $\delta=2.54 ;{ }^{13} \mathrm{C}\left\{{ }^{1} \mathrm{H}\right\}$ NMR, $\delta=40.45$; thf- $d_{8}:{ }^{1} \mathrm{H}$ NMR, $\delta=1.72 ;{ }^{13} \mathrm{C}\left\{{ }^{1} \mathrm{H}\right\}$ NMR, $\left.\delta=24.45\right) .{ }^{45}$ The atom numbering is depicted in the ESI (Fig. S8 $\dagger$ ). The assignment of ${ }^{13} \mathrm{C}\left\{{ }^{1} \mathrm{H}\right\}$ and ${ }^{29} \mathrm{Si}\left\{{ }^{1} \mathrm{H}\right\}$ NMR spectroscopic signals is mainly based on ${ }^{13} \mathrm{C}$-DEPT-135 spectra and 2D-correlation spectra (gradient with sensitivity-enhanced heteronuclear multiple quantum correlation (gs-HMQC) for carbon and silicon and gradient with sensitivity-enhanced heteronuclear multiple bond correlation (gs-HMBC) for carbon). Please note that the resonance signal for the pyrrole- $\alpha-\mathrm{C}$ unit could only be detected for the zinc complexes under the measurement conditions applied. ESI-TOF mass spectra were recorded using a Mariner biospectrometry workstation 4.0 (Applied Biosystems). Microanalyses were performed with a Thermo FlashAE 1112 instrument. Melting points of pure samples were measured with Gallenkamp MFB 595010 equipment.

\section{Reagents}

1a, 2a, 3a, ${ }^{21} \mathbf{1 b},{ }^{22} 1 \mathbf{c}, 7 \mathbf{a}, \mathbf{c}^{24}{ }^{24} \mathbf{b}^{23}$ and $7 \mathbf{b}, \mathbf{8 b}, 9 \mathbf{b}^{18 a}$ were prepared according to published procedures. All other chemicals 
were purchased from commercial suppliers and were used as received.

\section{4-Diallylmethylsilylbenzaldehyde (2c)}

${ }^{t}$ BuLi (1.7 M, $34.7 \mathrm{mmol}, 20.4 \mathrm{~mL},{ }^{n}$ pentane) was added dropwise to a $\mathrm{Et}_{2} \mathrm{O}(75 \mathrm{~mL})$ solution containing 1c $(17.37 \mathrm{mmol}$, $4.88 \mathrm{~g}$ ) at $-78^{\circ} \mathrm{C}$. After $1 \mathrm{~h}$ of stirring at this temperature the resulting solution was drop-wise transferred via a cannula to dimethyl formamide (52.12 mmol, $3.81 \mathrm{~g}, 4.04 \mathrm{~mL})$ in thf $(50 \mathrm{~mL})$ at $0{ }^{\circ} \mathrm{C}$ and the obtained reaction mixture was kept at this temperature for $15 \mathrm{~min}$. Afterwards, it was warmed to ambient temperature, stirring was continued for $2 \mathrm{~h}$, and then it was quenched with aqueous $\mathrm{HCl}(3 \mathrm{~N}, 80 \mathrm{~mL})$. The obtained residue was extracted with $\mathrm{Et}_{2} \mathrm{O}(100 \mathrm{~mL})$ and the organic layer was washed with water $(2 \times 60 \mathrm{~mL})$, saturated $\mathrm{NaHCO}_{3}(60 \mathrm{~mL})$ and brine $(60 \mathrm{~mL})$ and was then dried over $\mathrm{MgSO}_{4}$. Afterwards, all volatiles were removed in oil-pump vacuum. The crude product was purified by column chromatography (a) ${ }^{n}$ hexane, (b) 20 vol\% $\mathrm{CH}_{2} \mathrm{Cl}_{2}{ }^{-}{ }^{n}$ hexane to afford $2 \mathrm{c}$ as colorless oil (14.86 mmol, $3.42 \mathrm{~g}$, 86\% based on 1c).

IR (film): $\tilde{v}=3074,3024,2992,2966,2910,2882,2824(\mathrm{w}$, CHO), 2732 (w, CHO), 1704 (s, C=O), 1630 (w, C=C), 1254 (w, $\mathrm{CH}_{3}$ bending), 808 (s, SiC). ${ }^{1} \mathrm{H}$ NMR $\left(\mathrm{CDCl}_{3}\right): \delta=10.02(\mathrm{~s}, 1 \mathrm{H}$, $\mathrm{CHO}), 7.84\left(\mathrm{dt}, J_{\mathrm{HH}}=8.1 \mathrm{~Hz}, J_{\mathrm{HH}}=1.6 \mathrm{~Hz}, 2 \mathrm{H}, \mathrm{H}^{3}\right), 7.68(\mathrm{dt}$, $\left.J_{\mathrm{HH}}=8.1 \mathrm{~Hz}, 1.6 \mathrm{~Hz}, 2 \mathrm{H}, \mathrm{H}^{4}\right), 5.74\left(\mathrm{ddt}, J_{\mathrm{HH}}=17.6 \mathrm{~Hz}, J_{\mathrm{HH}}=\right.$ $\left.9.5 \mathrm{~Hz}, J_{\mathrm{HH}}=8.1 \mathrm{~Hz}, 2 \mathrm{H}, \mathrm{H}^{8}\right), 4.89\left(\mathrm{ddt}, J_{\mathrm{HH}}=17.6 \mathrm{~Hz}, J_{\mathrm{HH}}=\right.$ $2.0 \mathrm{~Hz}, J_{\mathrm{HH}}=1.1 \mathrm{~Hz}, 2 \mathrm{H}$, cis $\left.-\mathrm{H}^{9}\right), 4.88\left(\mathrm{ddt}, J_{\mathrm{HH}}=9.5 \mathrm{~Hz}, J_{\mathrm{HH}}=\right.$ $2.0 \mathrm{~Hz}, J_{\mathrm{HH}}=1.1 \mathrm{~Hz}, 2 \mathrm{H}$, trans $\left.-\mathrm{H}^{9}\right), 1.84\left(\mathrm{dt}, J_{\mathrm{HH}}=8.1 \mathrm{~Hz}, J_{\mathrm{HH}}\right.$ $\left.=1.1 \mathrm{~Hz}, 4 \mathrm{H}, \mathrm{H}^{7}\right), 0.34\left(\mathrm{~s}, 3 \mathrm{H}, \mathrm{H}^{6}\right) .{ }^{13} \mathrm{C}\left\{{ }^{1} \mathrm{H}\right\} \operatorname{NMR}\left(\mathrm{CDCl}_{3}\right): \delta=$ $192.4\left(1 \mathrm{C}^{1}\right), 145.5\left(1 \mathrm{C}^{5}\right), 136.7\left(1 \mathrm{C}^{2}\right), 134.4\left(2 \mathrm{C}^{4}\right), 133.4$ $\left(2 \mathrm{C}^{8}\right), 128.5\left(2 \mathrm{C}^{3}\right), 114.4\left(2 \mathrm{C}^{9}\right), 21.2\left(2 \mathrm{C}^{7}\right),-6.1\left(1 \mathrm{C}^{6}\right)$. ${ }^{29} \mathrm{Si}\left\{{ }^{1} \mathrm{H}\right\}$ NMR $\left(\mathrm{CDCl}_{3}\right): \delta=-5.0$. ESI-TOF: $\mathrm{m} / \mathrm{z}=231.10$ $[\mathrm{M}+\mathrm{H}]^{+}$(calcd 231.12). Anal. calcd for $\mathrm{C}_{14} \mathrm{H}_{18} \mathrm{OSi}$ (230.38): C, 72.99; H, 7.88. Found: C, 72.54; H, 7.51.

\section{meso-Tetrakis(4-allyldimethylsilylphenyl)porphyrin (3b)}

To aldehyde $2 \mathbf{b}$ (6.00 mmol, $1.224 \mathrm{~g})$ and pyrrole $(6.00 \mathrm{mmol}$, $0.403 \mathrm{~g}, 0.416 \mathrm{~mL})$ dissolved in $\mathrm{CH}_{2} \mathrm{Cl}_{2}(600 \mathrm{~mL}),\left[\mathrm{BF}_{3} \cdot \mathrm{OEt}_{2}\right]$ ( $0.60 \mathrm{mmol}, 0.085 \mathrm{~g}, 0.076 \mathrm{~mL}$ ) was added in a single portion. The reaction solution was stirred for $2 \mathrm{~h}$ at ambient temperature and then 2,3-dichloro-5,6-dicyanobenzoquinone (4.50 mmol, $1.224 \mathrm{~g}$ ) was added in a single portion and stirring was continued for $1 \mathrm{~h}$. The reaction mixture was washed with saturated $\mathrm{NaHCO}_{3}(100 \mathrm{~mL})$ and then with water $(3 \times 100 \mathrm{~mL})$. The organic layer was filtered through a pad of silica gel and afterwards all volatiles were removed in oil-pump vacuum. The obtained solid material was purified by column chromatography (a) ${ }^{n}$ hexane and (b) 20 vol\% $\mathrm{CH}_{2} \mathrm{Cl}_{2}-{ }^{n}$ hexane. Porphyrin 3b was obtained as a dark red solid (0.44 mmol, $0.44 \mathrm{~g}, 29 \%$ based on $\mathbf{2 b}$ ).

$\mathrm{Mp}=350{ }^{\circ} \mathrm{C}$ (dec). IR ( $\mathrm{KBr}$ disc): $\tilde{v}=3315$ (s, NH), 3069, 3056, 3011, 2994, 2911, 2880, 1627 (w, C=C), 1251 (m, $\mathrm{CH}_{3}$ bending), 834, 818, 804 (s, SiC). ${ }^{1} \mathrm{H} \mathrm{NMR}\left(\mathrm{CDCl}_{3}\right): \delta=8.87(\mathrm{~s}$, $\left.8 \mathrm{H}, \mathrm{H}^{1}\right), 8.23\left(\mathrm{brd}, J_{\mathrm{HH}}=7.9 \mathrm{~Hz}, 8 \mathrm{H}, \mathrm{H}^{5}\right), 7.90\left(\mathrm{brd}, J_{\mathrm{HH}}=\right.$ $\left.7.9 \mathrm{~Hz}, 8 \mathrm{H}, \mathrm{H}^{6}\right), 6.01\left(\mathrm{ddt}, J_{\mathrm{HH}}=17.0 \mathrm{~Hz}, J_{\mathrm{HH}}=10.1 \mathrm{~Hz}, J_{\mathrm{HH}}=\right.$ $\left.8.1 \mathrm{~Hz}, 4 \mathrm{H}, \mathrm{H}^{10}\right), 5.04\left(\mathrm{ddt}, J_{\mathrm{HH}}=17.0 \mathrm{~Hz}, J_{\mathrm{HH}}=2.4 \mathrm{~Hz}, J_{\mathrm{HH}}=\right.$
$1.1 \mathrm{~Hz}, 4 \mathrm{H}$, cis $\left.-\mathrm{H}^{11}\right), 5.01\left(\mathrm{ddt}, J_{\mathrm{HH}}=10.1 \mathrm{~Hz}, J_{\mathrm{HH}}=2.4 \mathrm{~Hz}\right.$, $J_{\mathrm{HH}}=1.1 \mathrm{~Hz}, 3 \mathrm{H}$, trans $\left.-\mathrm{H}^{11}\right), 2.02\left(\mathrm{dt}, J_{\mathrm{HH}}=8.1 \mathrm{~Hz}, J_{\mathrm{HH}}=\right.$ $1.1 \mathrm{~Hz}, 16 \mathrm{H}, \mathrm{H}^{9}$ ), 0.54 (s, $24 \mathrm{H}, \mathrm{H}^{8}$ ), -2.74 (brs, $\left.2 \mathrm{H}, \mathrm{NH}\right) .{ }^{13} \mathrm{C}$ $\left\{{ }^{1} \mathrm{H}\right\} \operatorname{NMR}\left(\mathrm{CDCl}_{3}\right): \delta=142.8\left(4 \mathrm{C}^{7}\right), 137.8\left(4 \mathrm{C}^{4}\right), 134.7\left(4 \mathrm{C}^{10}\right)$, $134.1\left(8 \mathrm{C}^{6}\right), 132.0\left(8 \mathrm{C}^{5}\right), 131.2$ (br, $\left.8 \mathrm{C}^{1}\right), 120.1\left(4 \mathrm{C}^{3}\right), 113.6$ $\left(4 \mathrm{C}^{11}\right), 24.0\left(4 \mathrm{C}^{9}\right),-3.2\left(8 \mathrm{C}^{8}\right) .{ }^{29} \mathrm{Si}\left\{{ }^{1} \mathrm{H}\right\} \mathrm{NMR}\left(\mathrm{CDCl}_{3}\right): \delta=-4.1$. ESI-TOF: $m / z=1007.49[\mathrm{M}+\mathrm{H}]^{+}$(calcd 1007.48). Anal. calcd for $\mathrm{C}_{64} \mathrm{H}_{70} \mathrm{~N}_{4} \mathrm{Si}_{4}$ (1007.61): C, 76.29; H, 7.00; N, 5.56. Found: C, 76.03; H, 7.26; N, 5.30.

\section{meso-Tetrakis(4-diallylmethylsilylphenyl)porphyrin (3c)}

To aldehyde 2c $(10.00 \mathrm{mmol}, 2.301 \mathrm{~g})$ and pyrrole (10.00 mmol, $0.671 \mathrm{~g}, 0.69 \mathrm{~mL})$ dissolved in $\mathrm{CH}_{2} \mathrm{Cl}_{2}(1000 \mathrm{~mL})$ $\left[\mathrm{BF}_{3} \cdot \mathrm{OEt}_{2}\right](1.00 \mathrm{mmol}, 0.142 \mathrm{~g}, 0.13 \mathrm{~mL})$ was added in a single portion. The reaction solution was stirred for $2 \mathrm{~h}$ and then 2,3dichloro-5,6-dicyanobenzoquinone (7.50 mmol, $1.703 \mathrm{~g}$ ) was added in a single portion and stirring was continued for $1 \mathrm{~h}$. The reaction mixture was washed with saturated $\mathrm{NaHCO}_{3}$ $(100 \mathrm{~mL})$ and then with water $(3 \times 100 \mathrm{~mL})$. The organic layer was filtered through a pad of silica gel and afterwards all volatiles were removed in oil-pump vacuum. The crude product was purified by column chromatography (a) ${ }^{n}$ hexane and (b) 20 vol\% $\mathrm{CH}_{2} \mathrm{Cl}_{2}{ }^{-}{ }^{n}$ hexane. Porphyrin $3 \mathrm{c}$ was obtained as a dark red solid ( $0.69 \mathrm{mmol}, 0.76 \mathrm{~g}, 27 \%$ based on $2 \mathrm{c}$ ).

$\mathrm{Mp}=350{ }^{\circ} \mathrm{C}$ (dec). IR (KBr disc): $\tilde{v}=3314(\mathrm{~s}, \mathrm{NH}), 3070$, 3006, 2994, 2966, 2912, 2880, $1628(\mathrm{~m}, \mathrm{C}=\mathrm{C}), 1250\left(\mathrm{~m}, \mathrm{CH}_{3}\right.$ bending), 800 (s, SiC). ${ }^{1} \mathrm{H}$ NMR $\left(\mathrm{CDCl}_{3}\right): \delta=8.90\left(\mathrm{~s}, 8 \mathrm{H}, \mathrm{H}^{1}\right)$, $8.26\left(\mathrm{brd}, J_{\mathrm{HH}}=7.9 \mathrm{~Hz}, 8 \mathrm{H}, \mathrm{H}^{5}\right), 7.92\left(\mathrm{brd}, J_{\mathrm{HH}}=7.9 \mathrm{~Hz}, 8 \mathrm{H}\right.$, $\left.\mathrm{H}^{6}\right), 6.04\left(\mathrm{ddt}, J_{\mathrm{HH}}=17.0 \mathrm{~Hz}, J_{\mathrm{HH}}=10.1 \mathrm{~Hz}, J_{\mathrm{HH}}=8.1 \mathrm{~Hz}, 8 \mathrm{H}\right.$, $\left.\mathrm{H}^{10}\right), 5.10\left(\mathrm{ddt}, J_{\mathrm{HH}}=17.0 \mathrm{~Hz}, J_{\mathrm{HH}}=2.0 \mathrm{~Hz}, J_{\mathrm{HH}}=0.9 \mathrm{~Hz}, 8 \mathrm{H}\right.$, cis- $\left.\mathrm{H}^{11}\right), 5.06\left(\mathrm{ddt}, J_{\mathrm{HH}}=10.1 \mathrm{~Hz}, J_{\mathrm{HH}}=2.0 \mathrm{~Hz}, J_{\mathrm{HH}}=0.9 \mathrm{~Hz}\right.$, $8 \mathrm{H}$, trans $\left.-\mathrm{H}^{11}\right), 2.10\left(\mathrm{dt}, J_{\mathrm{HH}}=8.0 \mathrm{~Hz}, J_{\mathrm{HH}}=0.9 \mathrm{~Hz}, 32 \mathrm{H}, \mathrm{H}^{9}\right)$, 0.58 (s, $\left.24 \mathrm{H}, \mathrm{H}^{8}\right),-2.69$ (brs, $\left.2 \mathrm{H}, \mathrm{NH}\right) .{ }^{13} \mathrm{C}\left\{{ }^{1} \mathrm{H}\right\} \mathrm{NMR}\left(\mathrm{CDCl}_{3}\right)$ : $\delta=142.9\left(4 \mathrm{C}^{7}\right), 136.1\left(4 \mathrm{C}^{4}\right), 134.3\left(8 \mathrm{C}^{10}\right), 134.1\left(8 \mathrm{C}^{6}\right), 132.3$ $\left(8 \mathrm{C}^{5}\right), 131.1$ (br, $\left.8 \mathrm{C}^{1}\right), 120.1\left(4 \mathrm{C}^{3}\right), 114.1\left(8 \mathrm{C}^{11}\right), 21.8\left(8 \mathrm{C}^{9}\right)$, $-5.6\left(4 \mathrm{C}^{8}\right) .{ }^{29} \mathrm{Si}\left\{{ }^{1} \mathrm{H}\right\}$ NMR $\left(\mathrm{CDCl}_{3}\right): \delta=-5.2$. ESI-TOF: $m / z=$ $1111.50[\mathrm{M}+\mathrm{H}]^{+}$(calcd 1111.54). Anal. calcd for $\mathrm{C}_{72} \mathrm{H}_{78} \mathrm{~N}_{4} \mathrm{Si}_{4}$ (1111.53): C, 77.78; H, 7.07; N, 5.04. Found: C, 77.68; H, 6.59; $\mathrm{N}, 4.80$.

\section{meso-Tetrakis(4-allyldimethylsilylphenyl)porphyrinato zinc} (4a)

To $3 \mathbf{b}(0.050 \mathrm{mmol}, 0.0504 \mathrm{~g})$ dissolved in $\mathrm{CHCl}_{3}(15 \mathrm{~mL})$, a $\mathrm{MeOH}$ solution $(10 \mathrm{~mL})$ containing $\left[\mathrm{Zn}(\mathrm{OAc})_{2} \cdot 2 \mathrm{H}_{2} \mathrm{O}\right]$ $(0.100 \mathrm{mmol}, 0.0219 \mathrm{~g})$ was added in a single portion. The reaction solution was stirred for $2 \mathrm{~h}$ at ambient temperature and was then washed with saturated $\mathrm{NaHCO}_{3}(15 \mathrm{~mL})$ followed by washing with water $(2 \times 15 \mathrm{~mL})$. The organic layer was dried over $\mathrm{Na}_{2} \mathrm{SO}_{4}$. All volatiles were removed in oil-pump vacuum to afford $4 \mathrm{a}$ as a dark red solid (0.495 mmol, $0.053 \mathrm{~g}$, 99\% based on $3 \mathbf{b})$.

$\mathrm{Mp}=350{ }^{\circ} \mathrm{C}(\mathrm{dec}) . \mathrm{IR}(\mathrm{KBr}$ disc): $\tilde{v}=3055,3011,2989,2911$, 2954, 2908, 2878, 1627 (w, $\mathrm{C}=\mathrm{C}$ ), 125 ( $\mathrm{m}, \mathrm{CH}_{3}$ bending), 836, 820, 811, 796 (s, SiC). ${ }^{1} \mathrm{H}$ NMR $\left(\mathrm{CDCl}_{3}\right): \delta=9.00\left(\mathrm{~s}, 8 \mathrm{H}, \mathrm{H}^{1}\right)$, $8.25\left(\mathrm{brd}, J_{\mathrm{HH}}=7.9 \mathrm{~Hz}, 8 \mathrm{H}, \mathrm{H}^{5}\right), 7.90\left(\mathrm{brd}, J_{\mathrm{HH}}=7.9 \mathrm{~Hz}, 8 \mathrm{H}\right.$, $\left.\mathrm{H}^{6}\right), 6.02\left(\mathrm{ddt}, J_{\mathrm{HH}}=17.0 \mathrm{~Hz}, J_{\mathrm{HH}}=10.1 \mathrm{~Hz}, J_{\mathrm{HH}}=8.1 \mathrm{~Hz}, 4 \mathrm{H}\right.$, 
$\left.\mathrm{H}^{10}\right), 5.05\left(\mathrm{brd}, J_{\mathrm{HH}}=17.0 \mathrm{~Hz}, 4 \mathrm{H}\right.$, cis- $\left.\mathrm{H}^{11}\right), 5.02\left(\mathrm{brd}, J_{\mathrm{HH}}=\right.$ $10.1 \mathrm{~Hz}, 4 \mathrm{H}$, trans $\left.-\mathrm{H}^{11}\right), 2.03\left(\mathrm{brd}, J_{\mathrm{HH}}=8.1 \mathrm{~Hz}, 8 \mathrm{H}, \mathrm{H}^{9}\right), 0.56$ $\left(\mathrm{s}, 24 \mathrm{H}, \mathrm{H}^{8}\right) \cdot{ }^{13} \mathrm{C}\left\{{ }^{1} \mathrm{H}\right\} \operatorname{NMR}\left(\mathrm{CDCl}_{3}\right): \delta=150.2\left(4 \mathrm{C}^{2}\right), 143.4$ $\left(4 \mathrm{C}^{7}\right), 137.5\left(4 \mathrm{C}^{4}\right), 134.8\left(4 \mathrm{C}^{10}\right), 133.9\left(8 \mathrm{C}^{6}\right), 132.1\left(8 \mathrm{C}^{1}\right)$, $131.8\left(8 \mathrm{C}^{5}\right), 121.2\left(4 \mathrm{C}^{3}\right), 113.6\left(4 \mathrm{C}^{11}\right), 24.0\left(4 \mathrm{C}^{9}\right),-3.2\left(8 \mathrm{C}^{8}\right)$. ${ }^{29} \mathrm{Si}\left\{{ }^{1} \mathrm{H}\right\}$ NMR $\left(\mathrm{CDCl}_{3}\right): \delta=-4.1$ (4 Si). ESI-TOF: $m / z=1070.44$ $[\mathrm{M}]^{+}$(calcd 1070.40). Anal. calcd for $\mathrm{C}_{64} \mathrm{H}_{70} \mathrm{~N}_{4} \mathrm{Si}_{4} \mathrm{Zn}$ (1073.00): C, 71.64; H, 6.58; N, 5.22. Found: C, 71.44; H, 6.58; N, 4.98.

\section{meso-Tetrakis[4-(diallylmethylsilyl)phenyl]porphyrinato zinc} (4b)

To porphyrin 3c $(0.050 \mathrm{mmol}, 0.0556 \mathrm{~g})$ dissolved in $\mathrm{CHCl}_{3}$ $(15 \mathrm{~mL}),\left[\mathrm{Zn}(\mathrm{OAc})_{2} \cdot 2 \mathrm{H}_{2} \mathrm{O}\right](0.100 \mathrm{mmol}, 0.0219 \mathrm{~g})$ dissolved in $\mathrm{MeOH}(10 \mathrm{~mL})$ was added in a single portion. The reaction solution was stirred for $2 \mathrm{~h}$ at ambient temperature and afterwards it was washed with saturated $\mathrm{NaHCO}_{3}(15 \mathrm{~mL})$ and then with water $(2 \times 15 \mathrm{~mL})$. The organic layer was dried over $\mathrm{Na}_{2} \mathrm{SO}_{4}$ and all volatiles were removed in oil-pump vacuum to afford $4 \mathbf{b}$ as a dark red solid (0.490 mmol, $0.0576 \mathrm{~g}, 98 \%$ based on $3 \mathbf{c})$.

$\mathrm{Mp}=350^{\circ} \mathrm{C}(\mathrm{dec}) . \mathrm{IR}(\mathrm{KBr}$ disc): $\tilde{v}=3070,3056,3008,2990$, 2966, 2952, 2912, 2876, $1628(\mathrm{~m}, \mathrm{C}=\mathrm{C}), 1252\left(\mathrm{~m}, \mathrm{SiCH}_{3}\right.$ bending), 820 (s, SiC), 798 (s, SiC). ${ }^{1} \mathrm{H} \mathrm{NMR}\left(\mathrm{CDCl}_{3}\right): \delta=8.98$ $\left(\mathrm{s}, 8 \mathrm{H}, \mathrm{H}^{1}\right), 8.24$ (brd, $\left.J_{\mathrm{HH}}=7.9 \mathrm{~Hz}, 8 \mathrm{H}, \mathrm{H}^{5}\right), 7.89\left(\mathrm{brd}, J_{\mathrm{HH}}=\right.$ $\left.7.9 \mathrm{~Hz}, 8 \mathrm{H}, \mathrm{H}^{6}\right), 6.01\left(\mathrm{ddt}, J_{\mathrm{HH}}=17.0 \mathrm{~Hz}, J_{\mathrm{HH}}=10.1 \mathrm{~Hz}, J_{\mathrm{HH}}=\right.$ $\left.8.1 \mathrm{~Hz}, 8 \mathrm{H}, \mathrm{H}^{10}\right), 5.07\left(\mathrm{ddt}, J_{\mathrm{HH}}=17.0 \mathrm{~Hz}, J_{\mathrm{HH}}=2.0 \mathrm{~Hz}, J_{\mathrm{HH}}=\right.$ $0.9 \mathrm{~Hz}, 4 \mathrm{H}$, cis $\left.-\mathrm{H}^{11}\right), 5.03\left(\mathrm{ddt}, J_{\mathrm{HH}}=10.1 \mathrm{~Hz}, J_{\mathrm{HH}}=2.0 \mathrm{~Hz}\right.$, $J_{\mathrm{HH}}=0.9 \mathrm{~Hz}, 4 \mathrm{H}$, trans $\left.-\mathrm{H}^{11}\right), 2.02\left(\mathrm{dt}, J_{\mathrm{HH}}=8.1 \mathrm{~Hz}, J_{\mathrm{HH}}=\right.$ $\left.0.9 \mathrm{~Hz}, 16 \mathrm{H}, \mathrm{H}^{9}\right), 0.55\left(\mathrm{~s}, 12 \mathrm{H}, \mathrm{H}^{8}\right) .{ }^{13} \mathrm{C}\left\{{ }^{1} \mathrm{H}\right\} \mathrm{NMR}\left(\mathrm{CDCl}_{3}\right): \delta=$ $150.1\left(4 \mathrm{C}^{2}\right), 143.6\left(4 \mathrm{C}^{7}\right), 135.8\left(4 \mathrm{C}^{4}\right), 134.3\left(8 \mathrm{C}^{10}\right), 133.9$ $\left(8 \mathrm{C}^{6}\right), 132.2\left(8 \mathrm{C}^{5}\right), 132.0\left(8 \mathrm{C}^{1}\right), 121.1\left(4 \mathrm{C}^{3}\right), 114.1\left(8 \mathrm{C}^{11}\right)$, $21.9\left(8 \mathrm{C}^{9}\right),-5.6\left(4 \mathrm{C}^{8}\right) .{ }^{29} \mathrm{Si}\left\{{ }^{1} \mathrm{H}\right\}$ NMR $\left(\mathrm{CDCl}_{3}\right): \delta=-5.2$. ESI-TOF: $m / z=1174.48[\mathrm{M}]^{+}$(calcd 1174.46). Anal. calcd for $\mathrm{C}_{72} \mathrm{H}_{78} \mathrm{~N}_{4} \mathrm{Si}_{4} \mathrm{Zn}$ (1177.15): C, 73.46; H, 6.68; N, 4.76. Found: C, 73.24; H, 6.45; N, 4.68 .

\section{meso-Tetrakis[4-dimethyl(3-hydroxypropyl)silylphenyl]- porphyrin (5a)}

To $\left[\mathrm{BH}_{3} \cdot \mathrm{SMe}_{2}\right](2.0 \mathrm{M}, 2.00 \mathrm{mmol}, 1.00 \mathrm{~mL})$ dissolved in thf $(5.0 \mathrm{~mL}), 3 \mathrm{~b}(0.397 \mathrm{mmol}, 0.400 \mathrm{~g})$ in thf $(30 \mathrm{~mL})$ was dropwise added over $10 \mathrm{~min}$ at $0{ }^{\circ} \mathrm{C}$. The reaction solution was stirred for $2 \mathrm{~h}$ at this temperature and afterwards it was quenched with aqueous $\mathrm{NaOH}(3 \mathrm{M}, 0.75 \mathrm{~mL})$ and stirring was continued for $15 \mathrm{~min}$. Afterwards, $\mathrm{H}_{2} \mathrm{O}_{2}(30 \%, 0.75 \mathrm{~mL})$ was added in a single portion, stirring was continued at ambient temperature for $30 \mathrm{~min}$ and then the reaction mixture was extracted with saturated aqueous $\mathrm{K}_{2} \mathrm{CO}_{3}(20 \mathrm{~mL})$ and with a $\mathrm{Et}_{2} \mathrm{O}$-thf mixture (ratio $1: 1, \mathrm{v} / \mathrm{v} ; 50 \mathrm{~mL}$ ). The organic layer was washed with brine and filtered through a silica gel column (thf, column size $1.0 \times 10 \mathrm{~cm}$ ). From the eluate, all volatiles were removed in oil-pump vacuum and the residue was washed with $\mathrm{Et}_{2} \mathrm{O}(3 \times 15 \mathrm{~mL})$ and was then dried in oil-pump vacuum to give $5 \mathbf{a}(0.332 \mathrm{mmol}, 0.358 \mathrm{~g}, 83 \%$ based on $\mathbf{3 b}$ ) as a dark red solid.

$\mathrm{Mp}=350{ }^{\circ} \mathrm{C}$ (dec). IR (KBr disc): $\tilde{v}=3397$ (s, OH), $3314(\mathrm{~s}$, $\mathrm{NH}$ ), 3055, 3011, 2994, 2926, 2864, 1251 (m, $\mathrm{CH}_{3}$ bending),
833, 803 (s, SiC). ${ }^{1} \mathrm{H}$ NMR (dmso- $\left.d_{6}\right): \delta=8.85\left(\mathrm{~s}, 8 \mathrm{H}, \mathrm{H}^{1}\right), 8.23$ $\left(\mathrm{d}, J_{\mathrm{HH}}=7.4 \mathrm{~Hz}, 8 \mathrm{H}, \mathrm{H}^{5}\right), 7.96\left(\mathrm{~d}, J_{\mathrm{HH}}=7.3 \mathrm{~Hz}, 8 \mathrm{H}, \mathrm{H}^{6}\right), 4.53$ $\left(\mathrm{t}, J_{\mathrm{HH}}=5.3 \mathrm{~Hz}, 4 \mathrm{H}, \mathrm{OH}\right), 3.51\left(\mathrm{q}, J_{\mathrm{HH}}=6.2 \mathrm{~Hz}, 8 \mathrm{H}, \mathrm{H}^{11}\right), 1.67$ $\left(\mathrm{m}, 8 \mathrm{H}, \mathrm{H}^{10}\right), 0.96\left(\mathrm{~m}, 8 \mathrm{H}, \mathrm{H}^{9}\right), 0.50\left(\mathrm{~s}, 24 \mathrm{H}, \mathrm{H}^{8}\right),-2.87(\mathrm{br}, 2$ $\mathrm{H}, \mathrm{NH}) .{ }^{1} \mathrm{H}$ NMR (thf- $\left.d_{8}\right): \delta=8.84\left(\mathrm{~s}, 8 \mathrm{H}, \mathrm{H}^{1}\right), 8.22\left(\mathrm{~d}, J_{\mathrm{HH}}=\right.$ $\left.7.8 \mathrm{~Hz}, 8 \mathrm{H}, \mathrm{H}^{5}\right), 7.95\left(\mathrm{~d}, J_{\mathrm{HH}}=7.8 \mathrm{~Hz}, 8 \mathrm{H}, \mathrm{H}^{6}\right), 3.58\left(\mathrm{t}, J_{\mathrm{HH}}=\right.$ $\left.6.2 \mathrm{~Hz}, 8 \mathrm{H}, \mathrm{H}^{11}\right), 1.64\left(\mathrm{~m}, 8 \mathrm{H}, \mathrm{H}^{10}\right), 1.03\left(\mathrm{~m}, 8 \mathrm{H}, \mathrm{H}^{9}\right), 0.52(\mathrm{~s}$, $\left.24 \mathrm{H}, \mathrm{H}^{8}\right) .{ }^{13} \mathrm{C}\left\{{ }^{1} \mathrm{H}\right\}$ NMR (thf- $\left.d_{8}\right): \delta=143.6\left(4 \mathrm{C}^{7}\right), 139.4\left(4 \mathrm{C}^{4}\right)$, $134.8\left(8 \mathrm{C}^{6}\right), 132.7\left(8 \mathrm{C}^{5}\right), 131.7\left(\mathrm{br}, 8 \mathrm{C}^{1}\right), 120.9\left(4 \mathrm{C}^{3}\right), 65.5$ $\left(4 \mathrm{C}^{11}\right), 28.5\left(4 \mathrm{C}^{10}\right), 12.5\left(4 \mathrm{C}^{9}\right),-2.8\left(8 \mathrm{C}^{8}\right) .{ }^{29} \mathrm{Si}\left\{{ }^{1} \mathrm{H}\right\} \mathrm{NMR}$ $\left(\right.$ dmso- $\left.d_{6}\right): \delta-2.0 .{ }^{29} \mathrm{Si}\left\{{ }^{1} \mathrm{H}\right\}$ NMR (thf- $\left.d_{8}\right): \delta=-4.0$. ESI-TOF: $m / z=1079.60[\mathrm{M}+\mathrm{H}]^{+}$(calcd 1079.52). Anal. calcd for $\mathrm{C}_{64} \mathrm{H}_{78} \mathrm{~N}_{4} \mathrm{O}_{4} \mathrm{Si}_{4} \cdot \operatorname{thf}(1150.57): \mathrm{C}, 70.91 ; \mathrm{H}, 7.53 ; \mathrm{H}, 4.86$. Found: C, 70.63; H, 7.65; N, 4.98 .

\section{meso-Tetrakis[4-methyldi(3-hydroxypropyl)silylphenyl]- porphyrin (5b)}

To $\left[\mathrm{BH}_{3} \cdot \mathrm{SMe}_{2}\right](2.0 \mathrm{M}, 2.00 \mathrm{mmol}, 1.00 \mathrm{~mL})$ dissolved in thf $(5.0 \mathrm{~mL})$, porphyrin $3 \mathrm{c}(0.207 \mathrm{mmol}, 0.230 \mathrm{~g})$ in thf $(30 \mathrm{~mL})$ was added drop-wise over $10 \mathrm{~min}$ at $0{ }^{\circ} \mathrm{C}$. After $2 \mathrm{~h}$ of stirring at this temperature aqueous $\mathrm{NaOH}(3 \mathrm{M}, 0.75 \mathrm{~mL})$ was added and stirring was continued for $15 \mathrm{~min}$. Afterwards, $\mathrm{H}_{2} \mathrm{O}_{2}(30 \%$, $0.75 \mathrm{~mL}$ ) was added in a single portion and the appropriate reaction mixture was stirred at ambient temperature for $30 \mathrm{~min}$. It was extracted with saturated aqueous $\mathrm{K}_{2} \mathrm{CO}_{3}(20 \mathrm{~mL})$ and then with a $\mathrm{Et}_{2} \mathrm{O}$-thf mixture (ratio $1: 1, \mathrm{v} / \mathrm{v} ; 50 \mathrm{~mL}$ ). The organic layer was washed with brine and filtered through silica gel (thf, column size $1 \times 10 \mathrm{~cm}$ ). All volatiles were removed in oil-pump vacuum and the residue was washed with $\mathrm{Et}_{2} \mathrm{O}(3 \times$ $15 \mathrm{~mL}$ ) and then dried in oil-pump vacuum to give $\mathbf{5 b}$ as a dark red solid ( $0.150 \mathrm{mmol}, 0.186 \mathrm{~g}, 72 \%$ based on 3c).

$\mathrm{Mp}=350{ }^{\circ} \mathrm{C}$ (dec). IR (KBr disc): $\tilde{v}=3393(\mathrm{~s}, \mathrm{OH}), 3314(\mathrm{~s}$, $\mathrm{NH}$ ) 3055, 3011, 2994, 2927, 2863, 1251 (m, $\mathrm{CH}_{3}$ bending), 801 (s, SiC). ${ }^{1} \mathrm{H}$ NMR (dmso- $\left.d_{6}\right): \delta=8.87$ (s, $\left.8 \mathrm{H}, \mathrm{H}^{1}\right), 8.26$ (d, $\left.J_{\mathrm{HH}}=7.5 \mathrm{~Hz}, 8 \mathrm{H}, \mathrm{H}^{5}\right), 7.97\left(\mathrm{~d}, J_{\mathrm{HH}}=7.5 \mathrm{~Hz}, 8 \mathrm{H}, \mathrm{H}^{6}\right), 4.56(\mathrm{t}$, $\left.J_{\mathrm{HH}}=5.3 \mathrm{~Hz}, 8 \mathrm{H}, \mathrm{OH}\right), 3.51\left(\mathrm{q}, J_{\mathrm{HH}}=6.1 \mathrm{~Hz}, 16 \mathrm{H}, \mathrm{H}^{11}\right), 1.67$ $\left(\mathrm{m}, 16 \mathrm{H}, \mathrm{H}^{10}\right), 1.00\left(\mathrm{~m}, 16 \mathrm{H}, \mathrm{H}^{9}\right), 0.51\left(\mathrm{~s}, 12 \mathrm{H}, \mathrm{H}^{8}\right),-2.86(\mathrm{br}$, $2 \mathrm{H}, \mathrm{NH}) .{ }^{1} \mathrm{H}$ NMR (thf- $\left.d_{8}\right): \delta=8.84\left(\mathrm{~s}, 8 \mathrm{H}, \mathrm{H}^{1}\right), 8.22\left(\mathrm{~d}, J_{\mathrm{HH}}=\right.$ $\left.7.6 \mathrm{~Hz}, 8 \mathrm{H}, \mathrm{H}^{5}\right), 7.96\left(\mathrm{~d}, J_{\mathrm{HH}}=7.6 \mathrm{~Hz}, 8 \mathrm{H}, \mathrm{H}^{6}\right), 3.58\left(\mathrm{t}, J_{\mathrm{HH}}=\right.$ $\left.6.4 \mathrm{~Hz}, 16 \mathrm{H}, \mathrm{H}^{11}\right), 1.74\left(\mathrm{~m}, 16 \mathrm{H}, \mathrm{H}^{10}\right), 1.06\left(\mathrm{~m}, 16 \mathrm{H}, \mathrm{H}^{9}\right), 0.52$ $\left(\mathrm{s}, 12 \mathrm{H}, \mathrm{H}^{8}\right) \cdot{ }^{13} \mathrm{C}\left\{{ }^{1} \mathrm{H}\right\}$ NMR (thf- $\left.d_{8}\right): \delta=143.5\left(4 \mathrm{C}^{7}\right), 138.6$ $\left(4 \mathrm{C}^{4}\right), 134.8\left(8 \mathrm{C}^{6}\right), 133.1\left(8 \mathrm{C}^{5}\right), 131.7\left(\mathrm{br}, 8 \mathrm{C}^{1}\right), 121.0\left(4 \mathrm{C}^{3}\right)$, $65.6\left(8 \mathrm{C}^{11}\right), 28.5\left(8 \mathrm{C}^{10}\right), 10.9\left(4 \mathrm{C}^{9}\right),-4.8\left(8 \mathrm{C}^{8}\right) .{ }^{29} \mathrm{Si}\left\{{ }^{1} \mathrm{H}\right\} \mathrm{NMR}$ (dmso- $\left.d_{6}\right): \delta=-0.8 .{ }^{29} \mathrm{Si}\left\{{ }^{1} \mathrm{H}\right\}$ NMR (thf- $\left.d_{8}\right): \delta=-0.8$. ESI-TOF: $m / z=1293.70[\mathrm{M}+\mathrm{K}]^{+}$(calcd 1293.58). Anal. calcd for $\mathrm{C}_{72} \mathrm{H}_{94} \mathrm{~N}_{4} \mathrm{O}_{8} \mathrm{Si}_{4} \cdot \mathrm{H}_{2} \mathrm{O}$ (1273.90): C, 67.88; $\mathrm{H}, 7.60 ; \mathrm{N}, 4.40$. Found: C, 67.68; H, 7.65; N, 4.31.

\section{meso-Tetrakis[4-dimethyl(3-hydroxypropyl)silylphenyl]- porphyrinato zinc (6a)}

To 5 a $(0.0926 \mathrm{mmol}, 0.100 \mathrm{~g})$ dissolved in thf $(30 \mathrm{~mL})$ a solution of $\left[\mathrm{Zn}(\mathrm{OAc})_{2} \cdot 2 \mathrm{H}_{2} \mathrm{O}\right](0.185 \mathrm{mmol}, 0.0407 \mathrm{~g})$ in $\mathrm{MeOH}$ $(10 \mathrm{~mL})$ was added in a single portion. The reaction solution was stirred for $2 \mathrm{~h}$ at ambient temperature and afterwards was concentrated in oil-pump vacuum to dryness. The residue was dissolved in thf $(20 \mathrm{~mL})$ and filtered through a pad of silica gel 
(thf) and then all volatiles were removed in oil-pump vacuum. The remaining solid was washed with a $\mathrm{Et}_{2} \mathrm{O}-{ }^{n}$ pentane mixture (ratio 1:4 v/v,(30 mL)) and then dried in oil-pump vacuum to give the title compound as a dark red solid (0.0857 mmol, $0.0980 \mathrm{~g}, 93 \%$ based on 5a).

$\mathrm{Mp}=350{ }^{\circ} \mathrm{C}$ (dec). IR (KBr disc): $\tilde{v}=3398$ (m, OH), 3048, 3004, 2945, 2927, 2863, 1246 (s, $\mathrm{CH}_{3}$ bending), 831, 798 (s, SiC). ${ }^{1} \mathrm{H}$ NMR (dmso- $\left.d_{6}\right): \delta=8.76\left(\mathrm{~s}, 8 \mathrm{H}, \mathrm{H}^{1}\right), 8.16\left(\mathrm{~d}, J_{\mathrm{HH}}=\right.$ $\left.7.5 \mathrm{~Hz}, 8 \mathrm{H}, \mathrm{H}^{5}\right), 7.89\left(\mathrm{~d}, J_{\mathrm{HH}}=7.5 \mathrm{~Hz}, 8 \mathrm{H}, \mathrm{H}^{6}\right), 4.49\left(\mathrm{t}, J_{\mathrm{HH}}=\right.$ $6.2 \mathrm{~Hz}, 4 \mathrm{H}, \mathrm{OH}), 3.46\left(\mathrm{q}, J_{\mathrm{HH}}=6.3 \mathrm{~Hz}, 8 \mathrm{H}, \mathrm{H}^{11}\right), 1.63(\mathrm{~m}, 8 \mathrm{H}$, $\left.\mathrm{H}^{10}\right), 0.92\left(\mathrm{~m}, 8 \mathrm{H}, \mathrm{H}^{9}\right), 0.47\left(\mathrm{~s}, 24 \mathrm{H}, \mathrm{H}^{8}\right) .{ }^{13} \mathrm{C}\left\{{ }^{1} \mathrm{H}\right\}$ NMR (dmso$\left.d_{6}\right): \delta=150.1\left(4 \mathrm{C}^{2}\right), 144.2\left(4 \mathrm{C}^{7}\right), 138.6\left(4 \mathrm{C}^{4}\right), 134.7\left(8 \mathrm{C}^{6}\right)$, $132.6\left(8 \mathrm{C}^{5}\right.$ and $\left.8 \mathrm{C}^{1}\right), 121.2\left(4 \mathrm{C}^{3}\right), 64.8\left(4 \mathrm{C}^{11}\right), 28.2\left(4 \mathrm{C}^{10}\right)$, $12.4\left(4 \mathrm{C}^{9}\right),-1.8\left(8 \mathrm{C}^{8}\right) .{ }^{29} \mathrm{Si}\left\{{ }^{1} \mathrm{H}\right\} \mathrm{NMR}\left(\mathrm{dmso}-d_{6}\right): \delta=-2.1$. ESI-TOF: $m / z=1179.50[\mathrm{M}+\mathrm{K}]^{+}$(calcd 1179.39). Anal. calcd for $\mathrm{C}_{64} \mathrm{H}_{76} \mathrm{~N}_{4} \mathrm{O}_{4} \mathrm{Si}_{4} \mathrm{Zn}$ (1143.04): C, 67.25; H, 6.70; N, 4.90. Found: C, 67.44; H, 7.12; N, 4.81 .

\section{meso-Tetrakis[4-methyldi(3-hydroxypropyl)silylphenyl]- porphyrinato zinc $(6 \mathrm{~b})$}

To porphyrin $5 \mathbf{b}(0.0805 \mathrm{mmol}, 0.100 \mathrm{~g})$ dissolved in thf $(30 \mathrm{~mL}),\left[\mathrm{Zn}(\mathrm{OAc})_{2} \cdot 2 \mathrm{H}_{2} \mathrm{O}\right](0.1611 \mathrm{mmol}, 0.03536 \mathrm{~g})$ in $\mathrm{MeOH}$ $(10 \mathrm{~mL})$ was added in a single portion. The reaction solution was stirred for $2 \mathrm{~h}$ at ambient temperature and afterwards all volatiles were removed in oil-pump vacuum. The obtained residue was dissolved in thf $(50 \mathrm{~mL})$ and filtered through a pad of silica gel (thf). All volatiles were removed in oil-pump vacuum. The remaining residue was washed with $\mathrm{Et}_{2} \mathrm{O}(30 \mathrm{~mL})$ and then dried in oil-pump vacuum to give $\mathbf{6 b}$ as a red solid (0.068 mmol, $0.089 \mathrm{~g}, 85 \%$ based on $\mathbf{5 b}$ ).

$\mathrm{Mp}=350{ }^{\circ} \mathrm{C}$ (dec). IR (KBr disc): $\tilde{v}=3403$ (m, OH), 3055, 3004, 2923, 2863, 1250 (w, $\mathrm{CH}_{3}$ bending), 858, 796 (s, SiC). ${ }^{1} \mathrm{H}$ NMR (dmso- $\left.d_{6}\right): \delta=8.77\left(\mathrm{~s}, 8 \mathrm{H}, \mathrm{H}^{1}\right), 8.18\left(\mathrm{~d}, J_{\mathrm{HH}}=7.7 \mathrm{~Hz}, 8 \mathrm{H}\right.$, $\left.\mathrm{H}^{5}\right), 7.90\left(\mathrm{~d}, J_{\mathrm{HH}}=7.7 \mathrm{~Hz}, 8 \mathrm{H}, \mathrm{H}^{6}\right), 4.49\left(\mathrm{t}, J_{\mathrm{HH}}=6.2 \mathrm{~Hz}, 8 \mathrm{H}\right.$, $\mathrm{OH}), 3.46\left(\mathrm{q}, J_{\mathrm{HH}}=6.3 \mathrm{~Hz}, 8 \mathrm{H}, \mathrm{H}^{11}\right), 1.64\left(\mathrm{~m}, 16 \mathrm{H}, \mathrm{H}^{10}\right), 0.95$ $\left(\mathrm{m}, 16 \mathrm{H}, \mathrm{H}^{9}\right), 0.47\left(\mathrm{~s}, 12 \mathrm{H}, \mathrm{H}^{8}\right) .{ }^{13} \mathrm{C}\left\{{ }^{1} \mathrm{H}\right\}$ NMR (dmso- $\left.d_{6}\right): \delta=$ $150.2\left(4 \mathrm{C}^{2}\right), 144.2\left(4 \mathrm{C}^{7}\right), 137.8\left(4 \mathrm{C}^{4}\right), 134.8\left(8 \mathrm{C}^{6}\right), 132.9$ $\left(8 \mathrm{C}^{5}\right), 132.6$ (br, $\left.8 \mathrm{C}^{1}\right), 121.3\left(4 \mathrm{C}^{3}\right), 64.9\left(4 \mathrm{C}^{11}\right), 28.2\left(4 \mathrm{C}^{10}\right)$, $10.8\left(4 \mathrm{C}^{9}\right),-3.8\left(8 \mathrm{C}^{8}\right) .{ }^{29} \mathrm{Si}\left\{{ }^{1} \mathrm{H}\right\} \mathrm{NMR}\left(\mathrm{dmso}^{-} d_{6}\right): \delta=-0.9$. ESI-TOF: $m / z=1355.62[\mathrm{M}+\mathrm{K}]^{+}$(calcd 1355.49). Anal. calcd for $\mathrm{C}_{72} \mathrm{H}_{92} \mathrm{~N}_{4} \mathrm{O}_{8} \mathrm{Si}_{4} \mathrm{Zn}$ (1319.24): C, 65.33; H, 6.95; H, 4.29. Found: C, 64.89; H, 7.11; N, 4.07.

\section{4-[Tris(4-trimethylsilylphenyl)silyl]benzaldehyde (8a)}

The synthetic procedure described for the preparation of $\mathbf{2 b}$ (see earlier) was applied to synthesize 8a: ${ }^{t} \mathrm{BuLi}(1.7 \mathrm{M}$, $13.00 \mathrm{mmol}, 7.70 \mathrm{~mL}$, ${ }^{n}$ pentane), $7 \mathrm{a}$ (6.50 mmol, $\left.4.10 \mathrm{~g}\right)$ in $\mathrm{Et}_{2} \mathrm{O}(70 \mathrm{~mL})$, dimethyl formamide $(19.50 \mathrm{mmol}, 1.43 \mathrm{~g}$, $1.51 \mathrm{~mL})$ in thf $(40 \mathrm{~mL})$ and aqueous $\mathrm{HCl}(3 \mathrm{~N}, 40 \mathrm{~mL})$. After appropriate work-up, $\mathbf{8 a}$ could be isolated as a colorless solid (5.93 mmol, $3.45 \mathrm{~g}, 91 \%$ based on $7 \mathrm{a}$ ).

$\mathrm{Mp}=212^{\circ} \mathrm{C}$. IR (film): $\tilde{v}=3048,2996,2953$ (m), 2894, 2816 (w, CHO), 2722 (w, CHO), 1706 (s, C=O), 1249 (w, $\mathrm{CH}_{3}$ bending), 1133, 838 (s, SiC). ${ }^{1} \mathrm{H}$ NMR $\left(\mathrm{CDCl}_{3}\right): \delta=10.06(\mathrm{~s}, 1 \mathrm{H}$, $\mathrm{CHO}), 7.87\left(\mathrm{brd}, J_{\mathrm{HH}}=8.2 \mathrm{~Hz}, 2 \mathrm{H}, \mathrm{H}^{3}\right), 7.78\left(\mathrm{brd}, J_{\mathrm{HH}}=8.2 \mathrm{~Hz}\right.$, $\left.2 \mathrm{H}, \mathrm{H}^{4}\right), 7.55\left(\mathrm{~s}, 12 \mathrm{H}, \mathrm{H}^{7}\right.$ and $\left.\mathrm{H}^{8}\right), 0.29\left(\mathrm{~s}, 27 \mathrm{H}, \mathrm{H}^{10}\right) .{ }^{13} \mathrm{C}\left\{{ }^{1} \mathrm{H}\right\}$
$\operatorname{NMR}\left(\mathrm{CDCl}_{3}\right): \delta=192.6\left(1 \mathrm{C}^{1}\right), 143.2\left(1 \mathrm{C}^{2}\right), 142.4\left(3 \mathrm{C}^{9}\right), 136.9$ $\left(2 \mathrm{C}^{4}\right), 135.5\left(6 \mathrm{C}^{7}\right), 133.5\left(3 \mathrm{C}^{6}\right), 132.8\left(6 \mathrm{C}^{8}\right), 128.6\left(2 \mathrm{C}^{3}\right)$, $127.8\left(1 \mathrm{C}^{5}\right),-1.2\left(9 \mathrm{C}^{10}\right) .{ }^{29} \mathrm{Si}\left\{{ }^{1} \mathrm{H}\right\}$ NMR $\left(\mathrm{CDCl}_{3}\right): \delta=-14.7$ $\left(1 \mathrm{Si}^{1}\right),-3.9\left(3 \mathrm{Si}^{2}\right)$. ESI-TOF: $m / z=619.24[\mathrm{M}+\mathrm{K}]^{+}$(calcd 619.21). Anal. calcd for $\mathrm{C}_{35} \mathrm{H}_{44} \mathrm{OSi}_{4}$ (581.05): C, 70.28; H, 7.63. Found: C, 70.19; H, 7.45.

\section{4-[Tris-(4-diallylmethylsilylphenyl)silyl]benzaldehyde (8c)}

The same procedure as described for preparing $\mathbf{2} \mathbf{b}$ was applied in the synthesis of $8 \mathrm{c}$ (see above): ${ }^{t} \mathrm{BuLi}(1.7 \mathrm{M}, 6.00 \mathrm{mmol}$, $3.60 \mathrm{~mL},{ }^{n}$ pentane), $7 \mathrm{c}(3.00 \mathrm{mmol}, 2.361 \mathrm{~g})$ in $\mathrm{Et}_{2} \mathrm{O}(40 \mathrm{~mL})$, dimethyl formamide ( $9.00 \mathrm{mmol}, 0.658 \mathrm{~g}, 0.70 \mathrm{~mL}$ ) in thf $(20 \mathrm{~mL})$ and aqueous $\mathrm{HCl}(3 \mathrm{~N}, 25 \mathrm{~mL})$. After appropriate work-up, 8c was isolated as colorless oil (2.46 mmol, $1.81 \mathrm{~g}$, $82 \%$ based on $7 \mathbf{c}$ ).

IR (film): $\tilde{v}=3074$, 3050, 2996, 2969, 2913, 2878, $2819(\mathrm{w}$, CHO), 2725 (w, CHO), 1705 (s, C=O), 1629 (w, C=C), 1252 (w, $\mathrm{CH}_{3}$ bending), 1132, 821 (s, SiC), 802 (s, SiC). ${ }^{1} \mathrm{H}$ NMR $\left(\mathrm{CDCl}_{3}\right)$ : $\delta=10.07$ (s, $1 \mathrm{H}, \mathrm{CHO}), 7.89\left(\mathrm{brd}, J_{\mathrm{HH}}=8.1 \mathrm{~Hz}, 2 \mathrm{H}, \mathrm{H}^{3}\right), 7.77$ $\left(\right.$ brd, $\left.J_{\mathrm{HH}}=8.1 \mathrm{~Hz}, 2 \mathrm{H}, \mathrm{H}^{4}\right), 7.55\left(\mathrm{brs}, 12 \mathrm{H}, \mathrm{H}^{7}\right.$ and $\left.\mathrm{H}^{8}\right), 5.80$ $\left(\mathrm{ddt}, J_{\mathrm{HH}}=16.9 \mathrm{~Hz}, J_{\mathrm{HH}}=10.2 \mathrm{~Hz}, J_{\mathrm{HH}}=8.0 \mathrm{~Hz}, 6 \mathrm{H}, \mathrm{H}^{12}\right.$ ), 4.91 $\left(\mathrm{ddt}, J_{\mathrm{HH}}=16.9 \mathrm{~Hz}, J_{\mathrm{HH}}=2.1 \mathrm{~Hz}, J_{\mathrm{HH}}=1.1 \mathrm{~Hz}, 6 \mathrm{H}\right.$, cis $-\mathrm{H}^{13}$ ), $4.89\left(\mathrm{ddt}, J_{\mathrm{HH}}=10.2 \mathrm{~Hz}, J_{\mathrm{HH}}=2.1 \mathrm{~Hz}, J_{\mathrm{HH}}=1.1 \mathrm{~Hz}, 6 \mathrm{H}\right.$, trans$\left.\mathrm{H}^{13}\right), 1.84\left(\mathrm{brd}, J_{\mathrm{HH}}=8.0 \mathrm{~Hz}, 12 \mathrm{H}, \mathrm{H}^{11}\right), 0.31\left(\mathrm{~s}, 9 \mathrm{H}, \mathrm{H}^{10}\right)$. ${ }^{13} \mathrm{C}\left\{{ }^{1} \mathrm{H}\right\}$ NMR $\left(\mathrm{CDCl}_{3}\right): \delta=192.5\left(1 \mathrm{C}^{1}\right), 142.8\left(1 \mathrm{C}^{2}\right), 139.1$ $\left(3 \mathrm{C}^{9}\right), 137.0\left(1 \mathrm{C}^{5}\right), 136.9\left(2 \mathrm{C}^{4}\right), 135.4\left(6 \mathrm{C}^{8}\right), 134.0\left(6 \mathrm{C}^{12}\right), 133.9$ $\left(3 \mathrm{C}^{6}\right), 133.4\left(6 \mathrm{C}^{7}\right), 128.6\left(2 \mathrm{C}^{3}\right), 113.5\left(6 \mathrm{C}^{13}\right), 23.5\left(6 \mathrm{C}^{11}\right)$, $-3.6\left(3 \mathrm{C}^{10}\right) \cdot{ }^{29} \mathrm{Si}\left\{{ }^{1} \mathrm{H}\right\} \mathrm{NMR}\left(\mathrm{CDCl}_{3}\right): \delta=-14.7\left(1 \mathrm{Si}^{1}\right),-5.7$ $\left(3 \mathrm{Si}^{2}\right)$. ESI-TOF: $m / z=775.01[\mathrm{M}+\mathrm{K}]^{+}$(calcd 775.30). Anal. calcd for $\mathrm{C}_{46} \mathrm{H}_{56} \mathrm{OSi}_{4}$ (737.28): C, 74.94; H, 7.66. Found: C, $74.93 ; \mathrm{H}, 7.77$.

\section{meso-Tetrakis $\{4$-[tris(4-trimethylsilylphenyl)silyl]phenyl\}- porphyrin (9a)}

To 8a (4.00 mmol, $2.324 \mathrm{~g}$ ) and pyrrole (4.00 mmol, $0.268 \mathrm{~g}$, $0.28 \mathrm{~mL})$ dissolved in $\mathrm{CH}_{2} \mathrm{Cl}_{2}(400 \mathrm{~mL}), \quad\left[\mathrm{BF}_{3} \cdot \mathrm{OEt}_{2}\right]$ $(0.400 \mathrm{mmol}, 0.057 \mathrm{~g}, 0.05 \mathrm{~mL})$ was added in a single portion. The reaction solution was stirred for $2 \mathrm{~h}$ and then 2,3-dichloro5,6-dicyanobenzoquinone ( $3.00 \mathrm{mmol}, 0.681 \mathrm{~g}$ ) was added in a single portion and stirring was continued for $1 \mathrm{~h}$. The reaction mixture was washed with saturated $\mathrm{NaHCO}_{3}(40 \mathrm{~mL})$ and afterwards with water $(3 \times 40 \mathrm{~mL})$. The organic layer was filtered through a pad of silica gel and then all volatiles were removed in oil-pump vacuum. The crude product was purified by column chromatography (a) ${ }^{n}$ hexane and (b) 20 vol\% $\mathrm{CH}_{2} \mathrm{Cl}_{2}{ }^{-}{ }^{n}$ hexane. After all volatiles were removed in oil pump vacuum, porphyrin 9a was obtained as a dark red solid (0.256 mmol, $0.643 \mathrm{~g}, 26 \%$ based on 8a).

$\mathrm{Mp}=350{ }^{\circ} \mathrm{C}$ (dec). IR (KBr disc): $\tilde{v}=3315$ (s, NH), 3047, 2995, 2952, 2932, 2894, 1249 (m, $\mathrm{CH}_{3}$ bending), 1133, 847 (s, $\mathrm{SiC}), 839$ (s, SiC), 803. ${ }^{1} \mathrm{H} \mathrm{NMR}\left(\mathrm{CDCl}_{3}\right): \delta=8.94\left(\mathrm{~s}, 8 \mathrm{H}, \mathrm{H}^{1}\right)$, $8.27\left(\mathrm{brd}, J_{\mathrm{HH}}=8.0 \mathrm{~Hz}, 8 \mathrm{H}, \mathrm{H}^{5}\right), 8.02\left(\mathrm{brd}, J_{\mathrm{HH}}=8.0 \mathrm{~Hz}, 8 \mathrm{H}\right.$, $\left.\mathrm{H}^{6}\right), 7.85\left(\mathrm{brd}, J_{\mathrm{HH}}=8.0 \mathrm{~Hz}, 24 \mathrm{H}, \mathrm{H}^{9}\right), 7.70\left(\mathrm{brd}, J_{\mathrm{HH}}=8.0 \mathrm{~Hz}\right.$, $\left.24 \mathrm{H}, \mathrm{H}^{10}\right), 0.36\left(\mathrm{~s}, 108 \mathrm{H}, \mathrm{H}^{12}\right),-2.72(\mathrm{br}, 2 \mathrm{H}, \mathrm{NH}) .{ }^{13} \mathrm{C}\left\{{ }^{1} \mathrm{H}\right\}$ NMR $\left(\mathrm{CDCl}_{3}\right): \delta=143.3\left(4 \mathrm{C}^{4}\right), 142.2\left(12 \mathrm{C}^{11}\right), 135.8\left(24 \mathrm{C}^{10}\right)$, $134.7\left(8 C^{6}\right), 134.6\left(12 C^{8}\right), 134.2\left(8 C^{5}\right), 133.5\left(4 C^{7}\right) 132.9$ 
$\left(24 \mathrm{C}^{9}\right), 120.1\left(4 \mathrm{C}^{3}\right),-1.1\left(36 \mathrm{C}^{12}\right) .{ }^{29} \mathrm{Si}\left\{{ }^{1} \mathrm{H}\right\}$ NMR $\left(\mathrm{CDCl}_{3}\right): \delta=$ $-14.2\left(4 \mathrm{Si}^{1}\right),-4.5\left(12 \mathrm{Si}^{2}\right)$. Anal. calcd for $\mathrm{C}_{152} \mathrm{H}_{182} \mathrm{~N}_{4} \mathrm{Si}_{16}$ (2514.47): C, 72.60; H, 7.30; N, 2.23. Found: C, 72.54; H, 6.93; $\mathrm{N}, 2.13$.

\section{meso-Tetrakis $\{4$-[tris(4-diallylmethylsilylphenyl)silyl]phenyl\}- porphyrin (9c)}

To 8c (1.81 mmol, $1.333 \mathrm{~g}$ ) and pyrrole (1.81 mmol, $0.122 \mathrm{~g}$, $0.13 \mathrm{~mL})$ dissolved in $\mathrm{CH}_{2} \mathrm{Cl}_{2}(180 \mathrm{~mL}),\left[\mathrm{BF}_{3} \cdot \mathrm{OEt}_{2}\right](0.18 \mathrm{mmol}$, $0.026 \mathrm{~g}, 0.02 \mathrm{~mL}$ ) was added in a single portion. The reaction solution was stirred for $2 \mathrm{~h}$ and then 2,3-dichloro-5,6dicyanobenzoquinone (1.36 mmol, $0.308 \mathrm{~g}$ ) was added and stirring was continued for $1 \mathrm{~h}$. The reaction mixture was washed with saturated $\mathrm{NaHCO}_{3}(40 \mathrm{~mL})$ and then with water $(3 \times 40 \mathrm{~mL})$. The organic layer was filtered through a pad of silica gel and afterwards all volatiles were removed in oil-pump vacuum. The crude product was purified by column chromatography (a) ${ }^{n}$ hexane and (b) 20 vol\% $\mathrm{CH}_{2} \mathrm{Cl}_{2}{ }^{-}{ }^{n}$ hexane. After removal of all volatiles in a vacuum, porphyrin 9c was isolated as a dark red solid $(0.143 \mathrm{mmol}$, $0.452 \mathrm{~g}, 32 \%$ based on $8 \mathrm{c})$.

$\mathrm{Mp}=350{ }^{\circ} \mathrm{C}$ (dec). IR ( $\mathrm{KBr}$ disc): $\tilde{v}=3322(\mathrm{~S}, \mathrm{NH}), 3074$, 3050, 2996, 2968, 2954, 2912, 2878, 1630 (m, C=C), 1252 (m, $\mathrm{CH}_{3}$ bending), 1132, 822 (s, SiC), 802 (s, SiC). ${ }^{1} \mathrm{H}$ NMR $\left(\mathrm{CDCl}_{3}\right)$ : $\delta=8.94\left(\mathrm{~s}, 8 \mathrm{H}, \mathrm{H}^{1}\right), 8.28\left(\mathrm{brd}, J_{\mathrm{HH}}=7.6 \mathrm{~Hz}, 8 \mathrm{H}, \mathrm{H}^{5}\right), 7.99$ $\left(\mathrm{brd}, J_{\mathrm{HH}}=7.6 \mathrm{~Hz}, 8 \mathrm{H}, \mathrm{H}^{6}\right), 7.82\left(\mathrm{brd}, J_{\mathrm{HH}}=7.5 \mathrm{~Hz}, 24 \mathrm{H}_{1} \mathrm{H}^{9}\right)$, $7.68\left(\mathrm{brd}, J_{\mathrm{HH}}=7.5 \mathrm{~Hz}, 24 \mathrm{H}, \mathrm{H}^{10}\right), 5.86\left(\mathrm{ddt}, J_{\mathrm{HH}}=17.2 \mathrm{~Hz}\right.$, $\left.J_{\mathrm{HH}}=9.6 \mathrm{~Hz}, J_{\mathrm{HH}}=8.1 \mathrm{~Hz}, 24 \mathrm{H}, \mathrm{H}^{14}\right), 4.95\left(\mathrm{brd}, J_{\mathrm{HH}}=17.2 \mathrm{~Hz}\right.$, $24 \mathrm{H}$, cis $-\mathrm{H}^{15}$ ), 4.93 (brd, $9.6 \mathrm{~Hz}, 24 \mathrm{H}$, trans $-\mathrm{H}^{15}$ ), 1.90 (brd, $\left.8.00 \mathrm{~Hz}, 48 \mathrm{H}, \mathrm{H}^{13}\right), 0.37\left(\mathrm{~s}, 36 \mathrm{H}, \mathrm{H}^{12}\right),-2.75(\mathrm{~s}, 2 \mathrm{H}, \mathrm{NH})$. ${ }^{13} \mathrm{C}\left\{{ }^{1} \mathrm{H}\right\} \operatorname{NMR}\left(\mathrm{CDCl}_{3}\right): \delta=143.4\left(4 \mathrm{C}^{4}\right), 138.9\left(12 \mathrm{C}^{11}\right), 135.7$ $\left(24 \mathrm{C}^{10}\right), 135.0\left(12 \mathrm{C}^{8}\right), 134.8\left(8 \mathrm{C}^{6}\right), 134.3\left(8 \mathrm{C}^{5}\right), 134.2\left(24 \mathrm{C}^{14}\right)$, $133.5\left(24 \mathrm{C}^{9}\right), 133.2\left(4 \mathrm{C}^{7}\right), 120.1\left(4 \mathrm{C}^{3}\right), 114.0\left(24 \mathrm{C}^{15}\right), 21.6$ $\left(24 \mathrm{C}^{13}\right),-5.8\left(24 \mathrm{C}^{12}\right) .{ }^{29} \mathrm{Si}\left\{{ }^{1} \mathrm{H}\right\} \operatorname{NMR}\left(\mathrm{CDCl}_{3}\right): \delta=-14.2\left(4 \mathrm{Si}^{1}\right)$, -5.7 $\left(12 \mathrm{Si}^{2}\right)$. Anal. calcd for $\mathrm{C}_{200} \mathrm{H}_{230} \mathrm{~N}_{4} \mathrm{Si}_{16}$ (3153.39): C, 76.52; H, 7.38, N, 1.78. Found: C, 76.66; H, 7.17; N, 1.23.

\section{meso-Tetrakis $\{4$-[tris(4-trimethylsilylphenyl)silyl]phenyl\}- porphyrinato zinc (10a)}

To 9a $(0.0139 \mathrm{mmol}, 0.0350 \mathrm{~g})$ in $\mathrm{CHCl}_{3}(5 \mathrm{~mL})$, $\left[\mathrm{Zn}(\mathrm{OAc})_{2} \cdot 2 \mathrm{H}_{2} \mathrm{O}\right](0.0347 \mathrm{mmol}, 0.0076 \mathrm{~g})$ in $\mathrm{MeOH}(2.5 \mathrm{~mL})$ was added in a single portion. The reaction solution was stirred for $2 \mathrm{~h}$ at ambient temperature and afterwards was concentrated in oil-pump vacuum to dryness. The residue was extracted with $\mathrm{CHCl}_{3}(10 \mathrm{~mL})$ and then with water $(5 \mathrm{~mL})$. The organic layer was dried over $\mathrm{MgSO}_{4}$ and all volatiles were removed in oil-pump vacuum to afford 10a as a dark red solid (0.0135 mmol, $0.340 \mathrm{~g}, 97 \%$ based on 9a).

$\mathrm{Mp}=350^{\circ} \mathrm{C}$ (dec). IR (KBr disc): $\tilde{v}=3046,2994,2952,2932$, 2893, 1249 ( $\mathrm{m}, \mathrm{CH}_{3}$ bending), 1132, 845 (s, SiC), 839 (s, SiC), 803. ${ }^{1} \mathrm{H} \mathrm{NMR}\left(\mathrm{CDCl}_{3}\right): \delta=9.02\left(\mathrm{~s}, 8 \mathrm{H}, \mathrm{H}^{1}\right), 8.25\left(\mathrm{brd}, J_{\mathrm{HH}}=\right.$ $7.9 \mathrm{~Hz}, 8 \mathrm{H}, \mathrm{H}^{5}$ ), $7.99\left(\mathrm{brd}, J_{\mathrm{HH}}=7.9 \mathrm{~Hz}, 8 \mathrm{H}, \mathrm{H}^{6}\right.$ ), 7.83 (brd, $\left.J_{\mathrm{HH}}=7.8 \mathrm{~Hz}, 24 \mathrm{H}, \mathrm{H}^{9}\right), 7.68\left(\mathrm{brd}, J_{\mathrm{HH}}=7.8 \mathrm{~Hz}, 24 \mathrm{H}, \mathrm{H}^{10}\right.$ ), $0.34\left(\mathrm{~s}, 108 \mathrm{H}, \mathrm{H}^{12}\right) .{ }^{13} \mathrm{C}\left\{{ }^{1} \mathrm{H}\right\} \operatorname{NMR}\left(\mathrm{CDCl}_{3}\right): \delta=150.1\left(8 \mathrm{C}^{2}\right)$, $144.0\left(4 \mathrm{C}^{4}\right), 142.1\left(12 \mathrm{C}^{11}\right), 135.8\left(24 \mathrm{C}^{10}\right), 134.7\left(12 \mathrm{C}^{8}\right), 134.6$ $\left(8 \mathrm{C}^{6}\right), 134.1\left(8 \mathrm{C}^{5}\right), 133.2\left(4 \mathrm{C}^{7}\right), 132.9\left(24 \mathrm{C}^{9}\right), 132.1\left(8 \mathrm{C}^{1}\right)$, $121.1\left(4 \mathrm{C}^{3}\right),-1.1\left(36 \mathrm{C}^{12}\right) .{ }^{29} \mathrm{Si}\left\{{ }^{1} \mathrm{H}\right\}$ NMR $\left(\mathrm{CDCl}_{3}\right): \delta=-14.3$ $\left(4 \mathrm{Si}^{1}\right),-3.9\left(12 \mathrm{Si}^{2}\right)$. Anal. calcd for $\mathrm{C}_{152} \mathrm{H}_{180} \mathrm{~N}_{4} \mathrm{Si}_{16} \mathrm{Zn} \cdot \mathrm{EtOH}$ (2619.02): C, 70.49; H, 7.14; N, 2.14. Found: C, 70.51; H, 6.95; $\mathrm{N}, 1.86$.

\section{meso-Tetrakis\{4-[tris(4-allyldimethylsilylphenyl)silyl]phenyl]- porphyrinato zinc $(\mathbf{1 0 b})$}

To 9b (0.0123 mmol, $0.0350 \mathrm{~g})$ dissolved in $\mathrm{CHCl}_{3}(5 \mathrm{~mL})$, $\left[\mathrm{Zn}(\mathrm{OAc})_{2} \cdot 2 \mathrm{H}_{2} \mathrm{O}\right](0.0308 \mathrm{mmol}, 0.0067 \mathrm{~g})$ in $\mathrm{MeOH}(2.5 \mathrm{~mL})$ was added in a single portion. The reaction solution was stirred for $2 \mathrm{~h}$ at ambient temperature and then all volatiles were removed in oil-pump vacuum. The residue was extracted with $\mathrm{CHCl}_{3}(10 \mathrm{~mL})$ and then with water $(5 \mathrm{~mL})$. The organic layer was dried over $\mathrm{MgSO}_{4}$ and all volatiles were removed in oil-pump vacuum to afford $\mathbf{1 0 b}$ as a dark red solid (0.0118 mmol, $0.336 \mathrm{~g}, 96 \%$ based on $\mathbf{9 b}$ ).

$\mathrm{Mp}=350^{\circ} \mathrm{C}$ (dec). IR ( $\mathrm{KBr}$ disc): $\tilde{v}=3074,3047,2994,2953$, 2912, 1628 (m, C=C), 1249 ( $\mathrm{m}, \mathrm{CH}_{3}$ bending), 1132, 835 (s, $\mathrm{SiC}), 799$ (s, SiC). ${ }^{1} \mathrm{H} \mathrm{NMR}\left(\mathrm{CDCl}_{3}\right): \delta=9.05\left(\mathrm{~s}, 8 \mathrm{H}, \mathrm{H}^{1}\right), 8.29$ $\left(\right.$ brd, $\left.J_{\mathrm{HH}}=8.0 \mathrm{~Hz}, 8 \mathrm{H}, \mathrm{H}^{5}\right), 7.97\left(\mathrm{brd}, J_{\mathrm{HH}}=8.0 \mathrm{~Hz}, 8 \mathrm{H}, \mathrm{H}^{6}\right)$, $7.85\left(\mathrm{brd}, J_{\mathrm{HH}}=8.0 \mathrm{~Hz}, 24 \mathrm{H}, \mathrm{H}^{9}\right), 7.70\left(\mathrm{brd}, J_{\mathrm{HH}}=8.0 \mathrm{~Hz}\right.$, $\left.24 \mathrm{H}, \mathrm{H}^{10}\right), 5.88\left(\mathrm{ddt}, J_{\mathrm{HH}}=16.9 \mathrm{~Hz}, J_{\mathrm{HH}}=10.2 \mathrm{~Hz}, J_{\mathrm{HH}}=\right.$ $\left.8.1 \mathrm{~Hz}, 24 \mathrm{H}, \mathrm{H}^{14}\right), 4.95\left(\mathrm{ddt}, J_{\mathrm{HH}}=16.9 \mathrm{~Hz}, J_{\mathrm{HH}}=2.1 \mathrm{~Hz}, J_{\mathrm{HH}}=\right.$ $1.1 \mathrm{~Hz}$, cis- $\left.\mathrm{H}^{15}\right), 4.92\left(\mathrm{ddt}, J_{\mathrm{HH}}=10.2 \mathrm{~Hz}, J_{\mathrm{HH}}=2.1 \mathrm{~Hz}, J_{\mathrm{HH}}=\right.$ $1.1 \mathrm{~Hz}$, trans $\left.-\mathrm{H}^{15}\right), 1.86\left(\mathrm{dt}, J_{\mathrm{HH}}=8.1 \mathrm{~Hz}, J_{\mathrm{HH}}=1.1 \mathrm{~Hz}, 24 \mathrm{H}\right.$, $\left.\mathrm{H}^{13}\right), 0.38\left(\mathrm{~s}, 72 \mathrm{H}, \mathrm{H}^{12}\right) .{ }^{13} \mathrm{C}\left\{{ }^{1} \mathrm{H}\right\}$ NMR $\left(\mathrm{CDCl}_{3}\right): \delta=150.1$ $\left(8 \mathrm{C}^{2}\right), 144.0\left(4 \mathrm{C}^{4}\right), 140.5\left(12 \mathrm{C}^{11}\right), 135.8\left(24 \mathrm{C}^{10}\right), 134.9\left(12 \mathrm{C}^{8}\right)$, $134.6\left(12 \mathrm{C}^{14}\right.$ and $\left.8 \mathrm{C}^{6}\right), 134.1\left(8 \mathrm{C}^{5}\right), 133.2\left(24 \mathrm{C}^{9}\right), 133.0$ (4 $\left.\mathrm{C}^{7}\right), 132.1\left(8 \mathrm{C}^{1}\right), 121.1\left(4 \mathrm{C}^{3}\right), 113.5\left(12 \mathrm{C}^{15}\right), 23.6\left(12 \mathrm{C}^{13}\right)$, $-3.5\left(24 \mathrm{C}^{12}\right) .{ }^{29} \mathrm{Si}\left\{{ }^{1} \mathrm{H}\right\} \mathrm{NMR}\left(\mathrm{CDCl}_{3}\right): \delta=-14.2\left(4 \mathrm{Si}^{1}\right),-4.5$ $\left(12 \mathrm{Si}^{2}\right)$. Anal. calcd for $\mathrm{C}_{176} \mathrm{H}_{204} \mathrm{~N}_{4} \mathrm{Si}_{16} \mathrm{Zn} \cdot 2 \mathrm{EtOH}$ (2982.26): C, 72.49; H, 7.30, N, 1.88. Found: C, 72.17; H, 7.10; N, 1.67.

\section{meso-Tetrakis $\{4$-[tris(4-diallylmethylsilylphenyl)silyl]phenyl\}- porphyrinato zinc $(10 \mathrm{c})$}

To $9 \mathrm{c}(0.0317 \mathrm{mmol}, 0.100 \mathrm{~g})$ in $\mathrm{CHCl}_{3}(15 \mathrm{~mL})$, a solution of $\left[\mathrm{Zn}(\mathrm{OAc})_{2} \cdot 2 \mathrm{H}_{2} \mathrm{O}\right](0.0793 \mathrm{mmol}, 0.017 \mathrm{~g})$ in $\mathrm{MeOH}(5 \mathrm{~mL})$ was added in a single portion. The reaction solution was stirred for $2 \mathrm{~h}$ at ambient temperature and afterwards all volatiles were removed in oil-pump vacuum. The residue was extracted with $\mathrm{CHCl}_{3}(20 \mathrm{~mL})$ and then with water $(10 \mathrm{~mL})$. The organic layer was dried over $\mathrm{MgSO}_{4}$ and all volatiles were removed in oilpump vacuum to afford 10c $(0.0308 \mathrm{mmol}, 0.099 \mathrm{~g}, 97 \%$ based on 9c).

$\mathrm{Mp}=350{ }^{\circ} \mathrm{C}$ (dec). IR (KBr disc): $\tilde{v}=3074,3050,2994,2968$, 2912, 2878, 1628 (m, C=C), 1252 ( $\mathrm{m}, \mathrm{CH}_{3}$ bending), 1132, 820 (s, SiC), $802(\mathrm{~s}, \mathrm{SiC}) \cdot{ }^{1} \mathrm{H}$ NMR $\left(\mathrm{CDCl}_{3}\right): \delta=9.03\left(\mathrm{~s}, 8 \mathrm{H}, \mathrm{H}^{1}\right)$, $8.27\left(\mathrm{brd}, J_{\mathrm{HH}}=8.0 \mathrm{~Hz}, 8 \mathrm{H}, \mathrm{H}^{5}\right), 7.97\left(\mathrm{brd}, J_{\mathrm{HH}}=8.0 \mathrm{~Hz}, 8 \mathrm{H}\right.$, $\left.\mathrm{H}^{6}\right), 7.82\left(\mathrm{brd}, J_{\mathrm{HH}}=8.0 \mathrm{~Hz}, 24 \mathrm{H}, \mathrm{H}^{9}\right), 7.67\left(\mathrm{brd}, J_{\mathrm{HH}}=8.0 \mathrm{~Hz}\right.$, $\left.24 \mathrm{H}, \mathrm{H}^{10}\right), 5.85\left(\mathrm{ddt}, J_{\mathrm{HH}}=16.9 \mathrm{~Hz}, J_{\mathrm{HH}}=9.6 \mathrm{~Hz}, J_{\mathrm{HH}}=\right.$ $\left.8.1 \mathrm{~Hz}, 24 \mathrm{H}, \mathrm{H}^{14}\right), 4.94\left(\mathrm{ddt}, J_{\mathrm{HH}}=16.9 \mathrm{~Hz}, J_{\mathrm{HH}}=2.1 \mathrm{~Hz}, J_{\mathrm{HH}}=\right.$ $1.0 \mathrm{~Hz}$, cis $-\mathrm{H}^{15}$ ), $4.91\left(\mathrm{ddt}, J_{\mathrm{HH}}=9.9 \mathrm{~Hz}, J_{\mathrm{HH}}=2.1 \mathrm{~Hz}, J_{\mathrm{HH}}=1.0\right.$ $\mathrm{Hz}$, trans $\left.-\mathrm{H}^{15}\right), 1.89$ (brd, $\left.J_{\mathrm{HH}}=8.1 \mathrm{~Hz}, 48 \mathrm{H}, \mathrm{H}^{13}\right), 0.36(\mathrm{~s}, 36$ $\left.\mathrm{H}, \mathrm{H}^{12}\right) .{ }^{13} \mathrm{C}\left\{{ }^{1} \mathrm{H}\right\} \operatorname{NMR}\left(\mathrm{CDCl}_{3}\right): \delta=150.1\left(8 \mathrm{C}^{2}\right), 144.1\left(4 \mathrm{C}^{4}\right)$, $138.8\left(12 \mathrm{C}^{11}\right), 135.7\left(24 \mathrm{C}^{10}\right), 135.1\left(12 \mathrm{C}^{8}\right), 134.6\left(8 \mathrm{C}^{6}\right), 134.2$ $\left(24 \mathrm{C}^{14}\right), 134.1\left(8 \mathrm{C}^{5}\right), 133.5\left(24 \mathrm{C}^{9}\right), 132.9\left(4 \mathrm{C}^{7}\right), 132.1\left(8 \mathrm{C}^{1}\right)$, 
$121.1\left(4 \mathrm{C}^{3}\right), 114.0\left(24 \mathrm{C}^{15}\right), 21.6\left(24 \mathrm{C}^{13}\right),-5.8\left(12 \mathrm{C}^{12}\right) .{ }^{29} \mathrm{Si}$ $\left\{{ }^{1} \mathrm{H}\right\} \mathrm{NMR}\left(\mathrm{CDCl}_{3}\right): \delta=-14.2\left(4 \mathrm{Si}^{1}\right),-5.7\left(12 \mathrm{Si}^{2}\right)$. Anal. calcd for $\mathrm{C}_{200} \mathrm{H}_{228} \mathrm{~N}_{4} \mathrm{Si}_{16} \mathrm{Zn} \cdot 2 \mathrm{EtOH}$ (3294.87): C, 74.36; H, 7.34; N, 1.70. Found: C, 74.21; H, 7.30; N, 1.78.

\section{X-ray crystallography}

Single crystal X-ray diffraction measurements of $\mathbf{3 b}, \mathbf{c}, \mathbf{4 a}$ and 9b were performed with a Bruker Smart 1k CCD diffractometer using Mo $K_{\alpha}$ radiation $(\lambda=0.71073 \AA)$, while for data collection of $\mathbf{6 a}$ an Oxford Gemini $\mathrm{S}$ diffractometer and $\mathrm{Cu} \mathrm{K}_{\alpha}$ radiation $(\lambda=1.54184 \AA)$ was used. Table $\mathrm{S} 1 \uparrow$ summarizes selected crystal and structural refinement data of $\mathbf{3 b}, \mathbf{c}, \mathbf{4 a}, \mathbf{6} \mathbf{a}$ and $\mathbf{9 b}$. All structures were solved by direct methods using the SHELXS-97 and refined by full-matrix least-squares procedures on $F^{2}$ using the SHELXL-97 as part of the software package SHELXTL. ${ }^{46}$ All non-hydrogen atoms were refined anisotropically. All C-, $\mathrm{N}$ - and O-bonded hydrogen atoms were refined using a riding model. Only in the case of $3 \mathbf{c}$ the positions of $\mathrm{N}$-bonded hydrogen atoms could be taken from the difference Fourier map and were refined freely. For $\mathbf{3 b}$ the atoms C52C54 have been refined disordered on three positions with occupation factors of $0.26,0.20$ and 0.54 . Furthermore, the $\mathrm{CH}_{2}$ group of the partially occupied $\mathrm{CH}_{2} \mathrm{Cl}_{2}$ (occupation factor 1/4) packing solvent molecule has been refined to split occupancies of 0.94 and 0.06 . In the case of $3 \mathbf{c}$ the atoms C23-C29 and C30-C36 have been refined disordered with split occupancies of $0.68 / 0.32$ and $0.51 / 0.49$, respectively. In the case of 4a the atoms C38-C42 and C49-C53 have been refined disordered with split occupancies of $0.36 / 0.64$ and $0.72 / 0.28$, respectively. For 6a one thf packing solvent molecule (O6, C70-C73) has been refined disordered with split occupancies of 0.47 and 0.53. Furthermore, atoms $\mathrm{O} 1, \mathrm{O} 2$ and $\mathrm{O} 3$ are disordered and have been refined to split occupancies of $0.54 / 0.46,0.50 / 0.50$ and $0.50 / 0.50$, respectively. In the case of 9b the atoms $\mathrm{C} 25 / \mathrm{C} 26, \mathrm{C} 36 / \mathrm{C} 37$ and $\mathrm{C} 126$ have been disordered with split occupancies of $0.76 / 0.24,0.57 / 0.43$ and $0.52 / 0.48$, respectively. Furthermore, the ethyl group (C11O, C12O) of one partially occupied EtOH molecule (occupation factor $1 / 2$ ) has been refined to split occupancies of 0.32 and 0.68 .

Data have been deposited at the Cambridge Crystallographic Data Centre under the CCDC deposition numbers 976300 (3c), 976301 (3b), 976302 (4a), 976303 (6a) and 976304 (9a).

\section{Acknowledgements}

We gratefully acknowledge the generous financial support from the Deutsche Forschungsgemeinschaft (Research Training Group Accumol, Research Unit "Towards Molecular Spintronics" FOR1154) and the Fonds der Chemischen Industrie. We thank Dipl.-Phys. L. Smykalla and Prof. Dr M. Hietschold (Technische Universität Chemnitz, Faculty of Sciences, Institute of Physics) for providing us with a DFT calculated "saddleshaped" deformed molecular structure of tetra( $p$-hydroxyphenyl) porphyrin (Fig. S7†) and for helpful discussion con- cerning the definition of "saddle-shaped" deformed geometries of porphyrins.

\section{References}

1 (a) S. Svenson and D. A. Tomalia, Adv. Drug Delivery Rev., 2012, 64, 102; (b) D. Astrúc, E. Boisselier and C. Ornelas, Chem. Rev., 2010, 110, 1857; (c) A. Sekiguchi, V. Y. Lee and M. Nanjo, Coord. Chem. Rev., 2000, 210, 11; (d) M. Fischer and F. Vögtle, Angew. Chem., 1999, 111, 934, (Angew. Chem. Int. Ed., 1999, 38, 884); (e) A. W. Bosman, H. M. Janssen and E. W. Meijer, Chem. Rev., 1999, 99, 1665; (f) G. R. Newkome, E. He and C. N. Moorefield, Chem. Rev., 1999, 99, 1689.

2 (a) D. A. Tomalia, Soft Matter, 2010, 6, 456-474; (b) A.-M. Caminade, C.-O. Turrin, R. Laurent, A. Ouali and B. Delavaux-Nicot, Dendrimers: Towards Catalytic, Material and Biomedical Uses, John Wiley \& Sons, Chichester, 2011; (c) D. Türp, T.-T.-T. Nguyen, M. Baumgarten and K. Müllen, New J. Chem., 2012, 36, 282; (d) X. Qi, C. Xue, X. Huang, Y. Huang, X. Zhou, H. Li, D. Liu, F. Boey, Q. Yan, W. Huang, S. De Feyter, K. Müllen and H. Zhang, Adv. Funct. Mater., 2010, 20, 43.

3 A. Carlmark, C. Hawker, A. Hult and M. Malkoch, Chem. Soc. Rev., 2009, 38, 352.

4 (a) S. M. Grayson and J. M. Fréchet, Chem. Rev., 2001, 101, 3819; (b) T. Kawaguchi, K. L. Walker, C. L. Wilkins and J. S. Moore, J. Am. Chem. Soc., 1995, 117, 2159.

5 (a) A. K. Diallo, J. Ruiz and D. Astrúc, Chem.-Eur. J., 2013, 19, 8913; (b) D. Astrúc, Nat. Chem., 2012, 4, 255; (c) X.-N. Han, J.-M. Chen, Z.-T. Huang and Q.-Y. Zheng, Eur. J. Org. Chem., 2012, 6895; (d) G. Bergamini, P. Ceroni, P. Fabbrizi and S. Cicchi, Chem. Commun., 2011, 47, 12780. 6 K. Chiad, M. Grill, M. Baumgarten, M. Klapper and K. Müllen, Macromolecules, 2013, 46, 3554.

7 (a) J. Lim and E. E. Simanek, Adv. Drug Delivery Rev., 2012, 64, 826; $(b)$ A. R. Menjoge, R. M. Kannan and D. A. Tomalia, Drug Discovery Today, 2010, 15, 171; (c) L. G. Weaver, Y. Singh, G. Vamvounis, M. F. Wyatt, P. L. Burn and J. T. Blanchfield, Polym. Chem., 2014, 5, 1173.

8 (a) W. S. Li and T. Aida, Chem. Rev., 2009, 109, 6047; (b) A. Uetomo, M. Kozaki, S. Suzuki, K. Yamanaka, O. Ito and K. Okada, J. Am. Chem. Soc., 2011, 133, 13276; (c) Y.-H. Jeong, H.-J. Yoon and W.-D. Jang, Polym. J., 2012, 44, 512.

9 G. Zaragoza-Galán, M. A. Fowler, J. Duhamel, R. Rein, N. Solladié and E. Rivera, Langmuir, 2012, 28, 11195.

10 (a) M.-S. Choi, T. Yamazaki, I. Yamazaki and T. Aida, Angew. Chem., Int. Ed., 2004, 43, 150; (b) H. Imahori, J. Phys. Chem. B, 2004, 108, 6130; (c) E. M. Harth, S. Hecht, B. Helms, E. E. Malmstrom, J. M. J. Fréchet and C. J. Hawker, J. Am. Chem. Soc., 2002, 124, 3926.

11 (a) M. A. Oar, J. M. Serin, W. R. Dichtel, J. M. J. Fréchet, T. Y. Ohulchanskyy and P. N. Prasad, Chem. Mater., 2005, 17, 2267; (b) A. Zingg, B. Felber, V. Gramlich, L. Fu, 
J. P. Collman and F. Diederich, Helv. Chim. Acta, 2002, 82, 333; (c) J. P. Collman, L. Fu, A. Zingg and F. Diederich, Chem. Commun., 1997, 193.

12 P. Weyermann, J.-P. Gisselbrecht, C. Boudon, F. Diederich and M. Gross, Angew. Chem., Int. Ed., 1999, 38, 3215.

13 (a) P. Bhyrappa, J. K. Young, J. S. Moore and K. S. Suslick, J. Am. Chem. Soc., 1996, 118, 5708; (b) P. Bhyrappa, J. K. Young, J. S. Moore and K. S. Suslick, J. Mol. Catal. A: Chem., 1996, 113, 109.

14 (a) E. R. Gillies and J. M. J. Fréchet, Drug Discovery Today, 2005, 10, 35; (b) N. Nishiyama, H. R. Stapert, G.-D. Zhang, D. Takasu, D.-L. Jiang, T. Nagano, T. Aida and K. Kataoka, Bioconjugate Chem., 2003, 14, 58; (c) G.-D. Zhang, A. Harada, N. Nishiyama, D.-L. Jiang, H. Koyama, T. Aida and K. Kataoka, J. Controlled Release, 2003, 93, 141.

15 W. R. Dichtel, J. M. Serin, C. Edder, J. M. J. Fréchet, M. Matuszewski, L.-S. Tan, T. Y. Ochulchanskyy and P. N. Prasad, J. Am. Chem. Soc., 2004, 126, 5380.

16 (a) E. G. Morales-Espinoza, K. E. Sanchez-Montes, E. Klimova, T. Klimova, I. V. Lijanova, J. L. Maldonado, G. Ramos-Ortíz, S. Hernández-Ortega and M. Martínez-García, Molecules, 2010, 15, 2564; (b) B. P. Singh, R. Vijaya, S. J. Shetty, K. Kandasamy, P. N. Puntambekar and T. S. Srivastava, J. Porphyrins Phthalocyanines, 2000, 4, 659.

17 (a) S.-C. Lo and P. L. Burn, Chem. Rev., 2007, 107, 1097; (b) P. L. Burn, S.-C. Lo and I. D. W. Samuel, Adv. Mater., 2007, 19, 1675; (c) J. M. Lupton, I. D. W. Samuel, M. J. Frampton, R. Beavington and P. L. Burn, Adv. Funct. Mater., 2001, 11, 287; (d) A. Adronov and J. M. J. Fréchet, Chem. Commun., 2000, 1701.

18 (a) V. K. Gupta, A. K. Jain, Z. Ishtaiwi, H. Lang and G. Maheshwari, Talanta, 2007, 73, 803; (b) V. K. Gupta, A. K. Jain, G. Maheshwari, H. Lang and Z. Ishtaiwi, Sens. Actuators, B, 2006, 117, 99.

19 (a) H. Imahori and T. Umeyama, J. Phys. Chem. C, 2009, 113, 9029; (b) V. Balzani, A. Credi and M. Venturi, ChemSusChem., 2008, 1, 26.

20 (a) K. W. Pollak, E. M. Sanford and J. M. J. Fréchet, J. Mater. Chem., 1998, 3, 519; (b) J. S. Lindsey, I. C. Schreiman, H. C. Hsu, P. C. Kearney and A. M. Marguerettaz, J. Org. Chem., 1987, 52, 827.

21 B.-H. Ye and Y. Naruta, Tetrahedron, 2003, 59, 3593.

22 C. J. Murphy and H. W. Post, J. Org. Chem., 1962, 27, 1486.

23 (a) Y. Lee and R. B. Silverman, Org. Lett., 2000, 2, 303; (b) Y. Lee and R. B. Silverman, Tetrahedron, 2001, 57, 5339.

24 Z. Ishtaiwi, T. Rüffer, A. Hildebrandt, F. F. Awwadi, H. Hahn, A. Abylaikhan, D. Taher, U. Siegert, B. Walfort and H. Lang, Eur. J. Inorg. Chem., 2013, 2368.

25 M. Fishwick and M. G. H. Wallbridge, J. Organomet. Chem., 1970, 25, 69.

26 G. Socrates, Infrared Characteristic Group Frequencies, John Wiley \& Sons, 1980, p. 126.

27 A. Nikolić, B. Jović, S. Csanady and S. Petrović, J. Mol. Struct., 2007, 834-836, 249.

28 R. J. Abraham, S. C. M. Fell and K. M. Smith, Org. Magn. Resonance, 1977, 9, 367.
29 K. C. K. Swamy, V. Chandrasekhar, J. J. Harland, J. M. Holmes, R. O. Day and R. R. Holmes, J. Am. Chem. Soc., 1990, 112, 2341.

30 (a) R.-H. Jin, T. Aida and S. Inoue, J. Chem. Soc., Chem. Commun., 1993, 1260; (b) Y. Tomoyose, D.-L. Jiang, R.-H. Jin, T. Aida, T. Yamashita, K. Horie, E. Yashima and Y. Okamoto, Macromolecules, 1996, 29, 5236; (c) R. Sadamoto, N. Tomioko and T. Aida, J. Am. Chem. Soc., 1996, 118, 3978; (d) D. Takasu, N. Tomioka, D.-L. Jiang, T. Aida, T. Kamachi and I. Okura, J. Inorg. Biochem., 1997, 67, 242.

31 K. W. Pollak, J. W. Leon, J. M. J. Fréchet, M. Maskus and H. D. Abruña, Chem. Mater., 1998, 10, 30.

32 (a) S. Kyushin, K. Yoshimura, K. Sato and H. Matsumoto, Chem. Lett., 2009, 38, 324; (b) S. Ishida, M. Ito, H. Horiuchi, H. Hiratsuka, S. Shiraishi and S. Kyushin, Dalton Trans., 2010, 39, 9421.

33 (a) P. C. VanDort and P. L. Fuchs, J. Am. Chem. Soc., 1994, 116, 5657; (b) A. Barbero, Y. Blanco and F. J. Puliolo, J. Org. Chem., 2005, 70, 6876; (c) Z. Ishtaiwi, T. Rüffer, R. Mothes, B. Walfort and H. Lang, J. Organomet. Chem., 2011, 696, 1409.

34 M. O. Sinnokrot, E. F. Valeev and C. D. Sherril, J. Am. Chem. Soc., 2002, 124, 10887.

35 (a) T. Straaso, S. Kapishnikov, K. Kato, M. Takata, J. AlsNielsen and L. Leiserowitz, Cryst. Growth Des., 2011, 11, 3342; (b) D. S. Bohle, E. L. Dodd, A. J. Kosar, L. Sharma, P. W. Stephens, L. Suarez and D. Tazoo, Angew. Chem., Int. Ed., 2011, 50, 6151; (c) K. Yamanishi, M. Miyazawa, T. Yairi, S. Sakai, N. Nishina, Y. Kobori, M. Kondo and F. Uchida, Angew. Chem., Int. Ed., 2011, 50, 6583; (d) T. Amaya, T. Ueda and T. Hirao, Tetrahedron Lett., 2010, 51, 3376; (e) M. J. Gunter, T. P. Jeynes and P. Turner, Eur. J. Org. Chem., 2004, 193; $(f)$ H. M. Lee, M. M. Olmstead, G. G. Gross and A. L. Balch, Cryst. Growth Des., 2003, 3, 691; ( $g$ ) S. Pagola, P. W. Stephens, D. S. Bohle, A. D. Kosov and S. K. Madsen, Nature, 2000, 404, 307; (h) R. G. Khoury, L. Jaquinod, R. Paolesse and K. M. Smith, Tetrahedron, 1999, 55, 6713; (i) M. O. Senge, M. Speck, A. Wiehe, H. Dieks, S. Aguirre and H. Kurreck, Photochem. Photobiol., 1999, 70, 206; (j) H. M. Goff, E. T. Shimomura, Y. Ja Lee and W. R. Scheidt, Inorg. Chem., 1984, 23, 315.

36 (a) D. Bonifazi, G. Accorsi, N. Armaroli, F. Song, A. Palkar, L. Echegoyen, M. Scholl, P. Seiler, B. Jaum and F. Diederich, Helv. Chim. Acta, 2005, 88, 1839; (b) J. Wojaczynski, L. Latos-Grazynski, M. M. Olmstead and A. L. Balch, Inorg. Chem., 1997, 36, 4548.

37 P. Bhyrappa, G. Vaijayanthimala and B. Verghese, Tetrahedron Lett., 2002, 43, 6427.

38 Y. Diskin-Posner, S. Dahal and I. Goldberg, Chem. Commun., 2000, 585.

39 It needs to be emphasized that for $3 \mathbf{b}, 3 \mathbf{c}, \mathbf{4 a}$ and $9 \mathbf{b}, \pi-\pi$ interactions involving the terminal allylic side chains have been left unattended. The allyl groups have been at least partially refined disordered, if possible. Moreover, the respective carbon atoms do have comparatively large $U_{i j}$ values. Due to that it appears less trustworthy to assign for them $\pi-\pi$ interactions correctly apart from attractive van der Waals forces. 
40 (a) Labelling code: symmetry generated equivalent atoms of Si10, Si11-Si16/C101, C102-C188 are assigned as Si0\#, Si1\#-Si6\#/C1\# and C2\#-C88\#. Of symmetry generated carbon atoms only selected ones have been labelled. Atom C126 is disordered on two positions of which only one is displayed and labelled with C12A $(b)$ The assignment of symmetry generated atoms is for $\mathbf{9 b}$ more complicated than in conventional cases, as four digits are allowed only when working with crystallographic software. For example, for $9 \mathbf{b B}$ the atomic labelling of atom Si16 is trivial, its symmetry generated equivalent by applying the crystallographically imposed inversion symmetry should be then labelled as Si16A. A second full molecule of $\mathbf{9 b B}$, fully symmetry generated, should then have the atom labelling Si16B and Si16BA. Such a labelling code is not accessible. Therefore, the following restrictions were applied:

9bA: Atoms generated by crystallographically imposed molecular inversion symmetry are labelled with the suffix "A".

9bA: $\left(2^{\text {nd }}\right.$ full molecule)

$\mathbf{1}^{\text {st }}$ half: N1, N2, Si1-Si8 and C1-C83 labelled with the suffix "B"

$2^{\text {nd }}$ half: N1A and N2A labelled as N1AB and N2AB

C1A-C9A labelled as C1B-C9B

Si1A-Si8A and C10A-C83A labelled as Si1'-Si8' and C10'-C83'

9bB: Atoms generated by crystallographically imposed molecular inversion symmetry labelled as follows N3, N4 and Si9 labelled with the suffix "A" Si10-Si16 and C101-C183 labelled as SiO\#-Si6\# and $C 1 \#-C 83 \#$
9bB: (2 $2^{\text {nd }}$ full molecule)

$1^{\text {st }}$ half: N3, N4 and Si9 labelled with suffix "B" C101-C109 labelled as C01B-C09B Si10-Si16 and C110-C183 labelled as SiO+-Si6+ and $\mathrm{C} 10+-\mathrm{C} 83+$

$2^{\text {nd }}$ half: N3A and N4A labelled as N3AB, N4AB Si9A-Si16A and C101A-C183A labelled as Si9--Si6- and C01--C83-

Note: In the case of labels given in Fig. 14 the suffix “-" has been changed to " $\$$ "

41 W. Jentzen, M. C. Simpson, J. D. Hobbs, X. Song, T. Ema, N. Y. Nelson, C. J. Medforth, K. M. Smith, M. Veyrat, M. Mazzanti, R. Ramasseul, J.-C. Marchon, T. Takeuchi, W. A. Goddard, III and J. A. Shelnutt, J. Am. Chem. Soc., 1995, 117, 11085.

42 W. R. Scheidt, J. U. Mondal, C. W. Eigenbrot, A. Adler, L. J. Radonovich and J. L. Hoard, Inorg. Chem., 1986, 25, 795.

43 C. Hu, B. C. Noll, C. E. Schulz and W. R. Scheidt, Inorg. Chem., 2007, 46, 619.

44 M. P. Byrn, C. J. Curtis, Y. Hsiou, S. I. Khan, P. A. Sawin, S. K. Tendick, A. Terzis and C. E. Strouse, J. Am. Chem. Soc., 1993, 115, 9480.

45 H. E. Gottlieb, V. Kotlyar and A. Nudelman, J. Org. Chem., 1997, 62, 7512.

46 G. M. Sheldrick, SHELXTL Version 5.1, An Integrated System for Solving, Refining and Displaying Crystal Structures from Diffraction Data, Siemens Analytical X-ray Instruments, Madison, WI, 1990. 